San Jose State University

SJSU ScholarWorks

Spring 5-2017

\title{
A Comparative Study of Local Municipalities' Implementation and Compliance of Construction Site Controls, as Required by the California Water Quality Control Board, San Francisco Bay Region, Municipal Regional Stormwater National Pollutant Discharge Elimination Systems (NPDES) Permit
}

Maria Begiebing

San Jose State University

Follow this and additional works at: https://scholarworks.sjsu.edu/etd_projects

Part of the Environmental Policy Commons, Policy Design, Analysis, and Evaluation Commons, and the Public Administration Commons

Recommended Citation

Begiebing, Maria, "A Comparative Study of Local Municipalities' Implementation and Compliance of Construction Site Controls, as Required by the California Water Quality Control Board, San Francisco Bay Region, Municipal Regional Stormwater National Pollutant Discharge Elimination Systems (NPDES) Permit" (2017). Master's Projects. 552.

DOI: https://doi.org/10.31979/etd.3w6b-p9mt

https://scholarworks.sjsu.edu/etd_projects/552

This Master's Project is brought to you for free and open access by the Master's Theses and Graduate Research at SJSU ScholarWorks. It has been accepted for inclusion in Master's Projects by an authorized administrator of SJSU ScholarWorks. For more information, please contact scholarworks@sjsu.edu. 
A Comparative Study of Local Municipalities' Implementation and Compliance of Construction Site Controls, as Required by the California Water Quality Control Board, San Francisco Bay Region, Municipal Regional Stormwater National Pollutant Discharge Elimination Systems (NPDES) Permit

by

Maria Begiebing

A Thesis Quality Research Project Submitted in Partial Fulfillment of the

Requirements for the

Masters Degree in

\section{PUBLIC ADMINISTRATION}

Prof. Frances Edwards, Ph.D

Advisor

The Graduate School

San Jose State University

May 2017 


\section{Table of Contents}

Introduction

Literature Review

Methodology

Findings

City of San Jose

City of Oakland

City of Fremont

City of Hayward

City of Sunnyvale

City of Concord

City of Santa Clara

City of Vallejo

City of Berkeley

City of Richmond

City of Daly City

59

City of Mateo

64

City of San Leandro

67

City of Livermore 


\section{List of Tables}

Table1: City of San Jose Legal Authority

Table 2: City of San Jose Construction Violations $2016 \quad 28$

Table 3: City of San Jose Minimum Qualifications 28

Table 4: City of San Jose Questionnaire Results 29

Table 5: City of Oakland Legal Authority 30

Table 6: City of Oakland Construction Violations 2016

Table 7: City of Oakland Minimum Qualifications 33

Table 8: City of Fremont Legal Authority 34

Table 9: City of Fremont Construction Violations 2016

Table 10: City of Fremont Minimum Qualifications 36

Table 11: City of Fremont Questionnaire Results 36

Table 12: City of Hayward Legal Authority 37

Table 13: City of Hayward Construction Violations $2016 \quad 40$

Table 14: City of Hayward Minimum Qualifications 40

Table 15: City of Hayward Questionnaire Results 41

Table 16: City of Sunnyvale Legal Authority 42

Table 17: City of Sunnyvale Construction Violations $2016 \quad 44$

Table 18: City of Sunnyvale Minimum Qualifications 45

Table 19: City of Concord Legal Authority 45

Table 20: City of Concord Construction Violations $2016 \quad 47$

Table 21: City of Concord Minimum Qualifications 48

Table 22: City of Concord Questionnaire Results 48

Table 23: City of Santa Clara Legal Authority 49

Table 24: City of Santa Clara Construction Violations $2016 \quad 50$

Table 25: City of Santa Clara Minimum Qualifications $\quad 51$

Table 26: City of Santa Clara Questionnaire Results $\quad 51$

Table 27: City of Vallejo Legal Authority 53

Table 28: City of Vallejo Construction Violations 2016

Table 29: City of Vallejo Minimum Qualifications 56

Table 30: City of Vallejo Questionnaire Results $\quad 57$

Table 31: City of Berkeley Legal Authority $\quad 58$

Table 32: City of Berkeley Construction Violations $2016 \quad 58$

Table 33: City of Berkeley Minimum Qualifications 58

Table 34: City of Richmond Legal Authority $\quad 59$

Table 35: City of Richmond Construction Violations $2016 \quad 62$

Table 36: City of Richmond Minimum Qualifications $\quad 62$

Table 37: City of Richmond Questionnaire Results $\quad 63$

Table 38: City of Daly City Legal Authority 64

Table 39: City of Daly City Construction Violations $2016 \quad 65$

Table 40: City of Daly City Minimum Qualifications 65

Table 41: City of Daly City Questionnaire Results 66

Table 42: City of San Mateo Legal Authority $\quad 67$ 
Table 43: City of San Mateo Construction Violations 2016

Table 44: City of San Mateo Minimum Qualifications 69

Table 45: City of San Mateo Questionnaire Results 70

Table 46: City of San Leandro Legal Authority 71

Table 47: City of San Leandro Construction Violations 2016

Table 48: City of San Leandro Minimum Qualifications $\quad 74$

Table 49: City of San Leandro Questionnaire Results $\quad 75$

Table 50: City of Livermore Legal Authority 76

Table 51: City of Livermore Construction Violations 2016

Table 52: City of Livermore Minimum Qualifications $\quad 78$

Table 53: Summary of Education Minimum Qualifications $\quad 81$

Table 54: Summary of Education, Experience, and Knowledge Qualifications 81

Table 55: Total Number of Sites

Table 56: Comparison of Inspections and Violations $\quad 84$

Table 57: Summary of Categories with Most Violations 85

Table 58: Number of Construction Related Stormwater Enforcement Actions 86

\section{LIST OF FIGURES}

Figure 1: Logic Model for Construction Inspection Program 20

$\begin{array}{ll}\text { Figure 2: MRP C.6 Requirements } & 23\end{array}$

Figure 3: Data Collected from Annual Report $\quad 24$

Figure 4: Questionnaire Distributed to Authorized Representative 25 


\section{INTRODUCTION}

\section{Research Focus}

The US Environmental Protection Agency (EPA) has programs designed to protect the navigable waters of the United States from urban runoff pollution. One source of polluted runoff regulated by EPA is from construction sites. In support of this effort, the California Regional Water Quality Control Board issued a regional National Pollutant Discharge Elimination System (NPDES) Permit called the Municipal Regional Permit (MRP). The goal of the MRP is to provide consistent regulation of stormwater contaminants across multiple jurisdictions (CRWQCB, 2015).

This research project evaluated the construction inspection programs of fourteen cities located in California's San Francisco Bay Area to determine whether municipalities are meeting regulatory requirements of the MRP. The fourteen cities evaluated include San Jose, Oakland, Fremont, Hayward, Sunnyvale, Concord, Santa Clara, Vallejo, Berkeley, Richmond, Daly City, San Mateo, San Leandro, and Livermore. The fourteen cities were chosen based on largest population of MRP permittees. This research also explored the challenges cities face implementing C.6 Construction Site Control Construction Inspection Programs. Furthermore, this research examined what minimum qualifications are required for the inspectors enforcing the MRP within the Construction Inspection Programs. 


\section{The Problem}

Urban and industrial development dating back to the 1800's has contributed to the increase of pollution and discharge to waterways in the United States. As population continues to increase in the United States, development will further strain stormwater management resources. Construction activities can significantly affect water quality. Construction activities negatively impact the fish and creeks. Water from a storm event will transport contaminants such as sediment, nutrients and chemicals to the nearest storm conveyance system (CSWRCB, 2015). Contaminants from construction sites must be controlled at the source. Construction sites should prevent pollutants from coming in contact with stormwater to prevent transport to creeks, or other surface water bodies. Monitoring construction activities is the federal law but also an extremely local concern.

\section{Regulatory History}

Congress enacted the Federal Water Pollution Control Act (WPCA) in 1948. The WPCA of 1948 was a pioneer law to address water pollution in the United States (WEF, 1997). Over time pollution issues helped jump-start the environmental movement. On June 29, 1969, the Cuyahoga River in Ohio caught on fire due to severe pollution. Also in 1969, the Hudson River had bacteria levels 170 times the safe limit, and the largest fish kill recorded of 26 million fish occurred in Florida. In 1972, two-thirds of the lakes and rivers had become unsafe for swimming and fishing (EPA, 2015). The marketplace could not be used as an adequate check for environmental degradation, so regulation became necessary (Rosenbloom, 2009). 
The WPCA was amended and expanded in 1972 to the Clean Water Act (CWA) as a response to the amount of pollution at the time (EPA, 2015). The main goal of the CWA was to "restore and maintain the chemical, physical, and biological integrity of our nation's waters" and to have "zero discharge of pollutants into navigable waters by 1985, and fishable and swimmable waters by 1983" (WEF, 1997). The amendments to the CWA made it unlawful to discharge any pollutant from a point source to the waters of the United States without a permit (WEF, 1997). The CWA established water quality standards for all contaminants in water bodies, such as streams, rivers, bays, and oceans. The CWA amendments gave the Environmental Protection Agency (EPA) authority to implement pollution control programs and set water quality standards for states.

The EPA defines stormwater as "stormwater runoff, snow melt runoff, and surface water runoff and drainage." Stormwater must be in "any discernable confined, and discrete conveyance, including but not limited to, any pipe, ditch, channel, tunnel, conduit, well, discrete fissure, container, rolling stock, concentrated animal feeding operation, landfill leachate collection system, vessel or other floating craft into which pollutants are or may be discharged" (Craig, 2004).

The National Pollutant Discharge Elimination System (NPDES) permit applies to discharge directly to or through Municipal Separate Storm Sewer Systems (MS4s) that leads to waters of the United States. A facility is not subject to NPDES stormwater regulation if a facility does not discharge to waters of the United States, or if the water percolates to groundwater. The definition according to the EPA's regulation 40 CFR 230.3(s) of waters of the United States is as follows: 
1) All waters that are currently used, were used in the past, or may be susceptible to use in interstate or foreign commerce, including all waters that are subject to the ebb and flow of the tide

2) All interstate waters including interstate wetlands

3) All other waters such as intrastate lakes, rivers, streams (including intermittent streams), mudflats, sand flats, wetlands, sloughs, prairie potholes, wet meadows, playa lakes, or natural ponds the use, degradation, or destruction of which would affect interstate or foreign commerce including such waters: a) That are or could be used by interstate or foreign travelers for recreational or other purposes b) From which fish or shellfish are or could be taken and sold in interstate or foreign commerce or c) That are used or could be used for industrial purposes by industries in interstate commerce

4) All impoundments of waters otherwise defined as waters of the United States under this definition

5) Tributaries of waters

6) The territorial sea

7) Wetlands adjacent to waters

Waters of the United States does not include wastewater treatment plants or converted cropland (Craig, 2004).

Section 401 of the CWA requires that any applicant for federal permit to conduct any activity, including construction that may result in a discharge of a pollutant must obtain a certification. Pollutant is defined in the CWA as "dredged spoil, solid waste, incinerator, residue, filter backwash, sewage, garbage, sewage sludge, munitions, chemical wastes, biological 
materials, radioactive materials, heat, wrecked or discarded equipment, rock, sand, cellar dirt and industrial, municipal, and agricultural waste discharge into water" (Craig, 2004).

Section 402 of the CWA establishes the NPDES permit program, authorized by the CWA since 1972 , to control water pollution by regulating point source discharge pollutants. The CWA made it unlawful to discharge any pollutant from a point source into navigable waters unless a permit is obtained. The EPA's NPDES is designed to control discharges. Point sources are defined in the CWA section 502(14) as "discrete conveyances including but not limited to any pipe, ditch, channel, or conduit from which pollutants are or may be discharged" (Craig, 2004). Municipalities, industrial, and other facilities must obtain a permit to discharge to surface waters (Craig, 2004).

Nationwide Urban Runoff Program (NURP) studies were conducted in the late 1970's to early 1980's. The purpose of the studies was to identify characteristics of stormwater discharge found in municipal conveyances, also known as Municipal Separate Storm Sewer Systems (MS4s). Data from the studies showed that stormwater contained very high levels of pollutants that exceeded water quality standards. The EPA was pressured to focus efforts on non-point discharge to stormwater and require permits for all stormwater discharges. The EPA was unable to operationalize such a requirement because the permit administrative load from the nation would have been too much (Envirocert, 2016).

In 1987, the CWA was expanded to include nonpoint source pollution (James, 2003). Nonpoint pollution sources are generally sources that do not meet the definition of a point source (CRWQB, 2015). Nonpoint source pollution typically results from "land runoff, precipitation, atmospheric, deposition, agricultural drainage, marine/boating operations or hydrologic 
modifications" (CRWQB, 2015). Management of nonpoint source pollution is conducted by either a federal agency, such as the EPA, or left to the states (Craig \& Roberts, 2015).

In 1987, amendments to the CWA outlined an entire section dedicated to stormwater permitting. Section 402(p) outlines five categories of stormwater discharges that represent the largest sources of pollution. The following five categories are also referred to as Phase I facilities:

1) Facilities already covered by an NPDES permit for stormwater

2) Facilities that engage in industrial activity, which includes heavy manufacturing facilities, large construction sites, and transportation facilities

3) Large municipal separate storm drain systems with a population of greater than 250,000

4) Medium population municipal sewer storm drains with a population greater than 100,000 and less than 250,000

5) Facilities that the EPA determines to be significant contributors of pollutants to United States Water (Envirocert, 2016).

Section 402(p) declared that the EPA and states could not require permits for stormwater discharges that do not fall under the five categories listed above until 1992. The intent of Congress was to first focus resources on the largest sources of pollution. Therefore, the EPA held off on permitting any other stormwater discharge besides the five categories until October 1992 (Craig, 2004).

In June 1992, a ruling made by the United States Court of Appeals for the Ninth Circuit provided an exemption from the criteria of stormwater discharges. Exemptions were made for constructions sites smaller than five acres and for "light" industry work. A few months later the 
EPA stated in a memorandum that the further permit consideration on exempt facilities will be revisited (Craig, 2004).

In 1992, the EPA issued two baseline permits. One permit was for industrial dischargers and the other was for construction activities. The baseline permits are used for facilities in states that have the EPA as the main permit implementing authority. Most other states have NPDES permitting authority to establish permit requirements that must be at least as stringent as the baseline established at the federal level by the EPA (Craig, 2004).

In 1995, the EPA addressed those dischargers not originally required to obtain a permit. The dischargers, also known as Phase II dischargers, were notified that they must apply for a permit by August 2001. Phase II dischargers included light industrial facilities, construction sites less than five acres and municipalities with a population of less than 100,000 (Craig, 2004).

In 1995, the EPA began issuing a multi-sector model general permit that covers many industrial categories to group applicants. States with NPDES permitting authority also began issuing multi-sector permits following the EPA's model. The multi-sector permit was modified a few years later and the federal baseline industrial permit was phased out. Those permittees of the industrial general permit were to now find coverage under the multi-sector permit (Craig, 2004).

In 1996 the EPA decided to take an Interim Permitting Approach for Water Quality Based Effluent Limitations. The EPA therefore decided to use a Best Management Practice (BMP) approach rather than numeric limitations in order to reach water quality standards (Craig, 2004).

Construction activities that result in the disturbance of five acres or more of total land area are subject to regulation under Phase I of the NPDES. The EPA felt it necessary to separate construction from light industrial or retail due to construction activity "that disturbs large tracts 
of land will involve the use of heavy equipment such as bulldozers, cranes, and dump trucks and engages in the installation of haul roads, drainage systems and holding ponds" that are often identified with industrial activity. The EPA outlined that the runoff related to construction activities has an immense impact on water quality, especially in regard to sediment among other pollutants. The United States Court of Appeals Ninth Circuit invalidated the NPDES exemption of construction sites less than five acres. The EPA kept the exemption in practice under Phase I but planned to include regulation of construction sites less than five acres under Phase II permitting rules (Envirocert, 2016). Phase II requirements were finalized in 1999.

The EPA Construction General Permit (CPG) is an NPDES general permit issued by the EPA. Most states within the United States issue their own CPG. The EPA CPG permits discharge from construction sites one acre or more or is part of a common plan of development that is equal or greater than one acre. The EPA CPG requires that operators of construction sites implement storm water controls and create a Stormwater Pollution Prevention Plan (SWPPP). States are allowed to take over the permitting program, but the state programs must meet the federal minimum requirements (Envirocert, 2016).

The Porter-Cologne Act is a crucial law used for governing water quality in California. The Porter-Cologne Act applies to surface waters, wetlands, and ground water. The PorterCologne Act declares that: 1) The quality of all waters of the State shall be protected 2) All activities and factors that could affect the quality of the State waters shall be regulated to attain the highest water quality that is reasonable 3) The State must be prepared to exercise its full power and jurisdiction to protect the quality of water in the State from degradation (CSWRCB, 2008). The act also applies to both point and non-point sources of pollution. 


\section{Recent Challenges, San Diego Case Study}

The City of San Diego was fined $\$ 4.6$ million by the San Diego Regional Water Quality Control Board for failure of construction sites control and allowing construction sites to pollute waterways. The Regional Water Board states that the City of San Diego failed to conduct proper inspections and enforce the City's water quality ordinances between Fall 2010 and Spring 2015. The Water Board determined that local water quality ordinances were not enforced because inspectors were poorly trained in erosion control and were unwilling to take enforcement actions (SDRWCB, 2016).

Erosion from construction sites discharges sediment to creeks and other waterways, which transports pollutants and affects water quality. The failure of construction oversight by the City of San Diego led to sediment being transported into the waterways, including the environmentally sensitive Los Peñasquitos Lagoon (SDRWCB, 2016). 


\section{LITERATURE REVIEW}

\section{Why is compliance necessary?}

Literature was examined regarding studies about compliance. Polluted stormwater runoff from construction sites flows through the municipal separate storm sewer system to creeks, rivers, and the bay. Sediment is listed by the EPA as a main pollutant of concern. According to the 2000 National Water Quality Inventory, sediment is reported second after pathogens as one of the most widespread pollutants to water bodies (Pontius, 2008; EPA, 2005). Data from the EPA establishes adverse environmental impacts from construction sites and that stormwater runoff from construction impairs water quality. According to the EPA, sediment runoff rates from construction sites are ten to twenty times greater than agricultural areas and 1,000 to 2,000 greater than forests (Pontius, 2008; EPA, 2005). Construction sites have the ability to discharge more sediment in the brief length of a project than naturally deposited sediment that occurs over decades (Pontius, 2008; EPA, 2005).

The CWA gives the Environmental Protection Agency (EPA) enforcement authority, as well as the States, and authorizes private citizens to file civil cases against those in violation of the CWA (Andreen, 2007). The overlapping enforcement authority was created by Congress to avoid inadequate regulation and hold both layers of government accountable.

Nationally, enforcement budgets have declined over the years. (Andreen, 2007). Although enforcement actions have declined and are infrequent, they are still effective. Research shows that enforced regulations have an important influence on environmental behavior (Shimshack, 2009).

Existing research demonstrates that enforcement, monitoring, conducting inspections and sanctions consistently reduce violations. The sanctions spread to deter violations within industry 
compliance spills over to facilities besides the facility sanctioned, due to the regulator gaining a reputation for enforcement consistence (Shimshack, 2009). Enforcement strategies include educating those being regulated to understand what is compliant behavior (Burby \& Paterson, 1993). A study conducted about deterrence showed that noncompliance by a facility was twice as great if no inspection had occurred during the previous quarter (Magat \& Viscusi, 1990). Larger

fines produce greater change. Agencies must tailor their compliance programs to specific targets and priorities, and be reasonable and fair (Andreen, 2007). More research should be conducted on environmental enforcement and compliance. There is a knowledge gap in regulators' implementation process and cost (Shimshack, 2009).

\section{Implementation}

The goal of permit enforcement is to get the construction industry to comply with NPDES requirements, encourage development of municipal sediment erosion programs, and ensure efficient implementation of the construction stormwater-permitting program to protect water quality (Kabler, 2007). Municipalities develop their stormwater regulations. Municipalities are tasked to develop and implement their own program. All regulated municipalities covered by the Phase II requirements were given five years to develop and fully implement their stormwater management programs (EPA, 2003).

There are provisions in the regulation that allow for streamlined implementation of stormwater programs, such as the qualifying local program provision for management and oversight of stormwater runoff from construction sites (EPA, 2003). The provision increases administrative efficiencies by recognizing local construction programs that meet provisions in the EPA'S CGP. Under the qualifying local program provision, proper NPDES authority, 
including authorized state agencies, can recognize a program that meets or exceeds the

provisions of the CGP (EPA, 2003). Ideally, permitting authorities, such as state agencies, should review potential qualifying local programs and incorporate provisions. Permitting authorities should utilize the annual reporting process, and their role as oversight, to regulate municipal stormwater programs to improve construction programs (EPA, 2003).

\section{Evaluation approach}

The main challenge that the state, regional, municipal governments and the public face is assessing whether stormwater programs are in fact improving water quality. Evaluating effectiveness of programs in meeting public objectives is a fundamental component of state and local government management (White \& Boswell, 2007).

A Stormwater Program Effectiveness Assessment was conducted by The California Stormwater Quality Association (CASQA) (CASQA, 2005). Results of the assessment were published in a CASQA Summary Report. CASQA created a program effectiveness assessment survey to compile information on how agencies were measuring effectiveness. Based on the results from their survey, CASQA developed a guide for evaluating program effectiveness. This research project will follow the analysis portion of the CASQA guide (CASQA, 2005).

Research conducted by White and Boswell was a rare example of literature that examined the planning and implementation of the NPDES Phase II in California and Kansas (White \& Boswell, $2006 \& 2007)$. In the past, cities were able to meet minimum control measures (MCMs) with existing activities in place. Phase II of the NPDES compelled municipalities to adopt new approaches to program management (White \& Boswell, $2006 \&$ 2007). White and Boswell (2007) did not measure effectiveness of stormwater programs but instead focused on local 
government innovation. White and Boswell (2007) concluded that the biggest challenge for municipalities to adopt practices in line with permit requirements is lack of resources. Higher quality stormwater management was found in more populous, wealthy, and more highly educated communities (White \& Boswell, 2006 \& 2007).

Mazmanian and Sabatier have conditions outlined for public managers to evaluate implementation. Although an implementation analysis is not being conducted, there are concepts outlined by Mazmanian and Sabatier that help define the assumptions of the program. According to Mazmanian and Sabatier, implementation is generally defined as the carrying out of a basic policy decision (Mazmanian and Sabatier, 2000). The implementation process begins with statute, followed by policy outputs or decisions by the implementing agencies, the compliance of target groups, the actual impacts of outputs, the perceived impacts of agency decisions, and finally revisions to the statute (Mazmanian and Sabatier, 2000). Mazmanian and Sabatier state that the important role of implementation analysis is to identify the factors that affect the attainment of objectives during the process in its entirety (Mazmanian and Sabatier, 2000). Mazmanian and Sabatier provide key questions to consider that may also be used in an outcome evaluation such as (1) Is the program producing the expected outputs that were planned? (2) Is the program producing its intended short-term outcomes? (3) What differences are there between programs (cities)? (4) What are the areas requiring improvement? These questions are very general and are explored in more specific depth for this research.

The state of Indiana outlines effective evaluations that take place at different stages in the process. A formative process evaluation focuses on administrative indicators of progress. Feedback associated with a formative evaluation for stormwater management includes site visits, quarterly reports, interviews, and plans (Indiana NPS Management Plan, 2008). An outcome 
evaluation usually focuses on administrative indicators or indirect environmental impacts that may or may not be quantified. Feedback associated with an outcome evaluation includes annual report, behavioral changes, and estimation of changes in the environment (Indiana NPS Management Plan, 2008). An impact evaluation uses baseline data to access environmental impacts. Water quality improvement is an example of feedback for impact evaluation (Indiana NPS Management Plan, 2008). Actual results from an evaluation were not published in the literature, rather only a discussion about the evaluation process.

The State Water Resources Control Board (State Water Board) and the Regional Water Quality Control Board created a guidance document for assessing the effectiveness of the municipal stormwater programs and permits. The purpose of the guidance document is to access the effectiveness of the stormwater programs implemented by local municipalities (SWRCB, 2016). Again, actual examples of an evaluation were not in literature, only a focus on the evaluation process. 


\section{METHODOLOGY}

The figure featured below is a logic model for the program that addresses construction site controls. Federal and state laws are included as resources in the logic model because these laws support the purpose of the construction inspection program. Also included in resources is the MRP, because the construction inspection program is structured according to the permit requirements. The activities focus on the actions performed as part of the program and the outputs are results of those actions. For the purpose of this research, this project only focused on short-term outcomes. The long-term outcome goal of improved water quality has too many variables, including programs other than construction inspection, influencing the result. 
Figure 1: Logic Model for Construction Inspection Program

\begin{tabular}{|c|c|c|c|c|c|}
\hline $\begin{array}{l}\text { Resources } \\
\text { We use these } \\
\text { resources } \rightarrow \\
\text { Human, financial, } \\
\text { organizational, \& } \\
\text { Community } \\
\text { Resources }\end{array}$ & Inputs & $\begin{array}{l}\text { Activities } \\
\text { For these } \\
\text { activities } \rightarrow \\
\text { Processes, tools, } \\
\text { events, actions } \\
\text { that are intentional } \\
\text { part of } \\
\text { implementation } \\
\text { This brings } \\
\text { intended change }\end{array}$ & $\begin{array}{l}\text { Outputs } \\
\text { To produce these } \\
\text { outputs } \rightarrow \\
\text { To change } \\
\text { behavior ---- } \rightarrow \\
\text { Direct products of } \\
\text { activities may } \\
\text { include types, } \\
\text { levels \& target of } \\
\text { service }\end{array}$ & \multicolumn{2}{|c|}{$\begin{array}{l}\text { Outcomes } \\
\text { Which leads to these } \\
\text { outcomes }\end{array}$} \\
\hline $\begin{array}{l}\text {-Clean Water Act } \\
\text {-National Pollutant } \\
\text { Discharge } \\
\text { Elimination } \\
\text { System Permit } \\
\text {-Municipal } \\
\text { Regional Permit } \\
\text {-Porter Cologne } \\
\text { Act } \\
\text {-Municipal Codes }\end{array}$ & $\begin{array}{l}\text {-Trained staff } \\
\text {-Department } \\
\text { funds } \\
\text {-Grants } \\
\text {-Rate payers } \\
\text {-Fees }\end{array}$ & $\begin{array}{l}\text {-Track data } \\
\text { relating to MRP } \\
\text { requirements } \\
\text {-Conduct } \\
\text { inspections } \\
\text {-Train staff } \\
\text {-Inspector } \\
\text { education } \\
\text {-Educate target } \\
\text { audience by } \\
\text { providing } \\
\text { factsheets or BMP } \\
\text { material }\end{array}$ & $\begin{array}{l}\text {-Annual report } \\
\text {-Inspections } \\
\text {-Educated Staff } \\
\text {-Educated target } \\
\text { audience }\end{array}$ & $\begin{array}{l}\text { Short } \\
\text {-Compliance } \\
\text { with State } \\
\text { and Federal } \\
\text { law } \\
\text {-Education } \\
\text {-Change in } \\
\text { behavior }\end{array}$ & \begin{tabular}{l|} 
Long \\
-Improved \\
water quality
\end{tabular} \\
\hline
\end{tabular}




\section{Problem Statement}

Traditionally, Municipal Separate Storm Sewer System (MS4) permits were distributed individually to municipalities. Eventually, multi-sector permits were given out to counties. A regional permit was proposed in 2009 and recently distributed to multiple municipalities and counties. Previously, the requirements varied from permit to permit and proved challenging for the Regional Water Board staff to conduct any consistent means of effective evaluation. As of now, municipalities are tasked with the responsibility of determining the effectiveness of their inspections and enforcement activities to prevent polluted construction sites from discharging into storm drains (California Regional Water Quality Control Board, 2015). Now that the Bay Area is on a shared Municipal Regional Permit (MRP) there is an opportunity to evaluate multiple cities with shared requirements.

The key agencies that benefit from the results of the study are the California State Water Resource Board, the Regional Water Board, and the Environmental Protection Agency. The research serves to support the cities in improving their Stormwater Construction Inspection Program. The findings from the research informs agencies such as the State Water Resource Board, the Regional Water Quality Control Board, and the Environmental Protection Agency as to effective best management practices, audits, and reviews regarding the Stormwater Construction Inspection Program. 


\section{Research Questions}

This research aimed to answer the following research question:

What is the current status for each municipality in meeting stormwater goals and NPDES

regulatory requirements?

This research project also examined:

What challenges do municipalities have implementing the requirements of the MRP?

Furthermore, this project explored:

What minimum qualifications are required for Inspectors working in the Construction Inspection Program?

Additionally, each requirement listed in the permit was asked in the form of a question and the reporting provides descriptive data.

\section{Research Design}

A program outcome evaluation was conducted based on the State of Indiana outline of effective evaluation and CASQA effectiveness evaluation guidelines.

Criteria for compliance was established directly from section C.6 of the MRP, see Figure 2 below. 
Figure 2: MRP C.6 Requirements

\begin{tabular}{|c|}
\hline$\underline{\text { Requirements }}$ \\
\hline $\begin{array}{l}\text { Permittees shall have legal authority to require year-round BMPs in the six categories at all } \\
\text { construction sites and have legal authority to inspect and require compliance }\end{array}$ \\
\hline $\begin{array}{l}\text { Permittees shall implement an ERP, a reference document for staff to take consistent action for } \\
\text { effective compliance, that includes enforcement procedures, enforcement tools and field } \\
\text { scenarios, and timely corrections of potential and actual discharges }\end{array}$ \\
\hline $\begin{array}{l}\text { Permittees shall require all construction sites to have BMPs in the following six categories } \\
\text {-Erosion control } \\
\text {-Run-on run-off control } \\
\text {-Sediment Control } \\
\text {-Active Treatment Systems, as necessary } \\
\text {-Good Site Management } \\
\text {-Non-stormwater management }\end{array}$ \\
\hline $\begin{array}{l}\text { Permittees shall review erosion control plans for appropriateness and adequacy of proposed } \\
\text { BMPs for each site before issuing grading permits for a project }\end{array}$ \\
\hline Permittees shall review Stormwater Pollution Prevention Plan (SWPPP) \\
\hline $\begin{array}{l}\text { Permittees shall verify that sites of one acre or more have filed for a Notice of Intent (NOI) for } \\
\text { permit coverage under the Construction General Permit (CGP) }\end{array}$ \\
\hline $\begin{array}{l}\text { Permittees shall provide training or access to training for staff conducting construction stormwater } \\
\text { inspections }\end{array}$ \\
\hline
\end{tabular}

Source: California Regional Water Quality Control Board, 2015. 
Data was collected from the annual report that each municipality prepares, see Figure 3. The data from the annual report was another component to determine whether municipalities are in compliance with MRP.

\section{Figure 3: Data Collected From Annual Report}

\begin{tabular}{|l|}
\hline \multicolumn{1}{|c|}{ Annual Report Data } \\
\hline Number of high priority sites \\
\hline Number of one or more acre sites \\
Number of inspections conducted at one acre or more sites \\
\hline Number of violations and percentage of total in respect to the six categories of best management \\
\hline Number of violations corrected within ten days and percentage of total \\
\hline Number of violations not corrected in 30 days and percentage of total \\
\hline Evaluation of tracking data \\
\hline Evaluation of effectiveness \\
\hline Staff training summary \\
\hline
\end{tabular}

A questionnaire was distributed to authorized representatives of Construction Inspection Programs to collect data about programs, see Figure 4 below. Authorized representatives were initially contacted through a phone call that explained the project, and participation was requested. The questionnaire was then emailed to an authorized representative of the Construction Inspection Program. 
Figure 4: Questionnaire Distributed to Authorized Representative

\begin{tabular}{|l|}
\hline \multicolumn{1}{|c|}{ Questionnaire } \\
\hline Which departments are involved in the issuing, review, and inspection of a grading permit? \\
How many full-time employees (FTEs) are assigned to the Stormwater Construction Inspection \\
Mow many FTEs review erosion control appropriateness and adequacy of proposed Best \\
Employees who review erosion control plans work for which department? \\
\hline Do the employees who review erosion control plans also conduct inspections? \\
\hline Are sites one acre or more verified to have filed an Notice of Intent (NOI) for permit coverage \\
under the Construction General Permit (CGP)? \\
If so, by whom? \\
Are Storm Water Pollution Prevention Plans (SWPPP) reviewed? \\
If so, by whom? \\
\hline Is outreach to developers tracked? \\
\hline Is training provided to Construction Inspection Program employees?
\end{tabular}




\section{FINDINGS}

The goal of the research was to collect a sufficient amount of data to determine whether the municipalities were in compliance with the MRP requirements. An additional component of the research was to determine the standard for inspectors working in the Construction Inspection Program. This research project also aimed to find out what challenges cities have in meeting the requirements.

A requirement of the MRP is that permittees have legal authority to require year-round BMPs at construction sites, and have legal authority to inspect and require compliance. Data collected from the annual report detailing violations in the six BMP categories was examined for each city. Qualitative short answers from the questionnaire provided insight on the influence of the implementation of the program and resources.

The findings from the questionnaire, in addition to the data collected from the annual report and the materials provided from the cities, led to a program evaluation of each municipality to determine compliance and evaluate implementation. 


\section{City of San Jose}

\section{Table 1: City of San Jose Legal Authority}

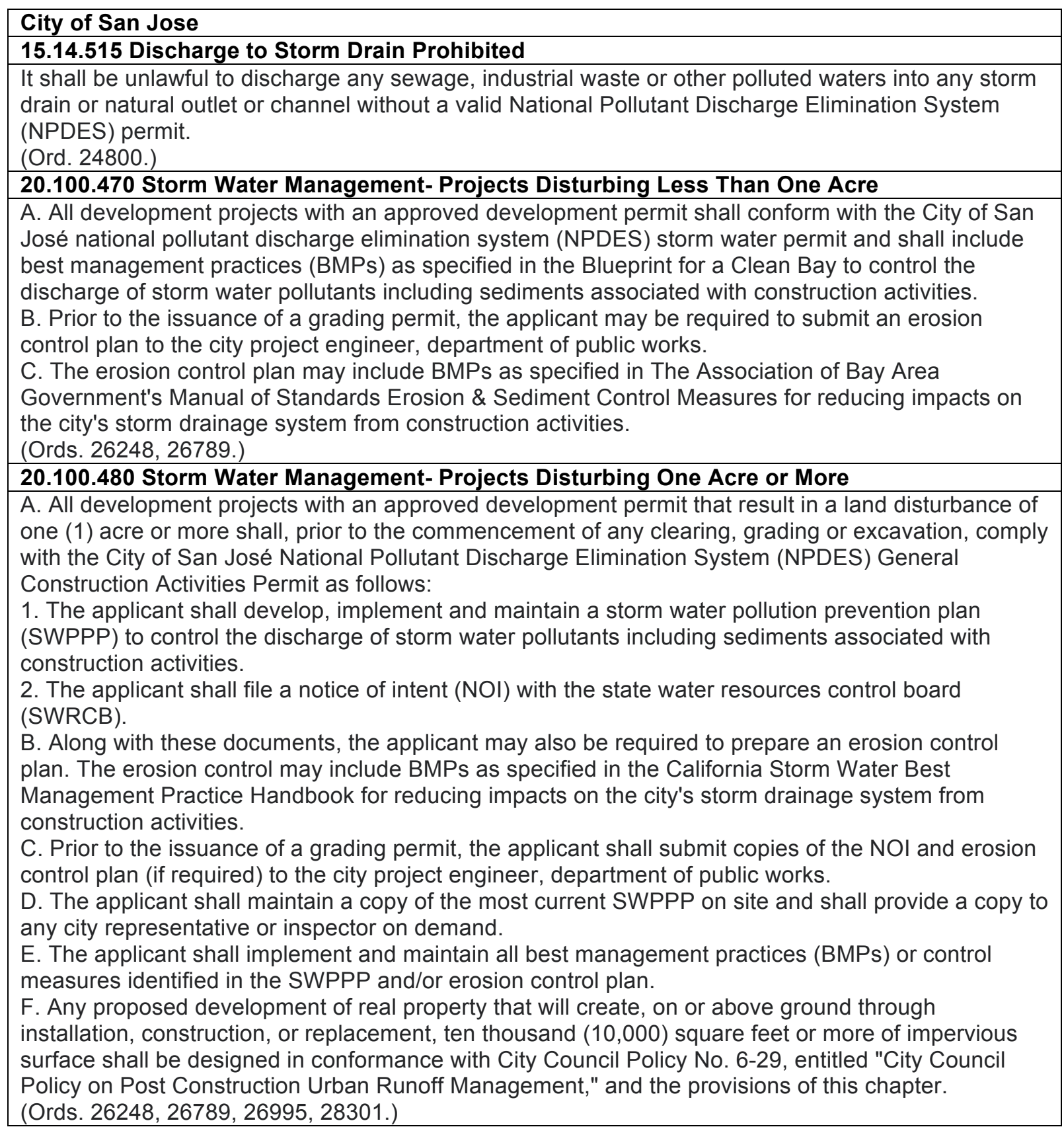

Source: City of San Jose, 2017 
Table 2: City of San Jose Construction Violations for 2016

\begin{tabular}{|l|l|l|}
\hline City of San Jose & Number of Violation & Percentage of Violation \\
\hline BMP Category & & \\
\hline Erosion Control & 12 & $4 \%$ \\
\hline Run-On \& Run Off Control & 0 & $0 \%$ \\
\hline Sediment Control & 169 & $51 \%$ \\
\hline Active Treatment Systems & 0 & $0 \%$ \\
\hline Good Site Management & 133 & $40 \%$ \\
\hline Non Stormwater Management & 17 & $5 \%$ \\
\hline Total & 331 & $100 \%$ \\
\hline
\end{tabular}

Source: San Jose, 2016

\section{Table 3: City of San Jose Minimum Qualifications}

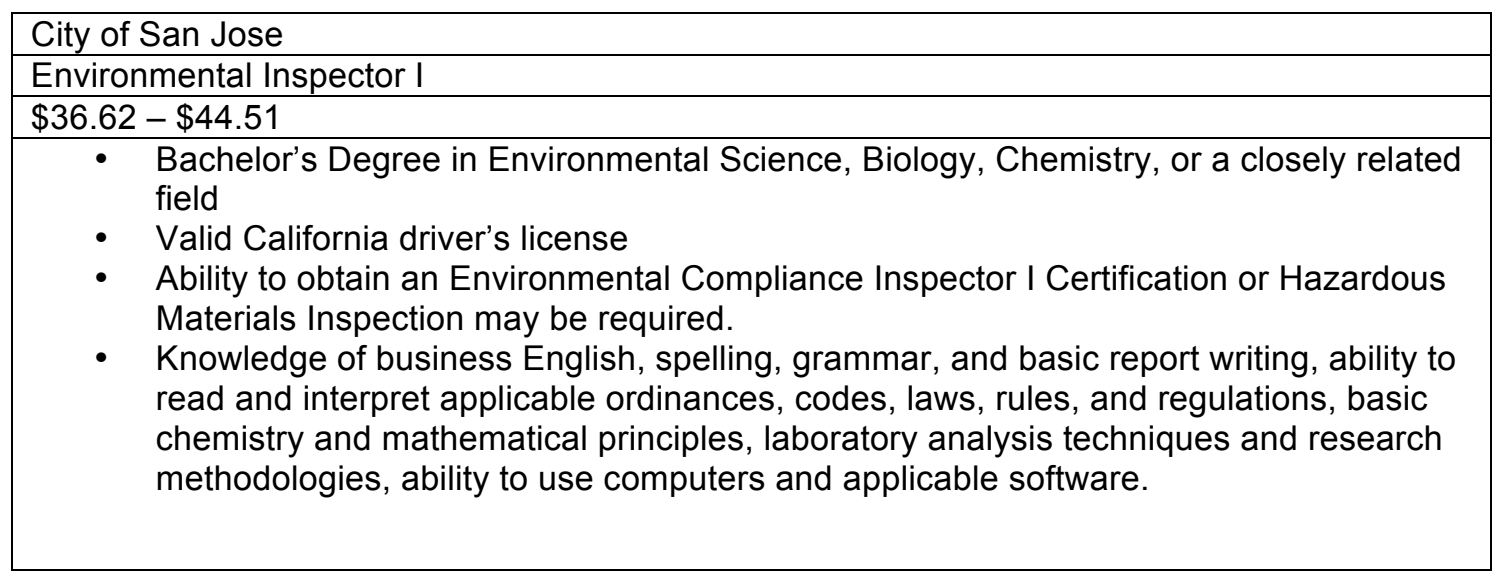

Source: San Jose, 2001 
Table 4: City of San Jose Questionnaire Results

\begin{tabular}{|c|c|}
\hline Questionnaire & City of San Jose \\
\hline $\begin{array}{l}\text { *Please answer questions best to your ability } \\
\text { and interpretation }\end{array}$ & \\
\hline $\begin{array}{l}\text { 1. Which departments are involved in the } \\
\text { issuing, review, and inspection of a grading } \\
\text { permit? }\end{array}$ & Public Works \\
\hline $\begin{array}{l}\text { 2. How many full-time employees (FTEs) are } \\
\text { assigned to the Stormwater Construction } \\
\text { Inspection Program (inspectors enforcing } \\
\text { C.6)? }\end{array}$ & 2.5 \\
\hline $\begin{array}{l}\text { 3. How many FTEs review erosion control } \\
\text { appropriateness and adequacy of proposed } \\
\text { Best Management Practices (BMPs) for each } \\
\text { site before issuing grading permits? }\end{array}$ & $\begin{array}{l}\text { Don't know for sure, Public Works and } \\
\text { Stormwater Management }\end{array}$ \\
\hline $\begin{array}{l}\text { 4. Employees who review erosion control } \\
\text { plans work for which department? }\end{array}$ & Public Works \\
\hline $\begin{array}{l}\text { 5. Do the employees who review erosion } \\
\text { control plans also conduct inspections? }\end{array}$ & Not sure, I do not think so \\
\hline $\begin{array}{l}\text { 6. Are site one acre or more verified to have a } \\
\text { Notice of Intent (NOI) for permit coverage } \\
\text { under the Construction General Permit } \\
\text { (CGP)? } \\
\text { If so, by whom? }\end{array}$ & $\begin{array}{l}\text { It is required by the MRP so think Public Works } \\
\text { Planner does it but not sure }\end{array}$ \\
\hline $\begin{array}{l}\text { 7. Are Storm Water Pollution Prevention Plans } \\
\text { (SWPPP) reviewed? } \\
\text { If so, by whom? }\end{array}$ & $\begin{array}{l}\text { By our El sometimes as a toll for us but not a } \\
\text { thorough review } \\
\text { Environmental Inspector and maybe Public } \\
\text { Works does as they look at Erosion Control } \\
\text { Plan }\end{array}$ \\
\hline $\begin{array}{l}\text { 8. Is outreach to developers tracked? } \\
\text { If so, how much outreach was done to } \\
\text { developers in past fiscal year? }\end{array}$ & $\begin{array}{l}\text { Outreach is tracked for construction sites but } \\
\text { not specific developers }\end{array}$ \\
\hline $\begin{array}{l}\text { 9. Is training provided to Construction } \\
\text { Inspection Program employees? } \\
\text { If so how often? }\end{array}$ & $\begin{array}{l}\text { Yes } \\
\text { At least one time a year through SCVURPPP } \\
\text { but also internal at least one time a year }\end{array}$ \\
\hline $\begin{array}{l}\text { What challenges does your program have } \\
\text { implementing MRP requirements? }\end{array}$ & $\begin{array}{l}\text { Tracking all the required data, growth of } \\
\text { construction development in last few years and } \\
\text { City's limited resources makes it hard to keep } \\
\text { up and meet stricter requirements such as } 10 \\
\text { days for compliance }\end{array}$ \\
\hline
\end{tabular}




\title{
City of Oakland
}

\section{Table 5: City of Oakland Legal Authority}

\author{
City of Oakland \\ 13.16.070 Discharge of Pollutants \\ A. Non-storm-water discharges or increase in flow to the city storm sewer system is prohibited. All \\ discharges of material other than storm water must be in compliance with a NPDES permit issued for \\ the discharge (other than NPDES Permit No. CA0029831). \\ $B$. The following non-storm-water discharges are exempt from the prohibition set forth in subsection \\ A of this section: \\ 1. Non-storm-water discharges regulated under an NPDES permit issued to the discharger and \\ administered by the state of California under authority of the U.S. Environmental Protection Agency; \\ provided, that the discharger is in full compliance with all requirements of the permit and other \\ applicable laws or regulations. \\ 2. \\ Non-storm-water discharges from the following activities will not be considered a source of pollutants \\ to waters of the United States when properly managed: water line flushing and other discharges from \\ potable water sources, landscape irrigation and lawn watering, irrigation water, diverted stream flows, \\ rising ground waters, infiltration to separate storm drains, less than one thousand $(1,000)$ gallons per \\ day of uncontaminated pumped ground water, foundation and footing drains, water from crawl space \\ pumps, air conditioning condensation, springs, individual residential car washings, flows from riparian \\ habitats and wetlands, dechlorinated swimming pool discharges or flows from fire fighting, and \\ accordingly are not subject to the prohibition on non-storm-water discharges.
}

(Ord. 12024 § 1 (part), 1997)

\subsubsection{Discharge in Violation of Permit}

Any non-storm-water discharge or increase in flow that would result in or contribute to a violation of NPDES Permit No. CA0029831, and any amendment, revision or reissuance thereof, either separately considered or when combined with other non-storm-water discharges, is prohibited. A copy of said NPDES permit is on file in the Office of the City Clerk. Liability for any such discharge or increase in flow shall be the responsibility of the person(s) causing or responsible for such discharge or increase in flow, and such person(s) shall defend, indemnify and hold harmless the city, its Councilmembers, directors, officers, agents, and/or employees from any and all claims, losses, actions, causes of actions, judgments, penalties, fines, liabilities and expenses (including reasonable attorney's fees), including damage of property or injury to or death of persons occurring or resulting from such violation, in any administrative or judicial action relating to such discharge or increase in flow.

(Ord. $12024 \S 1$ (part), 1997)

\subsubsection{Reduction of Pollutants in Storm Water}

Any person engaged in activities which will or may result in pollutants entering the city storm sewer system shall eliminate such pollutants to the maximum extent practicable. Examples of such activities include, but are not limited to ownership and operation of leaking vehicles and ownership and use of facilities which may be a source of pollutants such as parking lots, gasoline stations, industrial facilities, commercial facilities, stores fronting city streets, etc. The following minimal requirements shall apply:

A. Littering. No person shall throw, deposit, leave, maintain, keep, or permit to be thrown, deposited, placed, left or maintained, any refuse, rubbish, garbage, or other discarded or abandoned objects, articles, and accumulations, in or upon any street, alley, sidewalk, storm drain, inlet, catch basin, conduit or other drainage structure, business place, or upon any public or private lot of land in the city, so that the same might be or become a pollutant, except in lawfully established garbage containers or in lawfully established dumping grounds.

The occupant or tenant, or in the absence of occupant or tenant, the owner, lessee, or proprietor of any real property in the city in front of which there is a paved sidewalk shall maintain said sidewalk free of dirt or litter to the maximum extent practicable. Sweepings from said sidewalk shall not be swept or otherwise made or allowed to go into the gutter or roadway, but shall be disposed of in 
receptacles maintained on said real property as required for the disposal of garbage.

No person shall throw or deposit litter in any fountain, pond, lake, creek or any other body of water in a park or elsewhere within the city.

B. Standard for Parking Lots and Similar Structures. Persons owning or operating a parking lot, gas station pavement or similar structure shall clean those structures as frequently and thoroughly as practicable in a manner that does not result in discharge of pollutants to the city storm sewer system. C. Best Management Practices for New Developments and Redevelopments. Any person or construction contractor performing work in the city shall, at a minimum, provide filter materials at the catch basin to prevent any debris and dirt from flowing into the city's storm sewer system. In addition, any person or construction contractor performing work in the city is subject to all the provisions of Ordinance No. 10446 C.M.S., entitled "Ordinance for Erosion and Sedimentation Control to Supplement Ordinance No. 10312 C.M.S. (Section 15.04.780 of the Oakland Municipal Code) dated January 18, 1983" and to any amendment or revision thereof.

The Chief of Building Services or his or her designee may establish controls on the volume and rate of storm water runoff from new developments and redevelopments as may be appropriate to minimize the discharge and transport of pollutants. The Chief of Building Services or his or her designee may require as a condition of development or redevelopment implementation of continuous or post construction best management practices such as good housekeeping practices or storm water treatment systems.

When required by the Chief of Building Services or his or her designee, best management practices shall be incorporated into required grading plans, erosion and sedimentation control plans, private improvement plans, plans associated with a building permit and subdivision development.

Any person or construction contractor performing work in the city shall ensure that best management practices required by the Chief of Building Services or his or her designee are properly maintained at all times during construction. Best management practices shall be employed as shown on said plans approved by the city, as required on the conditions on a permit, or as directed by the city's field representative.

Where continuous or post construction best management practices or storm water treatment systems have been required by the Chief of Building Services or his or her designee, proper maintenance of watercourse of said continuous or post construction best management practices or said treatment systems employed on a site shall be the responsibility of the property owner or, when applicable, the local homeowner association.

D. Notification of Intent and Compliance with General Permits. Each industrial discharger, discharger associated with construction activity, or other discharger, described in any general storm water permit addressing such non-storm-water discharges or increase in flow, as may be adopted by the U.S. Environmental Protection Agency, the State Water Resources Control Board, or the California Regional Water Quality Control Board, San Francisco Bay Region, shall provide notice of intent, comply with, and undertake all other activities required by any general storm water permit applicable to such non-storm-water discharges or increase in flow.

Each discharger identified in an individual NPDES permit relating to non-storm-water discharges or increase in flow shall comply with and undertake all activities required by such permit.

E. Compliance with Best Management Practices. Where best management practices guidelines or requirements have been adopted by any federal, state of California, regional, and/or city agency with jurisdiction for such adoption, for any activity, operation, or facility which may cause or contribute to storm water pollution or contamination, increase of flow, illicit discharge, and/or discharge of nonstorm water to the storm water system, or watercourses, every person undertaking such activity or operation, or owning or operating such facility shall comply with such guidelines or requirements as such compliance is identified by the Environmental Services Manager.

(Ord. $12024 \S 1$ (part), 1997)

\subsubsection{Authority to Inspect}

Whenever necessary to make an inspection to enforce any of the provisions of this chapter, or whenever the authorized enforcement official has reasonable cause to believe that there exists in any building or upon any premises any condition which constitutes a violation of the provisions of this chapter, the enforcement official may enter such building or premises at all reasonable times to inspect the same or perform any duty imposed upon the enforcement official by this chapter; provided that (i) if such building or premises be occupied, he or she shall first present proper 
credentials and request entry; and (ii) if such building or premises be unoccupied, he or she shall first make a reasonable effort to locate the owner or other persons having charge or control of the building or premises and request entry.

Any such request for entry shall state that the property owner or occupant has the right to refuse entry and that in the event such entry is refused, inspection may be made only upon issuance of an inspection warrant by a duly authorized judicial officer. In the event the owner and/or occupant refuses entry after such request has been made, the enforcement official is empowered to request such inspection warrant from any court of competent jurisdiction to obtain such entry.

Routine or area inspections shall be based upon such reasonable selection processes as may be deemed necessary to carry out the objectives of this chapter, including but not limited to dye testing to determine illicit connections, random sampling and/or sampling or metering in areas with evidence of storm water contamination, illicit discharges, increase in flow, discharge of non-storm water to the storm water system, or similar factors.

Notwithstanding the above, in exigent circumstances, where there is an imminent threat to the public's health or safety, the emergency procedures outlined in Section 13.16.330, Emergency work by the city, shall be followed.

A. Authority to Sample and Establish Sampling Devices. The city shall have the right to establish on any property such devices as are necessary to conduct sampling or metering operations. During all inspections as provided herein, the authorized enforcement official may take any samples deemed necessary to aid in the pursuit of the inquiry or in the recordation of the activities onsite.

B. Notification of Spills. As soon as any person in charge of a facility or responsible for emergency response for a facility has knowledge of any confirmed or unconfirmed release of materials, pollutants or waste which may result in pollutants or non-storm-water discharges entering the city storm sewer system, such person shall take all necessary steps to ensure the discovery and containment and cleanup of such release and shall contact the appropriate state and local regulatory agencies which have jurisdiction. If hazardous materials are involved, the person in charge of a facility or responsible for emergency response for a facility shall contact immediately, as a minimum, the Oakland Fire Department and Alameda County Hazardous Materials Division and other state and local agencies.

In addition, any person with confirmed or unconfirmed knowledge of release of materials which may result in non-storm-water discharges entering the city storm system shall notify the city of the occurrence by telephoning the Environmental Services Manager and confirming the notification by written correspondence to the Environmental Services Manager within twenty-four (24) hours of said occurrence. During non-business hours, such person shall notify the city of the occurrence by contacting the Oakland Fire Department.

C. Requirement to Test or Monitor or Provide Reports. Any authorized enforcement official may request that any person engaged in any activity and/or owning or operating any facility which may cause or contribute to storm water pollution or contamination, illicit discharges, increase in flow, and/or discharge of non-storm water to the storm water system, undertake, at that person's own cost and expense, such monitoring or testing activities and/or analyses and/or furnish such reports and/or documentation as the official may specify. Such reports and/or documentation may include but are not limited to: interpretation of the results of such monitoring activities or tests; description and/or design data or as-built plans for the facility's storm water conveyance system; and/or the facility's waste disposal documentation or records. The burden, including costs, of these activities, analyses and reports shall bear a reasonable relationship to the need for the monitoring, analyses and reports and the benefits to be obtained. The recipient of such request shall undertake and provide the monitoring, analyses, reports and/or documentation requested. Failure to undertake and provide such monitoring, analyses, reports and/or documentation may result in the city undertaking such and assessing a lien against the property as described in Sections 13.16.300, 13.16.310, 13.16.320 and 13.16340 , in addition to other penalties described in this chapter.

(Ord. $12024 \S 1$ (part), 1997)

\subsubsection{Violations Constituting Infractions}

Any person violating or failing to comply with any of the provisions of this chapter may be guilty of an infraction.

(Ord. 12024 § 1 (part), 1997)

\subsubsection{Penalty for Violation}




\begin{abstract}
Any person convicted of an infraction under the provision of this chapter may be punished upon a first conviction by a fine of not more than one hundred dollars $(\$ 100.00)$ and, for a second conviction within a period of one year, by a fine of not more than two hundred dollars $(\$ 200.00)$ and, for a third or any subsequent conviction within a one-year period, by a fine of not more than five hundred dollars $(\$ 500.00)$. Any violation beyond the third conviction within a one-year period may be charged by the City Attorney or the District Attorney as a misdemeanor and the penalty for conviction of the same may be punishable by a fine of not more than one thousand dollars $(\$ 1,000.00)$ or by imprisonment in the County Jail for a period of not more than six months or by both.

(Ord. 12024 § 1 (part), 1997)

13.16.250 Continuing Violation

Unless otherwise provided, a person shall be deemed guilty of a separate offense for each and every day during any portion of which a violation of this chapter is committed, continued or permitted by the person and shall be punishable accordingly as herein provided.

(Ord. $12024 \S 1$ (part), 1997)

\subsubsection{Acts Potentially Resulting in Violation of Federal Clean Water Act and/or Porter-} Cologne Act

Any person who violates any provision of this chapter, any provision of any permit issued pursuant to this chapter, or who discharges waste or wastewater which causes pollution, or who violates any cease and desist order, prohibition, or effluent limitation, may also be in violation of the federal Clean Water Act and/or Porter-Cologne Act and may be subject to the sanctions of those Acts including civil and criminal penalty. Any enforcement action authorized under this article may also include notice to the violator of such potential liability. (Ord. $12024 \S 1$ (part), 1997)
\end{abstract}

Source: Oakland, 2017

\title{
Table 6: City of Oakland Construction Violations for 2016
}

\begin{tabular}{|l|l|l|}
\hline City of Oakland & Number of Violation & Percentage of Violation \\
\hline BMP Category & & \\
\hline Erosion Control & 4 & $33 \%$ \\
\hline Run-On \& Run Off Control & 2 & $17 \%$ \\
\hline Sediment Control & 4 & $33 \% \%$ \\
\hline Active Treatment Systems & 0 & $0 \%$ \\
\hline Good Site Management & 1 & $9 \%$ \\
\hline Non Stormwater Management & 1 & $9 \%$ \\
\hline Total & 12 & $100 \%$ \\
\hline
\end{tabular}

Source: Oakland, 2016

\section{Table 7: City of Oakland Minimum Qualifications}

\begin{tabular}{|l|}
\hline City of Oakland \\
\hline Environmental Program Specialist \\
\hline \$34.56-\$42.44 \\
\hline $\begin{array}{l}\text { - } \\
\text { civil, environmental, or geologic engineering, geology, or related field } \\
\text { - A master's degree will be considered for the replacement of one year of work } \\
\text { experience }\end{array}$ \\
- Proof of continuing education in a hazardous materials management program is highly \\
desirable \\
Two years of environmental site assessment experience which includes field and \\
contract management experience. Familiarity with the structure of governmental \\
agencies is highly desirable \\
Valid Driver's License
\end{tabular}

Source: Oakland, 2014 
The City of Oakland did not submit answers to the questionnaire.

\section{City of Fremont}

\section{Table 8: City of Fremont Legal Authority}

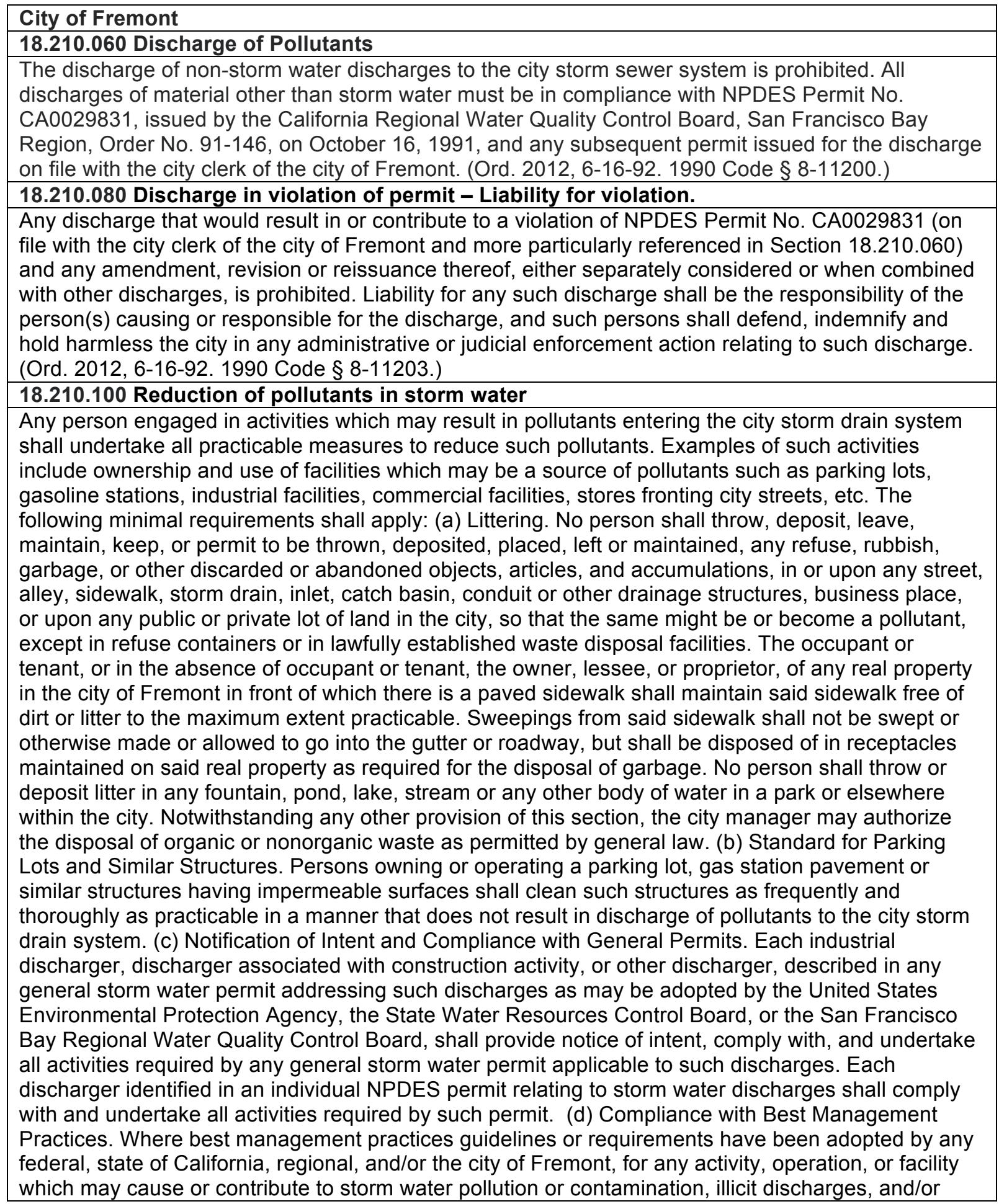


discharge of non-storm water to the storm water system, every person undertaking such activity or operation, or owning or operating such facility, shall comply with such guidelines or requirements as may be prescribed by the city manager. (Ord. 2012, 6-16-92; Ord. 31-2005 § 2, 10-4-05. 1990 Code $\S 8-11205$.

\subsubsection{Authority to Inspect}

(a) Whenever necessary to make an inspection to enforce any of the provisions of this chapter, or whenever any authorized enforcement officer has reasonable cause to believe that there exists in any building or upon any premises any condition which constitutes a violation of the provisions of this chapter, the authorized enforcement officer may enter such building or premises at all reasonable times to inspect the same or perform any duty imposed upon the officer by this chapter; provided, that: (1) if such building or premises be occupied, he/she shall first present proper credentials and request entry; and (2) if such building or premises be unoccupied, he/she shall first make a reasonable effort to locate the owner or other persons having charge or control of the building or premises and request entry. (b) Consent - Search Warrant. Any request for entry by the authorized enforcement officer shall include a statement that the property owner or occupant has the right to refuse entry and that in the event such entry is refused, inspection may be made only upon issuance of a search warrant by a duly authorized magistrate except as permitted for emergency or open space inspections. In the event the owner and/or occupant refuses entry after such request has been made, the authorized enforcement official is hereby empowered to seek assistance from any court of competent jurisdiction in obtaining such entry. (c) Emergency Inspections. In any circumstance where there appears an immediate threat to the public health or safety, any authorized enforcement officer may enter any structure or premises without the consent of any person or court process. (d) Open Space Inspections. In any circumstances when it is necessary for the purposes of investigating or enforcing the provisions of this chapter, any authorized enforcement officer may enter open space areas without forcing entry. Said officer may enter such premises at any time to inspect the same, or to perform any duty imposed by law. (e) Routine or area inspections shall be based upon such reasonable selection processes consistent with general law as may be deemed necessary to carry out the objectives of this chapter, including but not limited to random sampling and/or sampling in areas with evidence of storm water contamination, illicit discharges, discharge of non-storm water to the storm water system, or similar factors. (Ord. 2012, 6-16-92; amended during 2012 reformat. 1990 Code § 8-11301.)

\subsubsection{Acts potentially resulting in violation of federal Clean Water Act and/or Porter-} Cologne Act.

Any person who violates any provision of this chapter, any provision of any permit issued pursuant to this chapter, or who discharges waste or wastewater which causes pollution, or who violates any cease and desist order, prohibition, or effluent limitation, may also be in violation of the federal Clean Water Act and/or Porter-Cologne Act and may be subject to the sanctions of those acts including civil and criminal penalty. Any enforcement action authorized under this article should also include notice to the violator of such potential liability. (Ord. 2012, 6-16-92. 1990 Code § 8-11309.)

Source: Fremont, 2013

\section{Table 9: City of Fremont Construction Violations for $\mathbf{2 0 1 6}$}

\begin{tabular}{|l|l|l|}
\hline City of Fremont & Number of Violation & Percentage of Violation \\
\hline BMP Category & & \\
\hline Erosion Control & 37 & $18 \%$ \\
\hline Run-On \& Run Off Control & 8 & $4 \%$ \\
\hline Sediment Control & 72 & $36 \%$ \\
\hline Active Treatment Systems & 0 & $0 \%$ \\
\hline Good Site Management & 60 & $30 \%$ \\
\hline Non Stormwater Management & 25 & $12 \%$ \\
\hline Total & 202 & $100 \%$ \\
\hline
\end{tabular}

Source: Fremont, 2016 


\title{
Table 10: City of Fremont Minimum Qualifications
}

\author{
City of Fremont \\ Environmental Specialist I \\ $\$ 32.99-\$ 40.10$ \\ - Equivalent to graduation from an accredited college or university with a Bachelor's \\ degree in Environmental Studies, Integrated Waste Management, Environmental \\ Engineering, Public or Business Administration, Geography, Geology, or closely related \\ field \\ - Two years of progressively responsible experience directly related to integrated solid \\ waste management, environmental compliance, or resource conservation, waste \\ reduction and recycling, urban runoff/clean water, hazardous materials management or \\ related field. \\ - Previous lead or supervisory experience is highly desirable \\ - Knowledge of: Principles and industry practices of integrated solid waste management, \\ source reduction, and recycling; clean water program management, general marketing \\ and outreach practices related to environmental programs, principles and practices of \\ contract management, principles and practices of program development and \\ implementation, principles and practices of organization structure and process, team \\ structure and process, principles and practices of business correspondence and report \\ writing, modern office procedures, computer equipment and software, pertinent local, \\ state and federal laws, rules and regulations, and principles and practices of leadership, \\ motivation, team building and conflict resolution.
}

Source: Fremont, 2009

Table 11: City of Fremont Questionnaire Results

\begin{tabular}{|l|l|}
\hline Questionnaire & City of Fremont \\
\hline $\begin{array}{l}\text { *Please answer questions best to your ability } \\
\text { and interpretation }\end{array}$ & \\
\hline $\begin{array}{l}\text { 1. Which departments are involved in the } \\
\text { issuing, review, and inspection of a grading } \\
\text { permit? }\end{array}$ & $\begin{array}{l}\text { Building Inspection, Engineering, } \\
\text { Environmental Services }\end{array}$ \\
\hline $\begin{array}{l}\text { 2. How many full-time employees (FTEs) are } \\
\text { assigned to the Stormwater Construction } \\
\text { Inspection Program (inspectors enforcing } \\
\text { C.6)? }\end{array}$ & 3 \\
\hline $\begin{array}{l}\text { 3. How many FTEs review erosion control } \\
\text { appropriateness and adequacy of proposed } \\
\text { Best Management Practices (BMPs) for each } \\
\text { site before issuing grading permits? }\end{array}$ & 6 \\
\hline $\begin{array}{l}\text { 4. Employees who review erosion control } \\
\text { plans work for which department? }\end{array}$ & $\begin{array}{l}\text { Engineering (with some assistance from } \\
\text { Environmental Services when requested) }\end{array}$ \\
\hline $\begin{array}{l}\text { 5. Do the employees who review erosion } \\
\text { control plans also conduct inspections? }\end{array}$ & $\begin{array}{l}\text { No (except when assistance in review is } \\
\text { requested from Environmental Services) }\end{array}$ \\
\hline 6. Are site one acre or more verified to have a & Yes \\
\hline
\end{tabular}




\begin{tabular}{|c|c|}
\hline $\begin{array}{l}\text { Notice of Intent (NOI) for permit coverage } \\
\text { under the Construction General Permit } \\
\text { (CGP)? } \\
\text { If so, by whom? }\end{array}$ & Engineering \\
\hline $\begin{array}{l}\text { 7. Are Storm Water Pollution Prevention Plans } \\
\text { (SWPPP) reviewed? } \\
\text { If so, by whom? }\end{array}$ & $\begin{array}{l}\text { Generally, yes, but.... } \\
\text {...not until the (Environmental Services) } \\
\text { construction inspector becomes involved (prior } \\
\text { to preconstruction meeting or when project } \\
\text { becomes active) }\end{array}$ \\
\hline $\begin{array}{l}\text { 8. Is outreach to developers tracked? } \\
\text { If so, how much outreach was done to } \\
\text { developers in past fiscal year? }\end{array}$ & $\begin{array}{l}\text { Lists of mailing labels for Pre-Wet Season } \\
\text { Letter are maintained } \\
\text { Pre-wet season letter only }\end{array}$ \\
\hline $\begin{array}{l}\text { 9. Is training provided to Construction } \\
\text { Inspection Program employees? } \\
\text { If so how often? }\end{array}$ & $\begin{array}{l}\text { Yes } \\
\text { Every two years at an absolute minimum, but } \\
\text { generally more than once per year }\end{array}$ \\
\hline $\begin{array}{l}\text { 10. What challenges does your program have } \\
\text { implementing MRP requirements? }\end{array}$ & $\begin{array}{l}\text { Prop } 218 \text { funding constraints, coordination } \\
\text { between departments, inspiring other } \\
\text { departments to "take ownership of" and } \\
\text { prioritize MRP requirements, causing the } \\
\text { business and development community to } \\
\text { prioritize clean water requirements, etc... }\end{array}$ \\
\hline
\end{tabular}

\section{City of Hayward}

\section{Table 12: City of Hayward Legal Authority}

\begin{tabular}{|l|}
\hline City of Hayward \\
\hline 11.5.19 DISCHARGE OF POLLUTANTS \\
\hline The discharge of non-stormwater discharges to the City storm sewer system is prohibited. \\
Prohibited discharges include, but are not limited to polluted cooling water, chlorinated or \\
chlorinated swimming pool water, hazardous or toxic chemicals, grease, animal wastes, \\
detergents, solvents, pesticides, herbicides, fertilizers, and dirt. All discharges of material other \\
than stormwater must be in compliance with a NPDES Permit issued for the discharge other than \\
NPDES Permit No. CA0029831. Exceptions to this prohibition are set forth in subsections (a) and \\
(b) below. (a) NPDES permitted non-stormwater discharges and discharges which are not \\
sources of pollutants to waters of the state (as described in 40 C.F.R. 122.26(d)(2)(iv)(B)(1)) if \\
the discharger is in full compliance with all requirements of the permit and other applicable laws \\
or regulations. Discharges from the following activities will not be considered a source of \\
pollutants to waters of the United States when properly managed in a manner satisfactory to the \\
Director of Public Works: water line flushing or other discharges from potable water sources, \\
landscape irrigation, lawn watering, irrigation water, diverted stream flows, rising ground waters, \\
infiltration to separate storm drains, uncontaminated pumped ground water, foundation and \\
footing drains, water from crawl space pumps, air conditioning condensation, springs, individual \\
residential car washings, flows from riparian habitats and wetlands, dechlorinated swimming pool \\
discharges, or flows from firefighting. \\
Allowable discharges shall not cause any impairment in the beneficial uses or quality of water of the \\
\hline
\end{tabular}


state as defined in the California Water Code or any special requirements of the Regional Water Quality Control Board, San Francisco Bay Region, or injure or interfere with the operation of any watercourses within the State.

\section{1-5.20 - DISCHARGE IN VIOLATION OF PERMIT}

Any discharge that would result in or contribute to a violation of NPDES Permit No. CA0029831, attached to this article as Attachment $\mathrm{A}$, and any amendment or revision thereto, or reissuance thereof, either separately considered or when combined with other discharges, is prohibited. The person causing or responsible for the discharge shall be liable for the discharge, and shall defend, indemnify, and hold the City harmless in any administrative or judicial enforcement action relating to such discharge.

\section{SEC. 11-5.21 - ILLICIT DISCHARGE AND ILLICIT CONNECTIONS}

The establishment, use, maintenance, or continuation of an illicit drainage connection to the City storm sewer system, and the commencement or continuation of any illicit discharges to the City storm sewer system is prohibited. This prohibition is expressly retroactive and applies to connections made in the past, regardless of whether made under a permit or other authorization or whether permissible under the law or practices applicable or in effect at the time of the connection.

\section{1-5.22 - REDUCTION OF POLLUTANTS IN STORMWATER.}

Any person engaged in activities which will or may result in pollutants entering the City storm sewer system shall undertake all practicable measures to reduce such pollutants. Examples of activities that might result in pollutants entering the City storm sewer system include littering and ownership or use of facilities which may be a source of pollutants such as but not limited to parking lots, gasoline stations, industrial facilities, commercial facilities, and stores fronting City streets. The following are minimal requirements applicable to such persons: (a) Littering Prohibited. No person shall throw, deposit, leave, maintain, keep, or permit to be thrown, deposited, placed, left, or maintained, any 'refuse, ' 'rubbish,' 'garbage,' or other discarded or abandoned objects, articles, and accumulations, in or upon any street, alley, sidewalk, storm drain, inlet, catch basin, conduit, or other drainage structures, business place, or upon any public or private lot of land in the City, so that the same might be or become a pollutant. Nor shall any person throw or deposit litter in any fountain, pond, lake, stream, or any other body of water in a park or elsewhere within the City. The occupant or tenant, or in the absence of occupant or tenant, the owner, lessee, or proprietor, of any real property in the City of Hayward that abuts a paved sidewalk shall maintain said sidewalk free of dirt or litter to the maximum extent practicable. Sweepings from said sidewalk shall not be swept or otherwise made or allowed to go into the gutter or roadway, but shall be disposed of in receptacles maintained on said real property as required for the disposal of garbage. (b) Standard of

Maintenance for Parking Lots and Similar Structures. Persons owning or operating a parking lot, a gasoline station, or a similar structure or uses shall clean the property as frequently and thoroughly as practicable in a manner that does not result in discharge of pollutants to the City storm sewer system. (c) Outdoor Storage of Materials. (1) Proper Outdoor Storage of Materials Required. All applicable materials stored outdoors at a commercial or industrial establishment shall be managed in a manner that minimizes the discharge of pollutants to stormwater. Establishments covered by the General Industrial NPDES Permit promulgated by the California Regional Water Quality Control Board, San Francisco Bay Region for stormwater discharges associated with industrial activities, excluding construction activities, shall address this requirement in applicable provisions of their Stormwater Pollution Prevention Plans (SWPPPs). (2) Protection Against Accidental Discharge. Each property owner, its administrators, lessees/tenants, or successors, or any other persons in possession or control of the property who store applicable materials outdoors at a commercial or industrial establishment shall provide protection against the accidental discharge of prohibited materials to the City's storm sewer system or watercourse. Such protection may include, but is not limited to, secondary containment systems or any equivalent protective measures. Any secondary containment system that includes the permanent modification of a building or site, or the addition of a building or structure, shall be submitted to the City's Planning Division and Building Division for approval in accordance with applicable codes. All facilities necessary to prevent the accidental discharge of prohibited materials to the City's storm sewer system or watercourse shall be provided and maintained at the property owner's or operator's expense. (3) Report of Accidental Discharge to the Storm Drain. The property owner, its administrators, successors, or any other persons shall 
notify the City of any accidental discharge to the City's storm sewer system or watercourse as described in Section11-5.26_of this Code. (4) Posted Notice. A notice advising employees of the requirements of Section 11-5.26_and the telephone number to call in case of such an accidental discharge shall be permanently posted in a conspicuous place on the premises of each commercial or industrial establishment.

\section{SEC. 11-5.24 - AUTHORITY TO INSPECT}

Whenever necessary to make an inspection to enforce any of the provisions of this article, or whenever an Authorized Enforcement Official has reasonable cause to believe that there exists in any building or upon any premises any condition which constitutes a violation of the provisions of this article, the official may enter such building or premises at all reasonable times to inspect the same or perform any duty imposed upon the official by this article; provided that (1) if such building or premises be occupied, he or she shall first present proper credentials and request entry; and (2) if such building or premises be unoccupied, he or she shall first make a reasonable effort to locate the owner or other persons having charge or control of the building or premises and request entry. Any such request for entry shall state that the property owner or occupant has the right to refuse entry and that in the event such entry is refused inspection may be made only upon issuance of a search warrant by a duly authorized magistrate. In the event the owner or occupant refuses entry after such request has been made, the official is hereby empowered to seek assistance from any court of competent jurisdiction in obtaining such entry. Routine or area inspections shall be based upon such reasonable selection processes as may be deemed necessary by the Authorized Enforcement Official to carry out the objectives of this article, including but not limited to random sampling and/or sampling in areas with evidence of stormwater contamination, illicit discharges, discharge of non-stormwater to the stormwater system, or similar factors.

\section{1-5.32 Acts Potentially Resulting in Violation of Federal Clean Water Act or State Law}

Any person who violates any provision of this article, or any provision of any permit issued pursuant to this article, or who discharges waste or wastewater which causes pollution, or who violates any cease and desist order, prohibition, or effluent limitation, may also be in violation of the federal Clean Water Act and state law, including the Porter-Cologne Act, and may be subject to the sanctions of those laws including civil and criminal penalty. Any enforcement action authorized under this article shall also include notice to the violator of such potential liability.

\section{1-5.35 Administrative Enforcement Powers}

In addition to the other enforcement powers and remedies established by this article, any Authorized Enforcement Official has the authority to utilize the administrative remedies set forth below. (a) Cease and Desist Orders. When an Authorized Enforcement Official finds that a discharge has taken place or is likely to take place in violation of this article, the official may issue an order to cease and desist such discharge, or practice, or operation likely to cause such discharge and direct that those persons not complying shall: (1) comply with the requirement; (2) comply with a time schedule for compliance; and (3) take appropriate remedial or preventive action to prevent the violation from recurring. (b) Notice to Clean. Whenever an Authorized Enforcement Official finds any oil, earth, dirt, grass, weeds, dead trees, tin cans, rubbish, refuse, waste, or any other material of any kind, in or upon the sidewalk abutting or adjoining any parcel of land or upon any parcel of land or grounds which may result in an increase in pollutants entering the City storm sewer system or a non-stormwater discharge to the City storm sewer system, he or she shall give notice to remove such oil, earth, dirt, grass, weeds, dead trees, tin cans, rubbish, refuse, waste, or other material, in any manner that he or she may reasonably provide.

\section{1-5.40 Best Management Practices During Construction}

Any construction contractor performing work in the City shall adhere to the City of Hayward's Site Design Standards and Guidance as it relates to construction Best Management Practices (BMPs) SEC. 11-5.41 Compliance with Best management Practices

Where best management practices guidelines or requirements have been adopted by any federal, State of California, regional, and/or City agency, for any activity, operation, or facility which may cause or contribute to stormwater pollution or contamination, illicit discharges, and/or discharge of nonstormwater to the stormwater system, every person undertaking such activity or operation, or owning 
or operating such facility, shall comply with such guidelines or requirements.

SEC. 11-5.43 Authority to Enforce Construction Stormwater Permits

The City of Hayward shall have the authority to enforce the permit requirements of any individual, group, or general stormwater discharge permit issued to any construction activity by the

Environmental Protection Agency, the State of California Water Resources Control Board, or the San

Francisco Bay Regional Water Quality Control Board to the extent that such authority is delegated to

the City by the issuing agency of government.

Source: Hayward, 2017

Table 13: City of Hayward Construction Violations for 2016

\begin{tabular}{|l|l|l|}
\hline City of Hayward & Number of Violation & Percentage of Violation \\
\hline BMP Category & & \\
\hline Erosion Control & 0 & $0 \%$ \\
\hline Run-On \& Run Off Control & 1 & $33 \%$ \\
\hline Sediment Control & 2 & $67 \%$ \\
\hline Active Treatment Systems & 0 & $0 \%$ \\
\hline Good Site Management & 0 & $0 \%$ \\
\hline Non Stormwater Management & 0 & $0 \%$ \\
\hline Total & 3 & $100 \%$ \\
\hline
\end{tabular}

Source, Hayward, 2016

Table 14: City of Hayward Minimum Qualifications

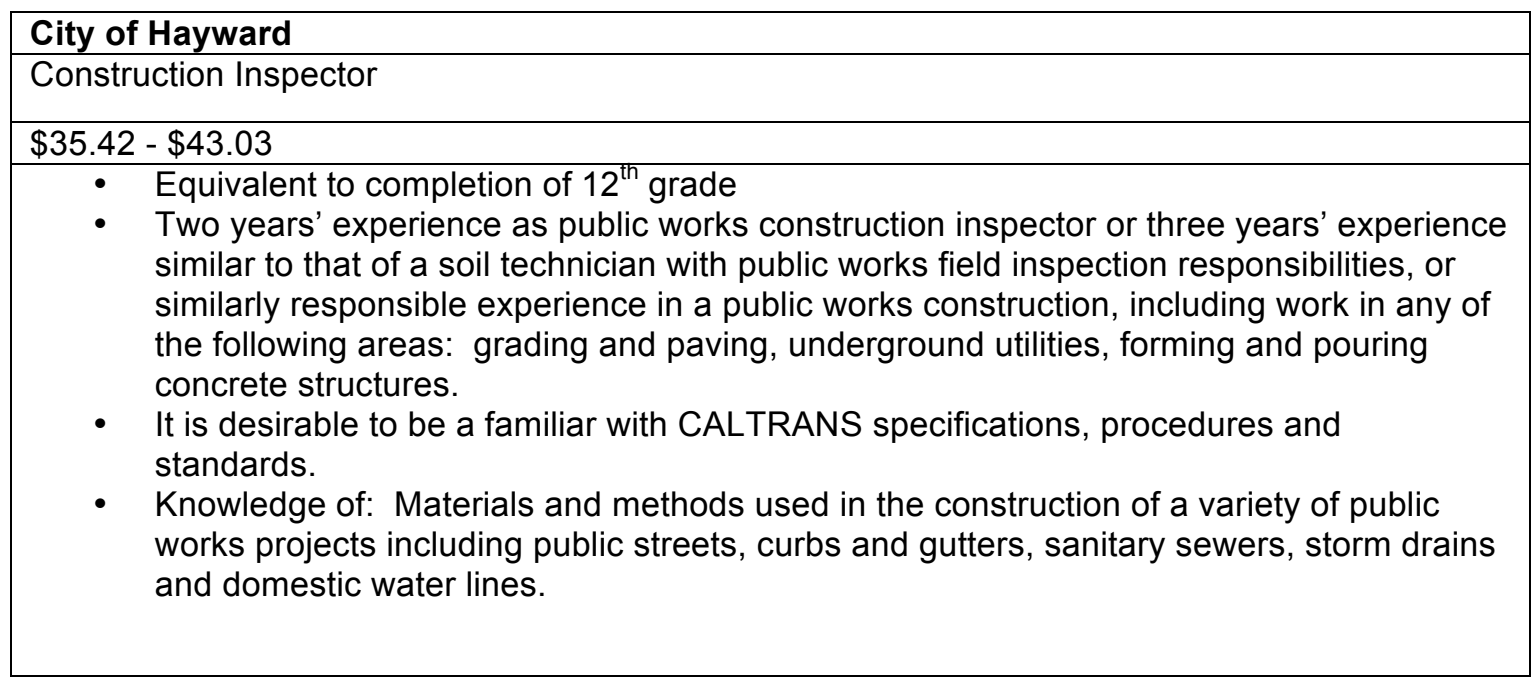

Source: Hayward, 2015 
Table 15: City of Hayward Questionnaire Results

\begin{tabular}{|c|c|}
\hline Questionnaire & City of Hayward \\
\hline $\begin{array}{l}\text { *Please answer questions best to your ability } \\
\text { and interpretation }\end{array}$ & \\
\hline $\begin{array}{l}\text { 1. Which departments are involved in the } \\
\text { issuing, review, and inspection of a grading } \\
\text { permit? }\end{array}$ & Public Works \\
\hline $\begin{array}{l}\text { 2. How many full-time employees (FTEs) are } \\
\text { assigned to the Stormwater Construction } \\
\text { Inspection Program (inspectors enforcing } \\
\text { C.6)? }\end{array}$ & Seven \\
\hline $\begin{array}{l}\text { 3. How many FTEs review erosion control } \\
\text { appropriateness and adequacy of proposed } \\
\text { Best Management Practices (BMPs) for each } \\
\text { site before issuing grading permits? }\end{array}$ & $\begin{array}{l}\text { One } \\
\text { Public Works }\end{array}$ \\
\hline $\begin{array}{l}\text { 4. Employees who review erosion control } \\
\text { plans work for which department? }\end{array}$ & Public Works \\
\hline $\begin{array}{l}\text { 5. Do the employees who review erosion } \\
\text { control plans also conduct inspections? }\end{array}$ & No \\
\hline $\begin{array}{l}\text { 6. Are site one acre or more verified to have a } \\
\text { Notice of Intent (NOI) for permit coverage } \\
\text { under the Construction General Permit } \\
\text { (CGP)? } \\
\text { If so, by whom? }\end{array}$ & $\begin{array}{l}\text { Yes. } \\
\text { The engineer reviewing the SWPPP submittal. } \\
\text { I also check prior to pre-construction meetings. }\end{array}$ \\
\hline $\begin{array}{l}\text { 7. Are Storm Water Pollution Prevention Plans } \\
\text { (SWPPP) reviewed? } \\
\text { If so, by whom? }\end{array}$ & $\begin{array}{l}\text { Yes. } \\
\text { Associate civil Engineer }\end{array}$ \\
\hline $\begin{array}{l}\text { 8. Is outreach to developers tracked? } \\
\text { If so, how much outreach was done to } \\
\text { developers in past fiscal year? }\end{array}$ & $\begin{array}{l}\text { Yes. } \\
\text { Twice for each developer. }\end{array}$ \\
\hline $\begin{array}{l}\text { 9. Is training provided to Construction } \\
\text { Inspection Program employees? } \\
\text { If so how often? }\end{array}$ & $\begin{array}{l}\text { Yes. } \\
\text { Sent to workshops annually. Storm water } \\
\text { protection discussed in house monthly }\end{array}$ \\
\hline $\begin{array}{l}\text { What challenges does your program have } \\
\text { implementing MRP requirements? }\end{array}$ & Time / employee workload \\
\hline
\end{tabular}




\section{City of Sunnyvale}

\section{Table 16: City of Sunnyvale Legal Authority}

\section{City of Sunnyvale \\ 12.60.70 Discharge prohibitions}

(a) General Prohibition. Any discharge to the storm drain system not composed entirely of stormwater is prohibited, except as set forth in this chapter. (b) It is unlawful to throw, deposit, leave, abandon, maintain or keep materials or wastes on public or private lands in a manner and place where they may result in an illicit discharge. (c) Separately Permitted Discharges. Discharges regulated under a valid facility-specific NPDES permit or facility-specific Regional Water Quality Control Board waste discharge requirements permit not including a state general permit, shall be regulated exclusively by the Regional Water Quality Control Board and are exempt from discharge prohibitions established by this chapter, provided compliance with all relevant permit conditions is maintained to the satisfaction of the Board. Stormwater discharges at a facility with a facility specific permit which only addresses process discharges or non-stormwater discharges are not exempted. (d) State General Permit Discharges. Stormwater discharges regulated under the state general industrial storm water permit or state general construction stormwater permit are exempt from discharge prohibitions established by this chapter, provided compliance with all relevant general permit conditions is maintained to the satisfaction of the Regional Water Quality Control Board. (e) Categorically Allowed Discharges. The following categories of non-stormwater discharges are exempt from discharge prohibitions established by this chapter: (1) Flows from riparian habitats or wetlands; (2) Diverted stream flows; (3) Flows from natural springs; (4) Rising ground waters; (5) Uncontaminated groundwater infiltration; (6) Pumped groundwater from drinking water aquifers; and (7) NPDES permitted discharges (individual or general permits). (f)Conditionally Exempted Discharges. The following categories of non-stormwater discharges are conditionally exempt from discharge prohibitions established by this chapter. Dischargers must install, implement and maintain any specifically applicable minimum best management practices, as set out in the NPDES Stormwater Permit (Provision C.15.b, Conditionally Exempted Non-Stormwater Discharges) to prevent or eliminate adverse impacts of such discharges: (1) Uncontaminated pumped groundwater;(2) Pumped groundwater from non-drinking water aquifers; (3) Foundation drains; (4)Water from crawl space pumps; (5)Footing drains; (6)Air condition condensate; (7) Irrigation water; (8)Landscape irrigation (9)Lawn or garden watering;(10) Planned and unplanned discharges from potable water sources; (11)Water line and hydrant flushing;(12) Individual residential car washing; (13)Swimming pool, hot tub, spa and fountain water; and (14) Emergency discharges that are the result of firefighting, unauthorized hydrant openings, natural or man-made disasters (e.g., earthquakes, floods, wildfires, accidents, terrorist actions). (g) On-Site Wastewater Systems. Discharges to the subsurface from permitted properly functioning on-site wastewater systems are not prohibited by this chapter. (h) Exemptions Not Absolute. Any discharge category described above that is a significant source of pollutant to waters of the United States shall be prohibited from entering the storm drain system, or shall be subjected to a requirement to implement additional best management practices to reduce pollutants in the discharge to the maximum extent practicable. Such prohibitions shall be effective on a schedule specified by an authorized enforcement official in a written notice to the discharger. The schedule may take into account the nature and severity of any effects caused by the discharge; and the time required to design, engineer, fund, procure, construct and make appropriate best management practices operational. (i)Non-Stormwater Discharge. The prohibition shall not apply to any non-stormwater discharge permitted under an NPDES permit, waiver, or waste discharge order issued to the discharger and administered by the state of California under the authority of the Federal Environmental Protection Agency, provided that the discharger is in full compliance with all requirements of the permit, waiver, or order and other applicable laws and regulations. The authorized enforcement official may exempt in writing other non-stormwater discharges which are not a source of pollutants to the storm drain system upon approval by the executive officer of the San Francisco Bay Regional Water Quality Control Board. (Ord. 2944-10 § 1; Ord. 2790-05 § 1; Ord. 2732-03 § 1).

\subsubsection{Compliance with NPDES stormwater permit}

Any person subject to an industrial or construction activity general NPDES stormwater discharge permit shall comply with all provisions of such permit. Proof of compliance may be required in a form 
acceptable to the authorized enforcement official prior to or as a condition of the approval of a subdivision map, site plan, building permit, development or improvement plan; upon inspection of the facility and/or during any enforcement action. (Ord. 2944-10 § 1; Ord. 2732-03 § 1).

\subsubsection{Stormwater pollution reduction}

All applicants for permits pertaining to the planning, design, and construction of all projects subject to this chapter shall design and implement stormwater best management practices so as to reduce stormwater pollution to the maximum extent practicable. Such projects shall utilize standards and guidelines set forth in the BMP Guidance Manual, as revised, and shall incorporate the numeric sizing criteria for best management practices set forth in this chapter. (Ord. 2944-10 § 1; Ord. 2790-05 § 1).

\subsection{Best management practices and CASQA Stormwater Best Management Practice} Handbook incorporated

The BMP Guidance Manual and CASQA Stormwater Best Management Practice Handbook are incorporated by reference into this chapter. The authorized enforcement official may from time to time revise or add to such manual to comply with NPDES requirements and stay current with technology and best management practices. (Ord. 2944-10 § 1; Ord. 2790-05 § 1; Ord. 2732-03 § 1).

12.60.230 Minimum best management practices and source control measures for all dischargers

The director may require submission of information to evaluate the implementation and/or require the implementation of best management practices (BMPs), including, but not limited to, the following: (a) Minimum Best Management Practices. All dischargers must implement and maintain at least the following minimum best management practices: Appropriate BMPs will be implemented to prevent pollutant sources from entering the city's storm drain collection system that are associated with outdoor process and manufacturing areas, outdoor material storage areas, outdoor waste storage and disposal areas, outdoor vehicle and equipment storage and maintenance areas, outdoor parking and access roads, outdoor wash areas, outdoor drainage from indoor areas, rooftop equipment, contaminated and erodible surfaces, or other sources determined by the director to have a reasonable potential to contribute to pollution of stormwater runoff. (b) Inspection, Maintenance, Repair and Upgrading of Best Management Practices. Best management practices at staffed and unstaffed facilities must be inspected and maintained by the discharger according to manufacturer specifications and/or the CASQA Stormwater BMP Handbooks. These best management practices must be maintained so that they continue to function as designed. Best management practices which fail must be repaired as soon as it is safe to do so. If the failure of a best management practice indicates that the best management practices in use are inappropriate or inadequate to the circumstances, the practices must be modified or upgraded to prevent any further failure in the same or similar circumstances. (c) Construction Site Stormwater Pollution Controls. All construction sites will implement effective erosion control, run-on and runoff control, sediment control, active treatment systems (as appropriate), good site management, and non-stormwater management through all phases of construction (including, but not limited to, site grading, building and finishing of lots) until the site is fully stabilized by landscaping or the installation of permanent erosion control measures. (d) All applicable sites are encouraged to include adequate source control measures to limit pollutant generation, discharge and runoff. These source control measures are identified in Section 12.60.155. (Ord. 2944-10 § 1; Ord. 2732-03 § 1).

\subsubsection{Authority to inspect}

(a) Whenever necessary to make an inspection to enforce any provision of this chapter, or whenever the authorized enforcement official has cause to believe that there exists, or potentially exists, in or upon any applicable site any condition which constitutes a violation of this chapter, the official may enter such premises at all reasonable times to inspect the premises, to inspect and copy records related to stormwater compliance, and to collect samples and take measurements. In the event the owner or occupant refuses entry after a request to enter and inspect has been made, the city is hereby empowered to seek assistance from any court of competent jurisdiction in obtaining such entry. (b)Whenever necessary to perform operations and maintenance verification inspections of installed stormwater treatment system(s) and $\mathrm{HM}$ control(s) (if any), all regulated projects shall grant site access to all representatives of the authorized enforcement official, local mosquito and vector control agency staff, and water board staff. (Ord. 2944-10 § 1; Ord. 2732-03 § 1).

\subsubsection{Manner of notification of a violation}

(a)Warning Notice or Notice of Violation. When the director finds that a user has violated, or continues to violate, any provision of this chapter, or order issued hereunder, or any other stormwater standard or 
requirement, the director may serve upon that user a verbal or written warning notice or notice of violation. The director will require corrections to occur within a reasonably short and expedient time frame commensurate with the threat to water quality. Violations that are observed by the director shall be corrected prior to the next rain event or within ten business days after the violation is first noted. If more than ten business days are required for a correction, a rationale must be provided. A rapid, temporary repair shall be required and a longer time for implementation of more permanent solutions may be allowed if significant capital expenditures or construction is required to resolve the discharge problem. (b) Explanation of Violation and Plan for Correction/Prevention. The director may require the submission of an explanation of the violation and a plan for the satisfactory correction and prevention thereof, within the time specified in the notice, to include specific required actions. Submission of such a plan in no way relieves the user of liability for any violations occurring before or after receipt of the notice of violation. Nothing in this section shall limit the authority of the director to take any action, including emergency actions or any other enforcement action, without first issuing a notice of violation. (c) Notice to Comply. (1) When the director finds that a discharge or threatened discharge of non-stormwater is taking place, has been taking place, or threatens to take place, in violation of prohibitions or limitations prescribed in this chapter, the director may, at the director's discretion, also require the user to submit for approval, with such modifications as the director deems necessary, a detailed compliance time schedule of specific actions which the user shall take in order to prevent or correct a violation of code provisions or of any permit, and to take such action in accordance with such schedule. (2) Nothing provided in this section shall limit or prohibit the city from pursuing any other remedy, legal or equitable, otherwise available to city, or from seeking sanctions in any criminal or civil action related to such discharge or potential discharge. (d) Issuance of Cease and Desist Orders. When the authorized enforcement official finds that a discharge of stormwater has taken place or is likely to take place in violation of this chapter, the authorized enforcement official may include in the notice, an order to cease and desist such discharge, or practice, or operation likely to cause such discharge and direct those persons not complying with such prohibitions, limits, requirements, or provisions to comply forthwith; comply in accordance with a time schedule set forth by the city; or take appropriate remedial or preventive action. (Ord. 2944-10 § 1; Ord. 2732-03 § 1)

Source: Sunnyvale, 2016

Table 17: City of Sunnyvale Construction Violations for 2016

\begin{tabular}{|l|l|l|}
\hline City of Sunnyvale & Number of Violation & Percentage of Violation \\
\hline BMP Category & & \\
\hline Erosion Control & 0 & $0 \%$ \\
\hline Run-On \& Run Off Control & 0 & $0 \%$ \\
\hline Sediment Control & 56 & $85 \%$ \\
\hline Active Treatment Systems & 0 & $0 \%$ \\
\hline Good Site Management & 8 & $12 \%$ \\
\hline Non Stormwater Management & 2 & $3 \%$ \\
\hline Total & 66 & $100 \%$ \\
\hline
\end{tabular}

Source: Sunnyvale, 2016 
Table 18: City of Sunnyvale Minimum Qualifications

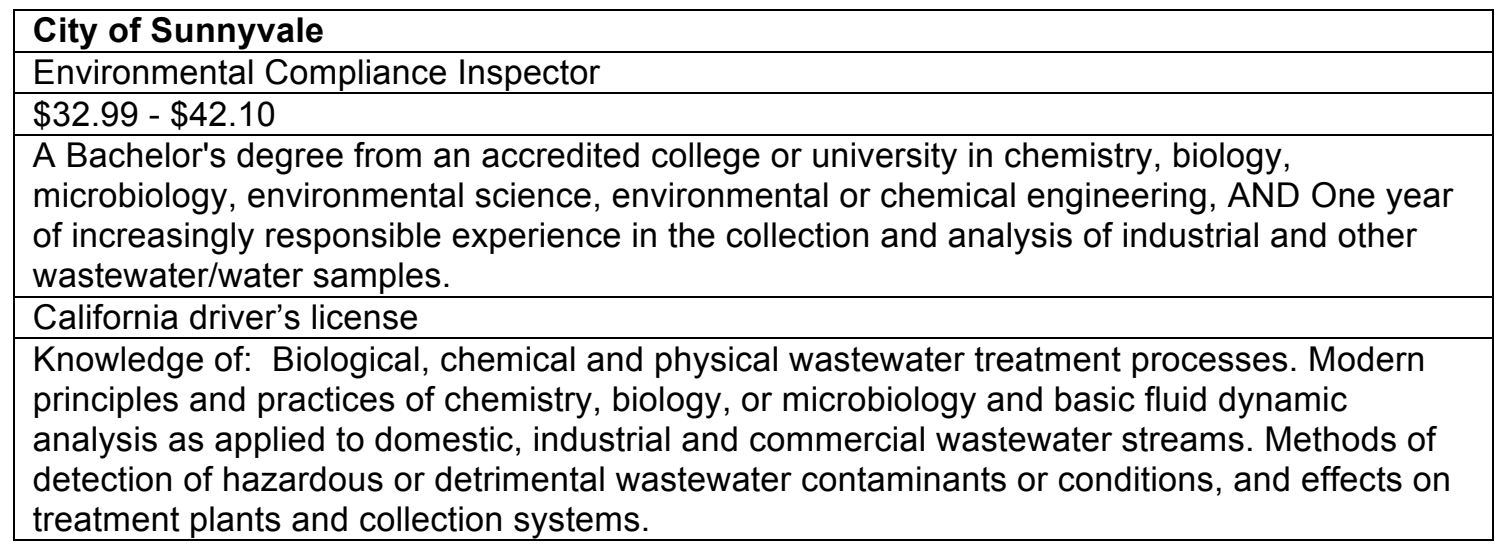

Source: Sunnyvale, 2014

The City of Sunnyvale did not submit answers to the questionnaire.

\section{City of Concord}

\section{Table 19: City of Concord Legal Authority}

\begin{tabular}{|l|}
\hline City of Concord \\
\hline $\mathbf{1 6 . 0 5 . 0 6 0}$ Prohibited Discharges \\
\hline (a) The release of non-stormwater discharges to the City stormwater system is prohibited. \\
(b) The discharge of stormwater from premises or an activity that causes or contributes to a violation of \\
receiving water limitations in the City's NPDES permit is prohibited. \\
(c) The following discharges are exempt from the prohibition set forth in subsection (a) above: \\
(1) Any discharge in compliance with a NPDES permit issued to the discharger. \\
(2) Flows from riparian habitats and wetlands, diverted stream flows, springs, rising groundwater and \\
uncontaminated groundwater infiltration. \\
(d) The following discharges are exempt from the prohibitions set forth subsection (a) above if the \\
Regional Water Quality Control Board approves the exempted category under section C. 11. of the \\
City's NPDES permit: uncontaminated pumped groundwater, foundation drains, water from crawl space \\
pumps, footing drains, air conditioning condensate, irrigation water, landscape irrigation, lawn or \\
garden watering, planned and unplanned discharges from potable water sources, water line and \\
hydrant flushing, individual residential car washing, discharges or flows from emergency fire fighting \\
activities, and dechlorinated swimming pool discharges. \\
(Code $1965, \S 5905 ;$ Code 2002, $\$ 86-36$. Ord. No. 04-4) \\
\hline $\mathbf{1 6 . 0 5 . 0 7 0 ~ D i s c h a r g e ~ i n ~ V i o l a t i o n ~ o f ~ N P D E S ~ P e r m i t ~}$ \\
\hline Any discharge that would result in or contribute to a violation of the City's NPDES permit either \\
separately considered or when combined with other discharges, is prohibited. Liability for any such \\
discharge shall be the responsibility of the person causing or responsible for the discharge, and such \\
person shall defend, indemnify and hold harmless the City in any administrative or judicial enforcement \\
action relating to such discharge. \\
(Code $1965, \S 5906 ;$ Code 2002, $\S 86-37$ ) \\
\hline $\mathbf{1 6 . 0 5 . 0 9 0 ~ B e s t ~ M a n a g e m e n t ~ P r a c t i c e s ~ a n d ~ S t a n d a r d s ~}$ \\
\hline (a) Generally. Any person owning or operating premises that may contribute pollutants to the City's \\
stormwater system shall undertake all practicable best management practices to reduce the potential \\
\hline
\end{tabular}


for pollutants entering the system. Examples of such premises include, but are not limited to, parking lots, gasoline stations, industrial facilities, and other commercial enterprises.

(b) Litter. No person shall throw, deposit, leave, keep or permit to be thrown, deposited, placed, left or maintained, any refuse, rubbish, garbage or other discarded or abandoned objects, articles or other litter in or upon any street, alley, sidewalk, gutter, business place, creek, stormwater system, fountain, pool, lake, stream, river or any other body of water, or upon any public or private parcel of land so that the same might become a pollutant, except in containers or in lawfully established waste disposal facilities.

(c) Sidewalks. The owner or occupant of any real property in front of which there is a paved sidewalk shall maintain said sidewalk free of dirt or litter to the maximum extent practicable. Sweepings from the sidewalk shall not be swept or otherwise made or allowed to go into the gutter or roadway, but shall be disposed of in receptacles maintained as required for the disposal of solid waste.

(d) Parking Lots, Paved Areas and Related Stormwater Systems. Persons owning, operating or maintaining a paved parking lot, the paved areas of a gasoline station, a paved private street or road, and related stormwater systems shall clean those premises as frequently and thoroughly as practicable in a manner that does not result in the discharge of pollutants to the City's stormwater system.

(e) Construction Activities. All construction shall conform to the requirements of the CASQA

Stormwater Best Management Practices Handbooks for Construction Activities and New Development and Redevelopment, the ABAG Manual of Standards for Erosion \& Sediment Control Measures, the City's grading and erosion control ordinance and other generally accepted engineering practices for erosion control as required by the Director when undertaking construction activities. The Director may establish controls on the rate of stormwater runoff from new developments and redevelopment as may be appropriate to minimize the discharge and transport of pollutants.

(f) Notification of Intent and Compliance with General Permits. Each discharger associated with construction activity or other discharger described in any general stormwater permit addressing discharges, as may be adopted by the United States Environmental Protection Agency, the State Water Resources Control Board, or the California Regional Water Quality Control Board, San Francisco Bay Region, shall provide the Director with the notice of intent, comply with and undertake all other activities required by any general stormwater permit applicable to such dischargers. Each discharger identified in an individual NPDES permit relating to stormwater discharges shall comply with and undertake all activities required by the permit.

(g) Development Runoff Requirements. For each new development and redevelopment project subject to the development runoff requirements, every applicant shall submit a stormwater control plan and implement conditions of approval that reduce stormwater pollutant discharges through the construction, operation and maintenance of treatment measures and other appropriate source control and site design measures. Similarly, increases in runoff volume and flows shall be managed in accordance with the development runoff requirements.

(h) Compliance with Best Management Practices. Where best management practices guidelines or requirements have been adopted by any federal, state, regional, city or county agency, for any activity, or operation of premises which may cause or contribute to non-stormwater discharges, every person undertaking such activity, operation or owning and operating such premises shall comply with such guidelines or requirements.

(i) Stormwater Pollution Prevention Plan. The Director may require any business or utility in the City that is engaged in activities that may result in non-stormwater discharges or runoff pollutants to develop and implement a stormwater pollution prevention plan, which must include an employee training program. Business activities which may require a stormwater pollution prevention plan include maintenance, storage, manufacturing, assembly, equipment operations, vehicle loading, fueling, vehicle maintenance, food handling or processing, or cleanup procedures which is carried out partially or wholly out of doors.

(j) Coordination with Hazardous Material Release Response and Inventory Plans. Any business subject to the Hazardous Material Release Response and Inventory Plan, Division 20, chapter 6.95 of the California Health and Safety Code (commencing with section 2550), shall include, in that Plan, provision for compliance with this article, including the prohibitions of non-stormwater discharges and the requirement to reduce release of pollutants to the maximum extent practicable.

(Code 1965, § 5908; Code 2002, § 86-39. Ord. No. 04-4)

16.05.110 Authority to Inspect 
(a) Generally. Routine or scheduled inspections shall be based upon as reasonable a selection process as may be deemed necessary to carry out the intent of this article, including, but not limited to, random sampling or sampling in areas with evidence of stormwater contamination, evidence of the discharge of non-stormwater to the stormwater system, or similar activities. Inspections may also be conducted in conjunction with routine or scheduled inspections conducted by other public agencies or special district, including but not limited to the Central Contra Costa Sanitary District, the Contra Costa County Fire Protection District, County Environmental Health Department, the Contra Costa Mosquito and Vector Control District, or the Regional Water Quality Control Board.

(b) Authority to Sample and Establish Sampling Devices. With the consent of the owner or occupant, or pursuant to a search or inspection warrant, any Officer may establish on any property such devices as are necessary to conduct sampling or metering operations. During all authorized inspections, the Officer may take any sample deemed necessary to aid in the pursuit of the inquiry or in the recordation of the activities on site.

(c) Notification of Spills. All persons in charge of the premises or responsible for emergency response for the premises have a responsibility to train premises' personnel and maintain notification procedures to ensure that immediate notification is provided to the City of any suspected, confirmed or unconfirmed release of pollutants creating a risk of non-stormwater discharge into the City stormwater system. As soon as any person in charge of the premises or responsible for emergency response for the premises has knowledge of any suspected, confirmed or unconfirmed release of non-stormwater discharge entering the City stormwater system, such person shall take all necessary steps to ensure the detection and containment and clean up of such release and shall notify the City of the occurrence by telephoning the Director. This notification requirement is in addition to and not in lieu of other required notifications.

(d) Requirement to Test or Monitor. Any Officer may require that any person engaged in any activity or owning or operating any premises that may cause or contribute to non-stormwater discharges, undertake such monitoring activities or analysis and furnish such reports as the Officer may specify. The burden, including costs of these activities, analysis and reports shall bear a reasonable relationship to the need for the monitoring, analysis and reports and the benefits to be obtained. The recipient of such request shall undertake and provide the monitoring, analysis and reports required. (Code 1965, § 5910; Code 2002, § 86-41. Ord. No. 04-4)

Source: Concord, 2017

Table 20: City of Concord Construction Violations 2016

\begin{tabular}{|l|l|l|}
\hline City of Concord & Number of Violation & Percentage of Violation \\
\hline BMP Category & & \\
\hline Erosion Control & 0 & $0 \%$ \\
\hline Run-On \& Run Off Control & 0 & $0 \%$ \\
\hline Sediment Control & 0 & $0 \%$ \\
\hline Active Treatment Systems & 0 & $0 \%$ \\
\hline Good Site Management & 0 & $0 \%$ \\
\hline Non Stormwater Management & 0 & $0 \%$ \\
\hline Total & 0 & $0 \%$ \\
\hline
\end{tabular}

Source: Concord, 2016 
Table 21: City of Concord Minimum Qualifications

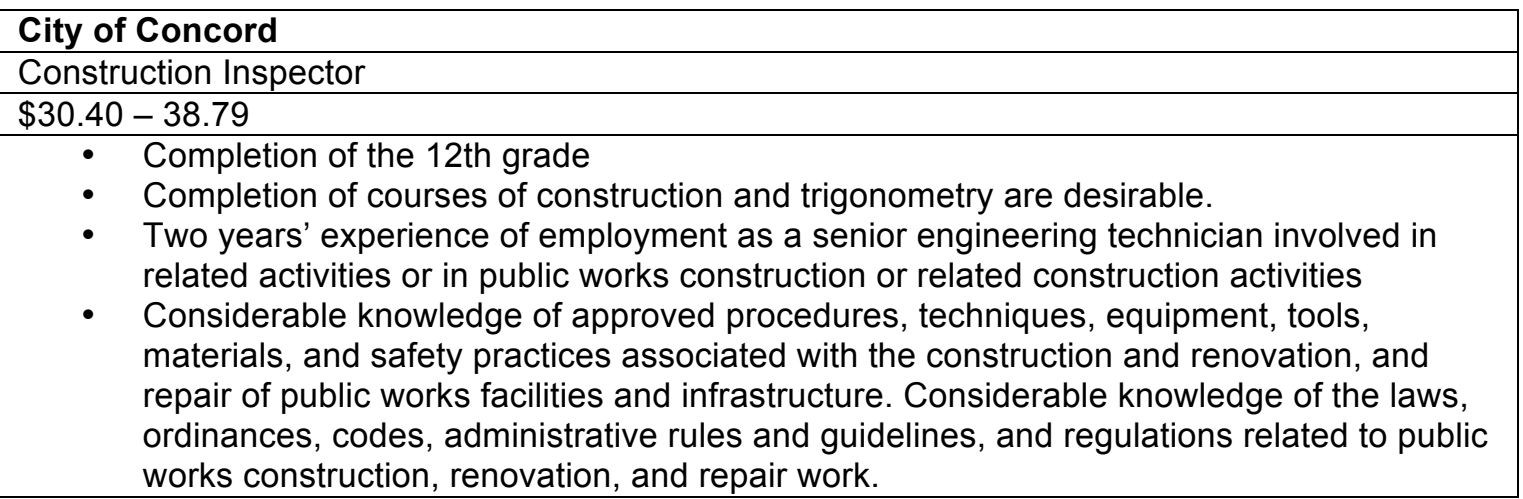

Source: Concord, 2012

Table 22: City of Concord Questionnaire Results

\begin{tabular}{|l|l|}
\hline Questionnaire & City of Concord \\
\hline $\begin{array}{l}\text { *Please answer questions best to your ability } \\
\text { and interpretation }\end{array}$ & \\
\hline $\begin{array}{l}\text { 1. Which departments are involved in the } \\
\text { issuing, review, and inspection of a grading } \\
\text { permit? }\end{array}$ & $\begin{array}{l}\text { Community and Economic Development } \\
\text { Department } \\
\text {-Engineering and Planning Divisions }\end{array}$ \\
\hline $\begin{array}{l}\text { 2. How many full-time employees (FTEs) are } \\
\text { assigned to the Stormwater Construction } \\
\text { Inspection Program (inspectors enforcing } \\
\text { C.6)? }\end{array}$ & $\begin{array}{l}\text { Four (4) construction inspectors with oversight } \\
\text { by two (2) engineers- amongst many duties- no } \\
\text { FTE's exclusively assigned to Storm Water } \\
\text { program only }\end{array}$ \\
\hline $\begin{array}{l}\text { 3. How many FTEs review erosion control } \\
\text { appropriateness and adequacy of proposed } \\
\text { Best Management Practices (BMPs) for each } \\
\text { site before issuing grading permits? }\end{array}$ & $\begin{array}{l}\text { Two (2) -one (1) engineer and one (1) } \\
\text { construction inspector (per plan/permit) }\end{array}$ \\
\hline $\begin{array}{l}\text { 4. Employees who review erosion control } \\
\text { plans work for which department? }\end{array}$ & $\begin{array}{l}\text { Community and Economic Development Dept.- } \\
\text { Engineering Division only }\end{array}$ \\
\hline $\begin{array}{l}\text { 5. Do the employees who review erosion } \\
\text { control plans also conduct inspections? }\end{array}$ & $\begin{array}{l}\text { Yes, the Construction Inspectors throughout } \\
\text { and occasionally are an engineer }\end{array}$ \\
\hline $\begin{array}{l}\text { 6. Are site one acre or more verified to have a } \\
\text { Notice of Intent (NOI) for permit coverage } \\
\text { under the Construction General Permit } \\
\text { (CGP)? }\end{array}$ & $\begin{array}{l}\text { Yes } \\
\text { If so, by whom? }\end{array}$ \\
$\begin{array}{l}\text { 7. Are Storm Water Pollution Prevention Plans } \\
\text { (SWPPP) reviewed? }\end{array}$ & $\begin{array}{l}\text { Not typically both the engineer and construction } \\
\text { inspector }\end{array}$ \\
\hline
\end{tabular}




\begin{tabular}{|l|l|}
\hline & \\
\hline $\begin{array}{l}\text { 8. Is outreach to developers tracked? } \\
\text { If so, how much outreach was done to } \\
\text { developers in past fiscal year? }\end{array}$ & Question is unclear \\
\hline $\begin{array}{l}\text { 9. Is training provided to Construction } \\
\text { Inspection Program employees? }\end{array}$ & $\begin{array}{l}\text { Yes, Once every two (2) years through the } \\
\text { Clean Water Program, and by City staff or } \\
\text { Storm Water consultants during the interim } \\
\text { year }\end{array}$ \\
If so how often? & $\begin{array}{l}\text { The same challenges as with any municipality. } \\
\text { Added requirements every year, vested } \\
\text { projects being out of compliance with current } \\
\text { regulations, tracking and reporting for projects } \\
\text { which stop and start without notification, lack of } \\
\text { funding source. }\end{array}$ \\
\hline
\end{tabular}

\section{City of Santa Clara}

\section{Table 23: City of Santa Clara Legal Authority}

\section{City of Santa Clara \\ 13.20.030 Discharge into the Storm Drain Prohibited}

a) It shall be unlawful to discharge, or cause, allow, or permit to be discharged into any storm drain, storm sewer, or natural outlet or channel any waste, including, but not limited to, sewage, industrial wastes, petroleum products, coal tar, or any refuse substance arising from the manufacture of gas from coal or petroleum, chemicals, detergents, solvents, paints, contaminated water, or chlorinated swimming pool water, pesticides, herbicides, fertilizers, or other process wastewater. (b) No person shall discharge any substance directly into a manhole or other opening in a City storm drain or storm sewer other than through a City-approved storm drain connection. (c) Upon permit application and approval by the Director of Streets and Automotive Services, unpolluted water may be discharged into the City's storm drain system or into a natural outlet. No discharge other than rainfall runoff shall be allowed, except for such discharge as is expressly permitted by the City's permit and the National Pollution Discharge Elimination System (NPDES) and will not cause any impairment in the beneficial uses or quality of water of the State as defined in the California Water Code, or any special requirements of the Regional Water Quality Control Board, San Francisco Bay Region, or injure or interfere with the City's storm drain system or the operation of the State's watercourses. (d) The City may, from time to time, by resolution of the City council, adopt supplementary rules and regulations on discharge into any storm drain or natural outlet or channel that shall have the same force and effect as if set forth herein and for which the remedies herein for violation shall be applicable. (Ord. 1655 § 1, 426-94; Ord. $1771 \S 3,8-20-02$. Formerly § 24-3)

\subsubsection{Monitoring of Discharge into the Storm Drain System.}

(a) When deemed necessary by the City Manager or his/her duly authorized agents and representatives, he/she shall require any person to monitor their storm drain discharges to ensure compliance with allowable discharges. (b) Where BMP guidelines or requirements have been adopted by any Federal, State, regional, County, or local agency, for any activity, operation, or facility that may cause or contribute to stormwater pollution or contamination, illicit discharges, discharges of nonstormwater to the stormwater system, every person undertaking such activity or operation, or owning or operating such facility, shall comply with such guidelines or requirements as may be identified by the City Manager or his/her duly authorized agents and representatives. (Ord. $1655 \S 1$, 4-26-94. Formerly $\S 24-5)$

13.20.080 Discharge Pursuant to City and/or NPDES Permit

(a) Subject to review and approval under SCCC 13.20.020, the provisions of this chapter shall not 
prohibit any discharge in compliance with a valid NPDES permit issued to the discharger. (b) Any discharge that would result in or contribute to a violation of the City-issued permit and the City's NPDES permit (this permit is available for viewing at the City of Santa Clara, Office of the City Clerk, 1500 Warburton Avenue, Santa Clara, California) and any amendment, revision, or reissuance thereof, either separately considered or when combined with other discharges, is prohibited. Liability for any such discharge shall be the responsibility of the person causing or responsible for the discharge, and such person shall protect, defend, indemnify and hold harmless the City in any administrative or judicial enforcement action relating to such action. (Ord. $1655 \S 1,4-26-94$. Formerly § 24-8)

13.20.090 Criminal or civil penalty for violation, payment of funds to account

a) Enforcement. See SCCC 13.25.010. (b) Citation Authority. The following designated employee positions may enforce the provisions of this chapter by issuance of citations. Persons employed in such positions are authorized to exercise the authority provided in Penal Code Section 836.5 and are authorized to issue citations for violations of this chapter. The designated employee positions are the City Manager, or his/her duly authorized agents and representatives. (Ord. 1655 § 1, 4-26-94; Ord. $1771 \S 4,8-20-02$. Formerly § 24-9).

\subsubsection{Administrative Penalties}

Whenever the City Manager (or his/her duly authorized agents and representatives) finds that any person has violated any notice of violation requiring compliance with any provision of this chapter, or has violated any provision of this chapter, he/she may assess an administrative penalty in a sum not to exceed one thousand dollars $(\$ 1,000.00)$ per day, excluding inspection costs, or cleanup or abatement costs. The remedy provided in this section shall be pursuant to administrative procedures and is cumulative and not exclusive, and shall be in addition to all other remedies available to the City under State and Federal law and local ordinances. Funds collected pursuant to this section shall be paid to City's storm drain environmental compliance fee account. (Ord. $1655 \S 1,4-26-94$. Formerly $\S 24-11$ )

Source: Santa Clara, 2017

Table 24: City of Santa Clara Construction Violations 2016

\begin{tabular}{|l|l|l|}
\hline City of Santa Clara & Number of Violation & Percentage of Violation \\
\hline BMP Category & & \\
\hline Erosion Control & 12 & $6 \%$ \\
\hline Run-On \& Run Off Control & 35 & $20 \%$ \\
\hline Sediment Control & 69 & $39 \%$ \\
\hline Active Treatment Systems & 0 & $0 \%$ \\
\hline Good Site Management & 54 & $30 \%$ \\
\hline Non Stormwater Management & 7 & $4 \%$ \\
\hline Total & 177 & $100 \%$ \\
\hline
\end{tabular}

Source: Santa Clara, 2016 
Table 25: City of Santa Clara Minimum Qualifications

\begin{tabular}{|c|c|}
\hline City of Santa Clara \\
\hline Public Works Inspector \\
\hline$\$ 42.88$ - $\$ 54.86$ \\
\hline$\bullet$ & Education equivalent to completion of the twelfth grade \\
\hline & $\begin{array}{l}\text { Two years of responsible engineering field inspection work on public works projects. } \\
\text { (60 college units may be substituted for up to one year of experience). }\end{array}$ \\
\hline - & Possession of a valid CA drivers license \\
\hline & Knowledge of: The methods, materials and equipment used in public works \\
& $\begin{array}{l}\text { construction; The CAL OSHA Construction Safety Orders and traffic safety } \\
\text { procedures in construction areas; Common materials testing techniques; The } \\
\text { principles of algebra, geometry and trigonometry and their application to engineering } \\
\text { construction; and Environmental and safety practices, procedures and standards e.g. } \\
\text { confined space and trench safety. }\end{array}$ \\
\hline
\end{tabular}

Source: Santa Clara, 2008

Table 26: City of Santa Clara Questionnaire Results

\begin{tabular}{|c|c|}
\hline Questionnaire & City of Santa Clara \\
\hline $\begin{array}{l}\text { *Please answer questions best to your ability } \\
\text { and interpretation }\end{array}$ & \\
\hline $\begin{array}{l}\text { 1. Which departments are involved in the } \\
\text { issuing, review, and inspection of a grading } \\
\text { permit? }\end{array}$ & $\begin{array}{l}\text { Planning does the zoning and environmental } \\
\text { clearance concurrently with review and } \\
\text { clearances by Building, Public Works - } \\
\text { Engineering, our Electric Utility (Silicon Valley } \\
\text { Power) and Water Utility departments, before } \\
\text { Building will issue the permit. }\end{array}$ \\
\hline $\begin{array}{l}\text { 2. How many full-time employees (FTEs) are } \\
\text { assigned to the Stormwater Construction } \\
\text { Inspection Program (inspectors enforcing } \\
\text { C.6)? }\end{array}$ & $\begin{array}{l}\text { Currently the inspections are split between } 2 \\
\text { inspectors (Code Enforcement Technicians in } \\
\text { Public Works/Storm Drain Division) during the } \\
\text { rainy season, and each only devotes a portion } \\
\text { of their time to C.6. ( } 2 \times 0.25 \text { FTE }=0.5 \text { FTE) }\end{array}$ \\
\hline $\begin{array}{l}\text { 3. How many FTEs review erosion control } \\
\text { appropriateness and adequacy of proposed } \\
\text { Best Management Practices (BMPs) for each } \\
\text { site before issuing grading permits? }\end{array}$ & $\begin{array}{l}\text { The project planner and the building plans } \\
\text { examiner review the erosion control plans for } \\
\text { adequacy prior to issuing the grading permits. } \\
\text { Unfortunately l'm not sure what percentage of } \\
\text { their time is dedicated to this task. }\end{array}$ \\
\hline $\begin{array}{l}\text { 4. Employees who review erosion control } \\
\text { plans work for which department? }\end{array}$ & $\begin{array}{l}\text { I believe only Community Development } \\
\text { (Planning and Building) reviews the erosion } \\
\text { control plans at this time. }\end{array}$ \\
\hline $\begin{array}{l}\text { 5. Do the employees who review erosion } \\
\text { control plans also conduct inspections? }\end{array}$ & $\begin{array}{l}\text { No. The C. } 6 \text { construction inspections (which } \\
\text { would include evaluation of erosion controls) } \\
\text { are done by the } 2 \text { C. } 6 \text { inspectors listed in the } \\
\text { answer to question } 2 \text {. }\end{array}$ \\
\hline $\begin{array}{l}\text { 6. Are site one acre or more verified to have a } \\
\text { Notice of Intent (NOI) for permit coverage } \\
\text { under the Construction General Permit } \\
(C G P) \text { ? } \\
\text { If so, by whom? }\end{array}$ & Yes. \\
\hline
\end{tabular}




\begin{tabular}{|c|c|}
\hline $\begin{array}{l}\text { 7. Are Storm Water Pollution Prevention Plans } \\
\text { (SWPPP) reviewed? } \\
\text { If so, by whom? }\end{array}$ & $\begin{array}{l}\text { By the } 2 \text { C. } 6 \text { inspectors listed above prior to } \\
\text { and during construction site inspections. }\end{array}$ \\
\hline $\begin{array}{l}\text { 8. Is outreach to developers tracked? } \\
\text { If so, how much outreach was done to } \\
\text { developers in past fiscal year? }\end{array}$ & $\begin{array}{l}\text { Not really. We occasionally record instances } \\
\text { where developers were given outreach } \\
\text { materials (BMP handouts, etc.) but not always. } \\
\text { We also provide development applicants with a } \\
\text { Stormwater Applicant Packet, which briefly } \\
\text { defines the NPDES permit and introduces the } \\
\text { different stormwater treatment measures } \\
\text { available to facilitate stormwater treatment } \\
\text { design and provides links to materials available } \\
\text { online }\end{array}$ \\
\hline $\begin{array}{l}\text { 9. Is training provided to Construction } \\
\text { Inspection Program employees? } \\
\text { If so how often? }\end{array}$ & $\begin{array}{l}\text { Yes. } \\
\text { Construction inspectors attend annual } \\
\text { SCVURPPP training workshops, and have also } \\
\text { recently participated in training as part of the } \\
\text { QSP application process. QSP is not currently } \\
\text { required for our inspectors, but we have paid } \\
\text { for the training as ongoing professional } \\
\text { development. }\end{array}$ \\
\hline $\begin{array}{l}\text { What challenges does your program have } \\
\text { implementing MRP requirements? }\end{array}$ & $\begin{array}{l}\text { We seem to be doing ok with regard to the C. } 6 \\
\text { requirements. Our inspectors are able to } \\
\text { access the information they need to schedule } \\
\text { and conduct inspections, and to enforce the } \\
\text { requirements of both the MRP and the city } \\
\text { code. Currently one of our biggest challenges } \\
\text { is ensuring that all of our departments are on } \\
\text { the same page regarding C.3 } \\
\text { development/redevelopment requirements. We } \\
\text { are working to improve our development } \\
\text { project tracking software (currently separate } \\
\text { from our stormwater inspection tracking } \\
\text { software) so that our stormwater } \\
\text { inspections/requirements will appear similarly } \\
\text { to other hold-inducing building } \\
\text { inspections/requirements to ensure that they } \\
\text { are completed at the right times. Often there is } \\
\text { miscommunication regarding stormwater } \\
\text { control plan approvals, treatment measure } \\
\text { installation inspections, and O\&M agreements } \\
\text { with the city. }\end{array}$ \\
\hline
\end{tabular}




\section{City of Vallejo}

\section{Table 27: City of Vallejo Legal Authority}

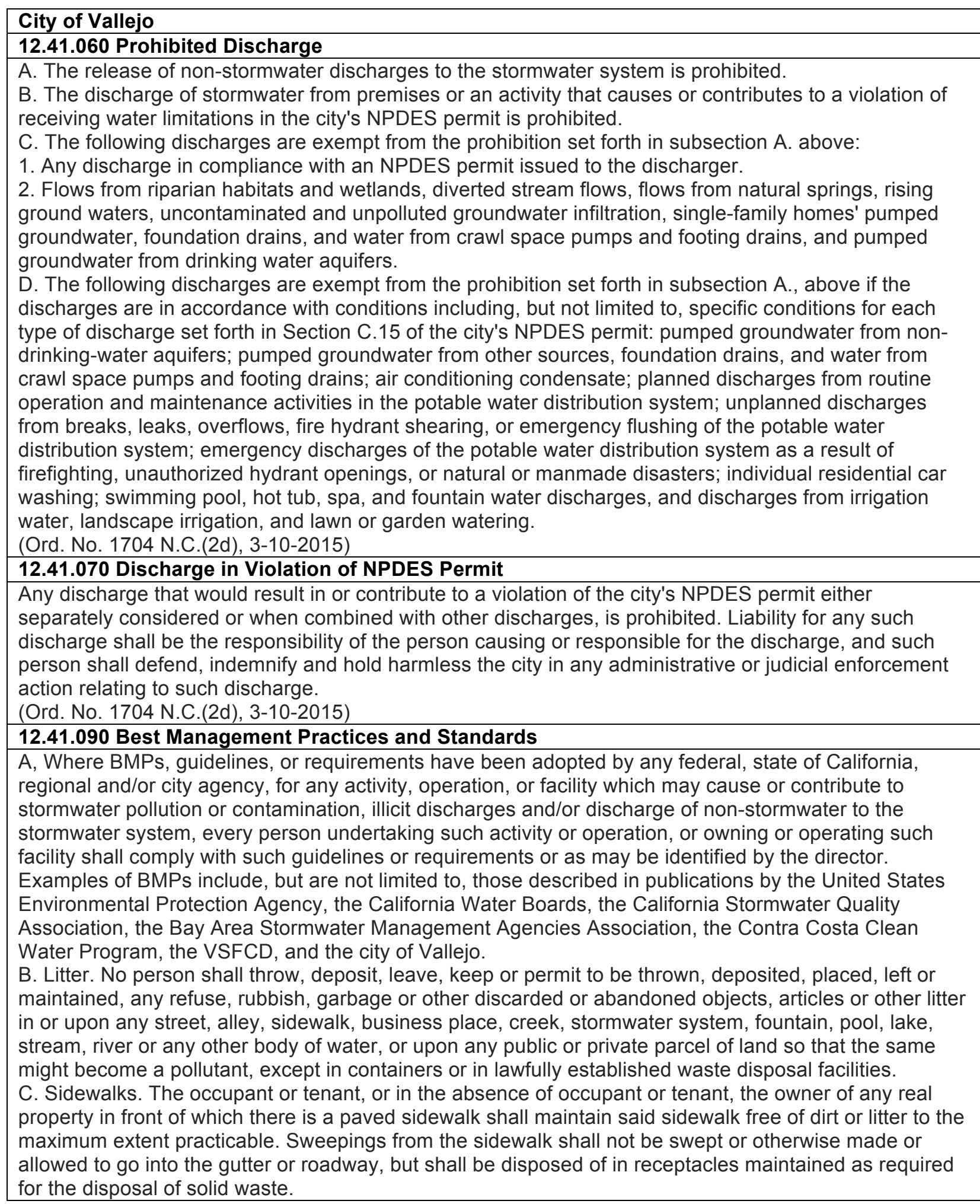


D. Maintenance of Facilities and Landscaped Areas. BMPs shall be implemented to minimize the release of pesticides, fertilizers, herbicides, and other related materials used to maintain landscaping and facilities.

E. Parking Lots, Paved Areas and Related Stormwater Systems. Persons owning, operating or maintaining a paved parking lot, the paved areas of a gasoline station, a paved private street or road, and related stormwater systems shall clean those premises as frequently and thoroughly as practicable in a manner that does not result in the discharge of pollutants to the stormwater system. The director may require installation and maintenance of devices or facilities to prevent the discharge of trash or other pollutants from private parking lots, streets, roads, and drainage facilities into the storm drain system.

F. Construction Activities. Any construction contractor performing work in the city, where discharge of stormwater to the stormwater system is possible, shall at a minimum implement BMPs to retain any debris, dirt, or other pollutant on the project site from flowing into the stormwater system. The director may establish controls on the volume and rate of stormwater runoff from new developments and redevelopments as may be appropriate to minimize the discharge and transport of pollutants. All construction sites must implement and maintain at least the following minimum BMPs:

1. Erosion control at the site;

2. Run-on and run-off controls to and from the site;

3. Control of sediments and fines on the site;

4. Active treatment systems (as necessary);

5. Good site management;

6. Non-stormwater management.

G. Notification of Intent and Compliance with General Permits. Each discharger associated with construction activity or other discharger described in any general stormwater permit addressing discharges, as may be adopted by the United States Environmental Protection Agency, the State Water Resources Control Board, or the California Regional Water Quality Control Board, San Francisco Bay Region, shall provide the director with the notice of intent, comply with and undertake all other activities required by any general stormwater permit applicable to such dischargers. Each discharger identified in an individual NPDES permit relating to stormwater discharges shall comply with and undertake all activities required by the permit.

$\mathrm{H}$. Development Runoff Requirements. For each new development project subject to the development runoff requirements, every applicant shall submit a stormwater control plan and implement conditions of approval that reduce stormwater pollutant discharges through the construction, operation and maintenance of treatment measures and other appropriate source control and site design measures. Similarly, increases in runoff volume, flows, and durations shall be managed in accordance with the development runoff requirements.

I. Stormwater Pollution Prevention Plan. The director may require any business or utility in the city that is engaged in activities that may result in non-stormwater discharges or runoff pollutants to develop and implement a stormwater pollution prevention plan, which must include an employee training program. Business activities which may require a stormwater pollution prevention plan include maintenance, storage, manufacturing, assembly, equipment operations, vehicle loading, fueling, vehicle maintenance, food handling or processing, or cleanup procedures, carried out partially or wholly outdoors.

J. Coordination with Hazardous Material Release Response and Inventory Plans. Any business subject to the Hazardous Material Release Response and Inventory Plan, California Health and Safety Code Section 25500 et seq. shall include, in that plan, provision for compliance with this chapter, including the prohibitions of non-stormwater discharges and the requirement to reduce release of pollutants to the maximum extent practicable.

(Ord. No. 1704 N.C.(2d), 3-10-2015)

\subsubsection{Inspection and Monitoring}

A. Authority to Inspect. The city shall have the right to perform routine site or area inspections. The inspections shall be based upon such reasonable selection processes as may be deemed necessary by the city to carry out the objectives of this chapter, including, but not limited to, random sampling and/or sampling in areas with evidence of stormwater contamination, illicit discharges, discharge of nonstormwater to the public storm sewer system, or similar factors. Whenever necessary to make an inspection to enforce any of the provisions of this chapter, or whenever the city has reasonable cause to believe that there exists in any building or upon any premises any condition which constitutes a violation 
of the provisions of this chapter, the city shall be permitted to enter such building or premises, without delay. Provided that (1) if such building or premises be occupied, the city shall first request entry; and (2) if such building or premises be unoccupied, the city shall first make a reasonable effort to locate the owner or other persons having charge or control of the building or premises and request entry. Any such request for entry shall state that the property owner or occupant has the right to refuse entry and that in the event such entry is refused, the city may seek assistance from any court of competent jurisdiction in obtaining such entry. Inspections may be conducted in conjunction with routine or scheduled inspections conducted by other public agencies or special districts, including but not limited to the VSFCD, Solano County Environmental Health, the Solano County Mosquito Abatement District, and the Regional Water Quality Control Board. The city council may by resolution establish a schedule of fees for inspections. B. Authority to Sample and Establish Sampling Devices. The city shall have the right to establish on any property, including within the building(s) on such property, such devices as are necessary to conduct sampling or metering operations deemed necessary to aid in the pursuit of any inquiry or in the recordation of the activities on any individual site.

C. Requirement to Test or Monitor. The city has the right to request that any person engaged in any activity and/or owning or operating any facility which may cause or contribute to stormwater pollution or contamination, illicit discharges, and/or discharge of non-stormwater to the storm drain system, undertake such monitoring activities and/or analyses and furnish such reports as the city may specify. The recipient of such request shall undertake and bear the cost of providing the monitoring, analyses and/or reports requested.

(Ord. No. 1704 N.C.(2d), 3-10-2015)

\subsubsection{Violations}

A. The violation of any provisions of this chapter, or failure to comply with any of the mandatory requirements of this article shall constitute a misdemeanor, except that notwithstanding any other provisions of this article, any violation constituting a misdemeanor under this chapter may, at the discretion of the officer or city attorney, be charged and prosecuted as an infraction.

B. Any person required to perform monitoring, analysis, reporting or corrective activity pursuant to this chapter by any officer shall be informed in writing by a notice of violation. Any person aggrieved by the decision of the officer, may file a written appeal of the notice of violation to the director within ten days following the date of the notice of violation. Upon receipt of such request, the director shall request a report and recommendation from the officer and shall set the matter for hearing at the earliest practical date. At said hearing, all evidence and testimony deemed relevant and admissible by the director shall be considered, and the director may reject, affirm, or modify the officer's decision. Formal rules of evidence shall not apply. The decisions of the director shall be final. Failure to request a hearing or appear at the hearing shall constitute a waiver and failure to exhaust administrative remedies.

C. In addition to the penalties and procedures provided herein, any condition caused or permitted to exist in violation of any of the provisions of this chapter is a threat to the public health, safety and welfare. Such condition is hereby declared and deemed to be a nuisance, which may be enforced through the administrative citation provisions of Chapter 1.15. In addition to any other remedies provided in this section, a violation of this chapter may be enforced by civil action by the city to abate, enjoin or otherwise compel the cessation of such nuisance.

(Ord. No. 1704 N.C.(2d), 3-10-2015)

\subsubsection{Acts Potentially Resulting in Violation of the Federal Clean Water Act or Porter- Cologne Act}

Any person who violates any provision of this chapter, or the provisions of any permit issued pursuant to this chapter, or who releases a non-stormwater discharge, or who violates any cease and desist order, prohibition or effluent limitation, may also be in violation of the Federal Clean Water Act or the PorterCologne Act and may be subject to the enforcement provisions of those Acts, including civil and criminal penalties. Any enforcement actions authorized pursuant to this chapter may also include notice to the violator of such potential liability pursuant to federal or state law.

(Ord. No. 1704 N.C.(2d), 3-10-2015)

Source: Vallejo, 2013 
Table 28: City of Vallejo Construction Violations 2016

\begin{tabular}{|l|l|l|}
\hline City of Vallejo & Number of Violation & Percentage of Violation \\
\hline BMP Category & & \\
\hline Erosion Control & 0 & $0 \%$ \\
\hline Run-On \& Run Off Control & 0 & $0 \%$ \\
\hline Sediment Control & 7 & $39 \%$ \\
\hline Active Treatment Systems & 0 & $0 \%$ \\
\hline Good Site Management & 11 & $61 \%$ \\
\hline Non Stormwater Management & 0 & $0 \%$ \\
\hline Total & 18 & $100 \%$ \\
\hline
\end{tabular}

Source: Vallejo, 2016

\section{Table 29: City of Vallejo Minimum Qualifications}

\begin{tabular}{|c|c|}
\hline City & f Vallejo \\
\hline Senic & Engineering Technician/Inspector \\
\hline$\$ 32.8$ & - \$39.96 \\
\hline$\bullet$ & $\begin{array}{l}\text { Three (3) years of increasingly responsible technical engineering \& experience in the } \\
\text { areas of drafting, design and construction inspection. }\end{array}$ \\
\hline & $\begin{array}{l}\text { High School diploma or GED and at least fifteen (15) semester units of college level } \\
\text { courses covering subjects such as engineering, drafting, construction inspection, } \\
\text { constriction management, water treatment and distribution systems., hydrology, } \\
\text { environmental design, or other topics related to assigned areas of responsibility. }\end{array}$ \\
\hline & $\begin{array}{l}\text { Knowledge of: Techniques and practices of land surveying. Trigonometry as applied } \\
\text { to the computation of angles, areas, distances, and traverses. Design and } \\
\text { construction theory and engineering design standards. }\end{array}$ \\
\hline
\end{tabular}

Source: Vallejo, 2007 


\section{Table 30: City of Vallejo Questionnaire Results}

\begin{tabular}{|c|c|}
\hline & City of Vallejo \\
\hline $\begin{array}{l}\text { *Please answer questions best to your ability } \\
\text { and interpretation }\end{array}$ & \\
\hline $\begin{array}{l}\text { 1. Which departments are involved in the } \\
\text { issuing, review, and inspection of a grading } \\
\text { permit? }\end{array}$ & $\begin{array}{l}\text { Public Works Department Engineering/Current } \\
\text { Development section }\end{array}$ \\
\hline $\begin{array}{l}\text { 2. How many full-time employees (FTEs) are } \\
\text { assigned to the Stormwater Construction } \\
\text { Inspection Program (inspectors enforcing } \\
\text { C.6)? }\end{array}$ & 4 in Engineering \\
\hline $\begin{array}{l}\text { 3. How many FTEs review erosion control } \\
\text { appropriateness and adequacy of proposed } \\
\text { Best Management Practices (BMPs) for each } \\
\text { site before issuing grading permits? }\end{array}$ & $1 \mathrm{FTE}$ review erosion control plans \\
\hline $\begin{array}{l}\text { 4. Employees who review erosion control } \\
\text { plans work for which department? }\end{array}$ & $\begin{array}{l}\text { Public Works Department Engineering/Current } \\
\text { Development section. }\end{array}$ \\
\hline $\begin{array}{l}\text { 5. Do the employees who review erosion } \\
\text { control plans also conduct inspections? }\end{array}$ & $\begin{array}{l}\text { No, but sometimes if the inspectors are not } \\
\text { available. }\end{array}$ \\
\hline $\begin{array}{l}\text { 6. Are site one acre or more verified to have a } \\
\text { Notice of Intent (NOI) for permit coverage } \\
\text { under the Construction General Permit } \\
\text { (CGP)? } \\
\text { If so, by whom? }\end{array}$ & $\begin{array}{l}\text { Yes. } \\
\text { First by engineers prior to issuance of the } \\
\text { grading permit and then by Site Inspectors }\end{array}$ \\
\hline $\begin{array}{l}\text { 7. Are Storm Water Pollution Prevention Plans } \\
\text { (SWPPP) reviewed? } \\
\text { If so, by whom? }\end{array}$ & Yes by Engineers \\
\hline $\begin{array}{l}\text { 8. Is outreach to developers tracked? } \\
\text { If so, how much outreach was done to } \\
\text { developers in past fiscal year? }\end{array}$ & No \\
\hline $\begin{array}{l}\text { 9. Is training provided to Construction } \\
\text { Inspection Program employees? } \\
\text { If so how often? }\end{array}$ & $\begin{array}{l}\text { Yes, inspectors either have a QSP certification } \\
\text { or are in the process of obtaining one. } \\
\text { Training is ongoing until you receive your QSP } \\
\text { certification and then after to maintain the } \\
\text { mandatory underlying certifications }\end{array}$ \\
\hline $\begin{array}{l}\text { What challenges does your program have } \\
\text { implementing MRP requirements? }\end{array}$ & $\begin{array}{l}\text { There are many challenges encountered during } \\
\text { review and during construction. BMP } \\
\text { implementation, adhere to SWPPP for the site, } \\
\text { maintenance of the SWPPP during rainy } \\
\text { season. }\end{array}$ \\
\hline
\end{tabular}




\section{City of Berkeley}

\section{Table 31: City of Berkeley Legal Authority}

City of Berkeley
$\mathbf{1 7 . 2 0 . 0 7 0 ~ D i s c h a r g e ~ o f ~ a n y ~ m a t t e r s ~ i n ~ v i o l a t i o n ~ o f ~ a n ~ N P D E S ~ p e r m i t ~ a n d ~ f a i l u r e ~ t o ~ o t h e r w i s e ~}$
comply with requirements pertaining to NPDES permits unlawful
A. It is unlawful to discharge any matter into the storm drain system such that the discharge results in
or contributes to a violation of any National Pollutant Discharge Elimination System (NPDES) permit
issued to the discharger and administered by the state of California under authority of the U.S.
Environmental Protection Agency, including the NPDES permit issued to the City of Berkeley and
others (NPDES Permit No. CA0029831, on file in the office of the City Clerk) and any amendment,
revision or reissuance thereof, and whether such discharge is separately considered or when
combined with other discharges.
B. Each industrial discharger, discharger associated with construction activity, or any other discharger
described in any general NPDES permit regulating stormwater discharges, as may be adopted by the
U.S. Environmental Protection Agency, the State Water Resources Control Board, or the California
Regional Water Quality Control Board, San Francisco Bay Region, shall submit to the appropriate
agency a notice of intent to comply with said permit and undertake all other activities required by any
general stormwater permit applicable to such discharges.
C. Each discharger identified in any individual NPDES permit regulating stormwater discharges shall
comply with and undertake all activities required by such permit. (Ord. 6216-NS $\S 7,1993$ )

Source: Berkeley, 2017

Table 32: City of Berkeley Construction Violations 2016

\begin{tabular}{|l|l|l|}
\hline City of Berkeley & Number of Violation & Percentage of Violation \\
\hline BMP Category & & \\
\hline Erosion Control & 0 & $0 \%$ \\
\hline Run-On \& Run Off Control & 0 & $0 \%$ \\
\hline Sediment Control & 2 & $50 \%$ \\
\hline Active Treatment Systems & 0 & $0 \%$ \\
\hline Good Site Management & 2 & $50 \%$ \\
\hline Non Stormwater Management & 0 & $0 \%$ \\
\hline Total & 4 & $100 \%$ \\
\hline
\end{tabular}

Source: Berkeley, 2016

\section{Table 33: City of Berkeley Minimum Qualifications}

\begin{tabular}{|l|}
\hline City of Berkeley \\
\hline Engineering Inspector \\
\hline$\$ 40.04$ - $\$ 48.20$ \\
\hline$-\quad$ Equivalent to graduation from high school \\
Completion of course in mechanical drawing and two years of experience in municipal \\
engineering or construction which included experience in construction inspection, \\
surveying or drafting \\
- $\begin{array}{l}\text { Course in computer aided design (CAD) programs such as AutoCAD or related } \\
\text { programs is desirable } \\
\text { Must be willing to work outdoors and to travel to various locations to meet program } \\
\text { needs and fulfill job responsibilities }\end{array}$ \\
\hline
\end{tabular}


- Maintain valid driver's license and satisfactory driving record

Source: Berkeley, 2017

Berkeley did not submit answers to questionnaire.

\section{City of Richmond}

\section{Table 34: City of Richmond Legal Authority}

\section{City of Richmond \\ 17.22.060 PROHIBITED DISCHARGES}

(a) The release of non-stormwater discharges to the City stormwater system and watercourses is prohibited.

(b) The discharge of stormwater from premises or an activity that causes or contributes to a violation

of receiving water limitations in the City's NPDES permit is prohibited.

(c) The following discharges are exempt from the prohibition set forth in subsection (a) above:

(1) Any discharge in compliance with a NPDES permit issued to the discharger; and

(2) Flows from riparian habitats and wetlands, diverted stream flows, springs, rising groundwater and uncontaminated groundwater infiltration.

(d) The following discharges are exempt from the prohibition set forth in subsection (a) above if and only if the discharges are in accordance with the specific conditions for each type of discharge set forth in Section C.15 of the City's NPDES permit: pumped groundwater from non-drinking-water aquifers; pumped groundwater from other sources, foundation drains, and water from crawl space pumps and footing drains; air conditioning condensate; planned discharges from routine operation and maintenance activities in the potable water distribution system; unplanned discharges from breaks, leaks, overflows, fire hydrant shearing, or emergency flushing of the potable water distribution system; emergency discharges of the potable water distribution system as a result of firefighting, unauthorized hydrant openings, or natural or man-made disasters; individual residential car washing; swimming pool, hot tub, spa, and fountain water discharges, and discharges from irrigation water, landscape irrigation, and lawn or garden watering.

(Ord. No. 17-13 N.S., § I, 9-17-2013)

\subsubsection{Discharge in Violation of NPDES Permit}

Any discharge that would result in or contribute to a violation of the City's NPDES permit either separately considered or when combined with other discharges, is prohibited. Liability for any such discharge shall be the responsibility of the person causing or responsible for the discharge, and such person shall defend, indemnify and hold harmless the City in any administrative or judicial enforcement action relating to such discharge.

(Ord. No. 17-13 N.S., § I, 9-17-2013)

\subsubsection{Best Management Practices and Standards}

(a) Generally. Any person owning or operating premises that may contribute pollutants to the City's stormwater system shall undertake best management practices to reduce the potential for pollutants entering the system to the maximum extent practicable. Examples of such premises include, but are not limited to, parking lots, gasoline stations, industrial facilities, paved private streets or roads, and other commercial enterprises. The City reserves the right to permit facilities that potentially contribute pollutants to stormwater, and to require business to hold polluted stormwater from entering the City municipal stormwater system when the City may violate its NPDES permit until the discharge meets accepted discharge standards.

(b) Litter. No person shall throw, deposit, leave, keep or permit to be thrown, deposited, placed, left or maintained, any refuse, rubbish, garbage or other discarded or abandoned objects, articles or other litter in or upon any street, alley, sidewalk, business place, creek, stormwater system, fountain, pool, lake, stream, river or any other body of water, or upon any public or private parcel of land so that the same might become a pollutant, except in containers or in lawfully established waste disposal facilities.

(c) Covered Loads. No person shall drive or move any vehicle with an open cab/trailer within the City 
unless such contents are secured by a tarp over the contents or the material being transported is constructed and loaded to ensure that all litter is prevented from being blown or deposited upon any street, alley or other public or private place.

(d) Sidewalks. The occupant or tenant, or in the absence of occupant or tenant, the owner or proprietor of any real property in front of which there is a paved sidewalk shall maintain said sidewalk free of dirt or litter to the maximum extent practicable. Sweepings from the sidewalk shall not be swept or otherwise made or allowed to go into the gutter or roadway, but shall be disposed of in receptacles maintained as required for the disposal of solid waste.

(e) Parking Lots, Paved Areas and Related Stormwater Systems. Persons owning, operating or maintaining a paved parking lot, the paved areas of a gasoline station, a paved private street or road, and related stormwater systems shall clean those premises as frequently and thoroughly as practicable in a manner that does not result in the discharge of pollutants to the City's stormwater system.

(f) Maintenance of Facilities and Landscaped Areas. Best management practices shall be implemented to minimize the release of pesticides, herbicides, and other related materials used to maintain landscaping and facilities.

(g) Construction Activities. All construction shall conform to the requirements of the CASQA Stormwater Best Management Practices Handbooks for Construction Activities and New Development and Redevelopment, the ABAG Manual of Standards for Erosion and Sediment Control Measures, the City's grading and erosion control ordinance and other generally accepted engineering practices for erosion control as required by the City Manager when undertaking construction activities. The City Manager may establish controls on the rate of stormwater runoff from new developments and redevelopment as may be appropriate to minimize the discharge and transport of pollutants. (h) Notification of Intent and Compliance with General Permits. Each discharger associated with construction activity or other discharger described in any general stormwater permit addressing discharges, as may be adopted by the United States Environmental Protection Agency, the State Water Resources Control Board, or the California Regional Water Quality Control Board, San Francisco Bay Region, shall provide the City Manager with the notice of intent, comply with and undertake all other activities required by any general stormwater permit applicable to such dischargers. Each discharger identified in an individual NPDES permit relating to stormwater discharges shall comply with and undertake all activities required by the permit.

(i) Development Runoff Requirements. For each new development and redevelopment project subject to the development runoff requirements, every applicant will submit a stormwater control plan and implement conditions of approval that reduce stormwater pollutant discharges through the construction, operation and maintenance of treatment measures and other appropriate source control and site design measures. Similarly, increases in runoff volume and flows shall be managed in accordance with the development runoff requirements.

(j) Compliance with Best Management Practices. Where best management practices guidelines or requirements have been adopted by any Federal, State, regional, City or County agency, for any activity, or operation of premises which may cause or contribute to non-stormwater discharges, every person undertaking such activity, operation or owning and operating such premises shall comply with such guidelines or requirements. Failure to implement and maintain best management practices included in a stormwater permit are subject to administrative citations.

(k) Stormwater Pollution Prevention Plan. The City Manager may require any business or utility in the City that is engaged in activities that may result in non-stormwater discharges or runoff pollutants to develop and implement a stormwater pollution prevention plan, which must include an employee training program. Business activities which may require a stormwater pollution prevention plan include maintenance, storage, manufacturing, assembly, equipment operations, vehicle loading, fueling, vehicle maintenance, food handling or processing, or cleanup procedures which are carried out partially or wholly out of doors. Failure to implement and maintain best management practices included in a stormwater pollution prevention plan are subject to administrative citations.

(I) Coordination with Hazardous Material Release Response and Inventory Plans. Any business subject to the Hazardous Material Release Response and Inventory Plan, Division 20, Chapter 6.95 of the California Health and Safety Code (commencing with Section 25500), shall include, in that plan, provision for compliance with this chapter, including the prohibitions of non-stormwater discharges and the requirement to reduce release of pollutants to the maximum extent practicable. 
(Ord. No. 17-13 N.S., § I, 9-17-2013)

17.22.110 Authority to Inspect

(a) Generally. Routine scheduled or unannounced inspections shall be based upon as reasonable a selection process as may be deemed necessary to carry out the intent of this chapter, including, but not limited to, random sampling or sampling in areas with evidence of stormwater contamination, evidence of the discharge of non-stormwater to the stormwater system, or similar activities. Inspections may also be conducted in conjunction with routine scheduled or unannounced inspections conducted by other public agencies or special district, including but not limited to the Central Contra Costa Sanitary District, the Contra Costa County Fire Protection District, County Environmental Health Department, the Contra Costa Mosquito and Vector Control District, or the Regional Water Quality Control Board.

(b) Authority to Sample and Establish Sampling Devices. With the consent of the owner or occupant, or pursuant to a search or inspection warrant, any officer may establish on any property such devices as are necessary to conduct sampling or metering operations. During all authorized inspections, the officer may take any sample deemed necessary to aid in the pursuit of the inquiry or in the recordation of the activities on site.

(c) Notification of Spills. All persons in charge of the premises or responsible for emergency response for the premises have a responsibility to train premises' personnel and maintain notification procedures to ensure that immediate notification is provided to the City of Richmond [of] any suspected, confirmed or unconfirmed release of pollutants creating a risk of non-stormwater discharge into the City stormwater system.

As soon as any person in charge of the premises or responsible for emergency response for the premises has knowledge of any suspected, confirmed or unconfirmed release of non-stormwater discharge entering the City stormwater system, such person shall take all necessary steps to ensure the detection and containment and clean up of such release and shall notify the City of Richmond of the occurrence by telephoning the City Manager. This notification requirement is in addition to and not in lieu of other required notifications.

(d) Requirement to Test or Monitor. Any officer may require that any person engaged in any activity or owning or operating any premises that may cause or contribute to non-stormwater discharges, undertake such monitoring activities or analysis and furnish such reports as the officer may specify. The burden, including costs of these activities, analysis and reports shall bear a reasonable relationship to the need for the monitoring, analysis and reports and the benefits to be obtained. The recipient of such request shall undertake and provide the monitoring, analysis and reports required. (Ord. No. 17-13 N.S., § I, 9-17-2013)

\subsubsection{Acts Potentially Resulting in Violation of Federal Clean Water Act or Porter-Cologne} Act

Any person who violates any provision of this chapter, or the provisions of any permit issued pursuant to this chapter, or who releases a non-stormwater discharge, or who violates any cease and desist order, prohibition or effluent limitation, may also be in violation of the Federal Clean Water Act or the Porter-Cologne Act and may be subject to the enforcement provisions of those acts, including civil and criminal penalties. Any enforcement actions authorized pursuant to this chapter may also include notice to the violator of such potential liability pursuant to Federal or State law.

(Ord. No. 17-13 N.S., § I, 9-17-2013)

Source: Richmond, 2017 
Table 35: City of Richmond Construction Violations 2016

\begin{tabular}{|l|l|l|}
\hline City of Richmond & Number of Violation & Percentage of Violation \\
\hline BMP Category & & \\
\hline Erosion Control & 1 & $33.3 \%$ \\
\hline Run-On \& Run Off Control & 0 & $0 \%$ \\
\hline Sediment Control & 1 & $33.3 \%$ \\
\hline Active Treatment Systems & 0 & $0 \%$ \\
\hline Good Site Management & 1 & $33.3 \%$ \\
\hline Non Stormwater Management & 0 & $0 \%$ \\
\hline Total & 3 & $100 \%$ \\
\hline
\end{tabular}

Source: Richmond, 2016

\section{Table 36: City of Richmond Minimum Qualifications}

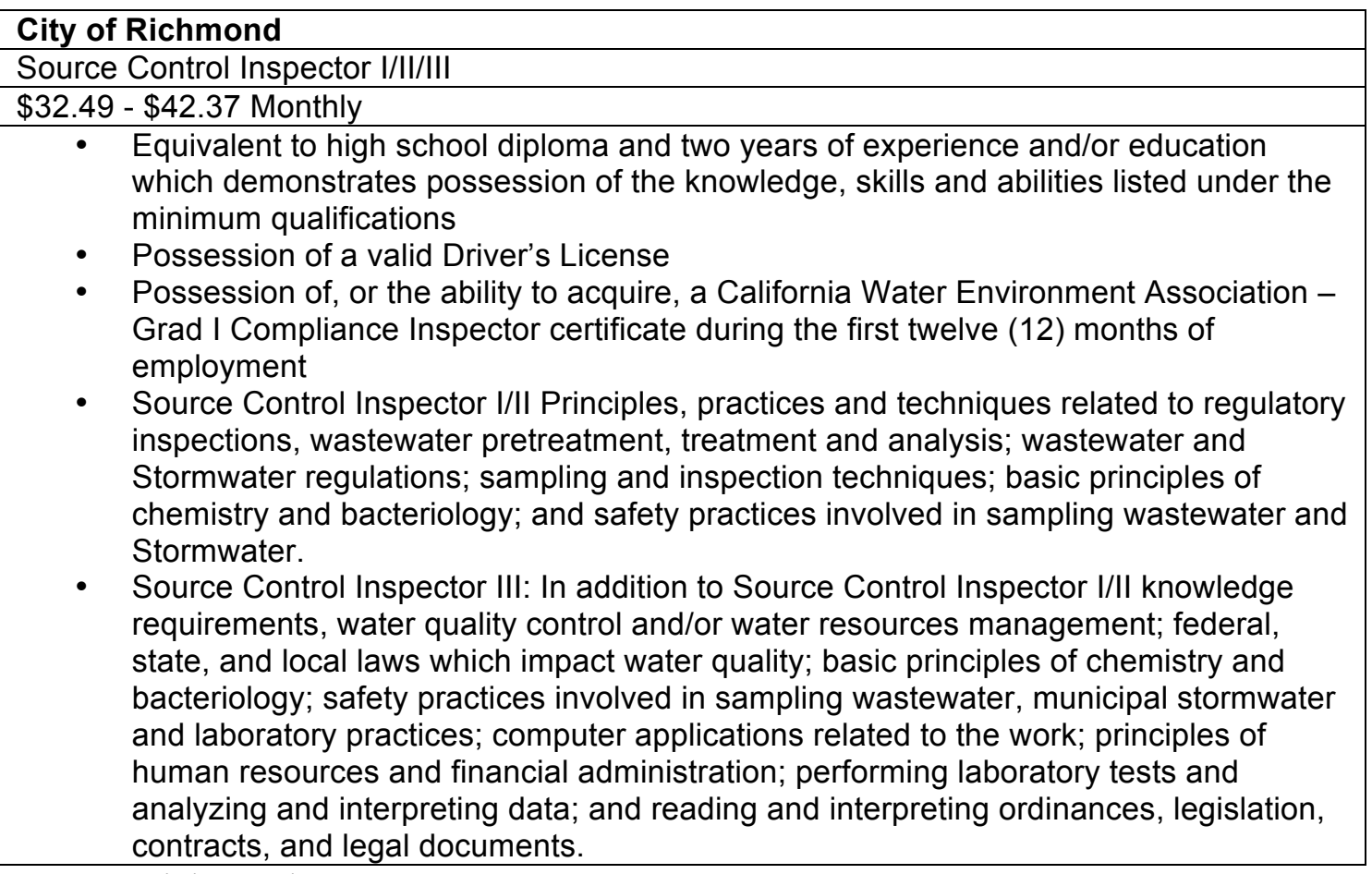

Source: Richmond, 2011 
Table 37: City of Richmond Questionnaire Results

\begin{tabular}{|c|c|}
\hline Questionnaire & City of Richmond \\
\hline $\begin{array}{l}\text { *Please answer questions best to your ability } \\
\text { and interpretation }\end{array}$ & \\
\hline $\begin{array}{l}\text { 1. Which departments are involved in the } \\
\text { issuing, review, and inspection of a grading } \\
\text { permit? }\end{array}$ & Planning \\
\hline $\begin{array}{l}\text { 2. How many full-time employees (FTEs) are } \\
\text { assigned to the Stormwater Construction } \\
\text { Inspection Program (inspectors enforcing } \\
\text { C.6)? }\end{array}$ & Two \\
\hline $\begin{array}{l}\text { 3. How many FTEs review erosion control } \\
\text { appropriateness and adequacy of proposed } \\
\text { Best Management Practices (BMPs) for each } \\
\text { site before issuing grading permits? }\end{array}$ & $\begin{array}{l}\text { The Department will recruit a FTE in an } \\
\text { Engineer position for plan review in this coming } \\
\text { year. }\end{array}$ \\
\hline $\begin{array}{l}\text { 4. Employees who review erosion control } \\
\text { plans work for which department? }\end{array}$ & Water Resource recovery \\
\hline $\begin{array}{l}\text { 5. Do the employees who review erosion } \\
\text { control plans also conduct inspections? }\end{array}$ & Yes \\
\hline $\begin{array}{l}\text { 6. Are site one acre or more verified to have a } \\
\text { Notice of Intent (NOI) for permit coverage } \\
\text { under the Construction General Permit } \\
\text { (CGP)? } \\
\text { If so, by whom? }\end{array}$ & $\begin{array}{l}\text { Yes. } \\
\text { The City does not review plans or issue } \\
\text { Grading/Stormwater permits unless projects } \\
\text { that are one or more acres submits a SWPPP } \\
\text { with WDID number issued from Waterboard. }\end{array}$ \\
\hline $\begin{array}{l}\text { 7. Are Storm Water Pollution Prevention Plans } \\
\text { (SWPPP) reviewed? } \\
\text { If so, by whom? }\end{array}$ & $\begin{array}{l}\text { Yes. } \\
\text { Currently, contract Engineer consultant. }\end{array}$ \\
\hline $\begin{array}{l}\text { 8. Is outreach to developers tracked? } \\
\text { If so, how much outreach was done to } \\
\text { developers in past fiscal year? }\end{array}$ & No \\
\hline $\begin{array}{l}\text { 9. Is training provided to Construction } \\
\text { Inspection Program employees? } \\
\text { If so how often? }\end{array}$ & $\begin{array}{l}\text { Yes } \\
\text { Annually }\end{array}$ \\
\hline $\begin{array}{l}\text { What challenges does your program have } \\
\text { implementing MRP requirements? }\end{array}$ & Funding and staffing \\
\hline
\end{tabular}




\section{City of Daly City}

\section{Table 38: City of Daly City Legal Authority}

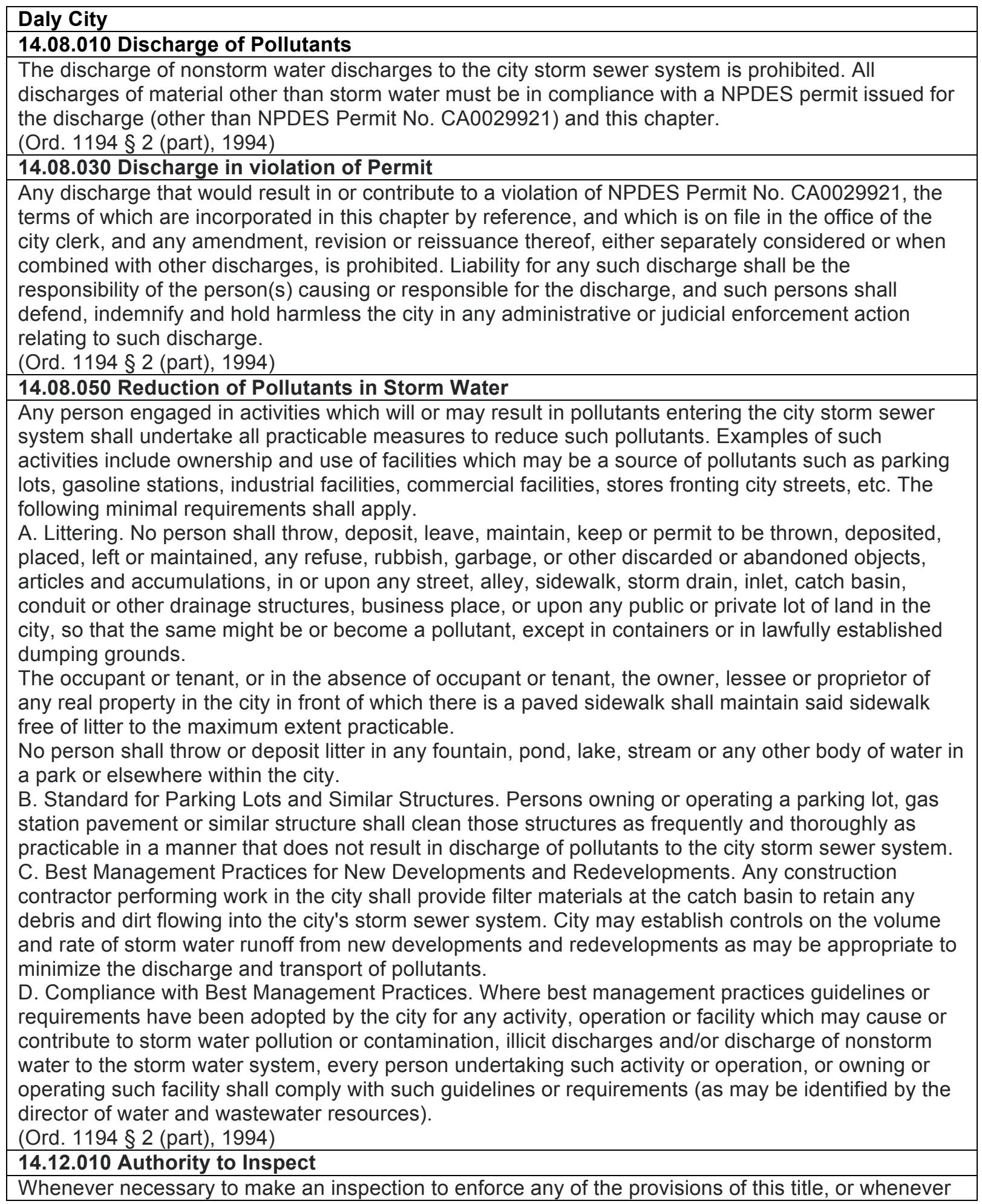


an authorized enforcement official has reasonable cause to believe that there exists in any building or upon any premises any condition which constitutes a violation of the provisions of this title, the official may enter such building or premises at all reasonable times to inspect the same or perform any duty imposed upon the official by this title; provided that $(A)$ if such building or premises be occupied, he or she shall first present proper credentials and request entry; and (B) if such building premises be unoccupied, he or she shall first make a reasonable effort to locate the owner or other persons having charge or control of the building or premises and request entry.

Any such request for entry shall state that the property owner or occupant has the right to refuse entry and that in the event such entry is refused, inspection may be made only upon issuance of a search warrant by a duly authorized magistrate. In the event the search owner and/or occupant refuses entry after such request has been made, the official is empowered to seek assistance from any court of competent jurisdiction in obtaining such entry.

Routine or area inspections shall be based upon such reasonable selection processes as may be deemed necessary to carry out the objectives of this title, including but not limited to random sampling and/or sampling in areas with evidence of storm water contamination, illicit discharges, discharge of nonstorm water to the storm water system, or similar factors.

(Ord. $1194 \S 3$ (part), 1994)

14.12.090 Administrative Enforcement Powers

In addition to the other enforcement powers and remedies established by this title, any authorized enforcement official has the authority to utilize administrative remedies.

(Ord. 1194 § 3 (part), 1994)

Source: Daly City, 2017

\section{Table 39: City of Daly City Construction Violations 2016}

\begin{tabular}{|l|l|l|}
\hline City of Daly City & Number of Violation & Percentage of Violation \\
\hline BMP Category & & \\
\hline Erosion Control & 0 & $0 \%$ \\
\hline Run-On \& Run Off Control & 0 & $0 \%$ \\
\hline Sediment Control & 1 & $33 \%$ \\
\hline Active Treatment Systems & 0 & $0 \%$ \\
\hline Good Site Management & 2 & $67 \%$ \\
\hline Non Stormwater Management & 0 & $0 \%$ \\
\hline Total & 3 & $100 \%$ \\
\hline
\end{tabular}

Source: Daly City, 2016

\section{Table 40: City of Daly City Minimum Qualifications}

\begin{tabular}{|l|l|}
\hline City of Daly City \\
\hline Public Works Inspector \\
\hline$\$ 39.90$ - $\$ 48.50$ \\
\hline - & Graduation from High School or equivalent \\
- & Poussears' public works inspection experience \\
& for two (2) years of experience \\
- A BS from an accredited college or university with major coursework in Civil Engineering \\
may be substituted for four (4) years of experience. \\
- Possession of a valid Class C California driver's license
\end{tabular}

Source: Daly City, 2007 


\section{Table 41: City of Daly City Questionnaire Results}

\begin{tabular}{|c|c|}
\hline Questionnaire & City of Daly City \\
\hline $\begin{array}{l}\text { *Please answer questions best to your ability } \\
\text { and interpretation }\end{array}$ & \\
\hline $\begin{array}{l}\text { 1. Which departments are involved in the } \\
\text { issuing, review, and inspection of a grading } \\
\text { permit? }\end{array}$ & Public Works - Engineering Division \\
\hline $\begin{array}{l}\text { 2. How many full-time employees (FTEs) are } \\
\text { assigned to the Stormwater Construction } \\
\text { Inspection Program (inspectors enforcing } \\
\text { C.6)? }\end{array}$ & $\begin{array}{l}\text { There are } 2 \text { FTE that do the C.6 required } \\
\text { inspections. }\end{array}$ \\
\hline $\begin{array}{l}\text { 3. How many FTEs review erosion control } \\
\text { appropriateness and adequacy of proposed } \\
\text { Best Management Practices (BMPs) for each } \\
\text { site before issuing grading permits? }\end{array}$ & Two \\
\hline $\begin{array}{l}\text { 4. Employees who review erosion control } \\
\text { plans work for which department? }\end{array}$ & Public Works \\
\hline $\begin{array}{l}\text { 5. Do the employees who review erosion } \\
\text { control plans also conduct inspections? }\end{array}$ & Yes \\
\hline $\begin{array}{l}\text { 6. Are site one acre or more verified to have a } \\
\text { Notice of Intent (NOI) for permit coverage } \\
\text { under the Construction General Permit } \\
(C G P) \text { ? } \\
\text { If so, by whom? }\end{array}$ & Yes, Public Works \\
\hline $\begin{array}{l}\text { 7. Are Storm Water Pollution Prevention Plans } \\
\text { (SWPPP) reviewed? } \\
\text { If so, by whom? }\end{array}$ & Yes. Currently, contract Engineer consultant. \\
\hline $\begin{array}{l}\text { 8. Is outreach to developers tracked? } \\
\text { If so, how much outreach was done to } \\
\text { developers in past fiscal year? }\end{array}$ & No \\
\hline $\begin{array}{l}\text { 9. Is training provided to Construction } \\
\text { Inspection Program employees? } \\
\text { If so how often? }\end{array}$ & $\begin{array}{l}\text { Yes, } \\
\text { Once every few years }\end{array}$ \\
\hline $\begin{array}{l}\text { What challenges does your program have } \\
\text { implementing MRP requirements? }\end{array}$ & $\begin{array}{l}\text { Facing more and more requirements with the } \\
\text { same staffing levels }\end{array}$ \\
\hline
\end{tabular}




\section{City of San Mateo}

\section{Table 42: City of San Mateo Legal Authority}

\section{City of San Mateo \\ 7.39.090 Discharge of Pollutants}

a) The discharge of non-stormwater discharges to the City storm drain system is prohibited. All discharges of material other than stormwater must be in compliance with a NPDES permit issued for the discharge (other than NPDES Permit No. CA0029921).

(b) The following discharges are exempt from the prohibition set forth in this section:

1) The prohibition on discharges shall not apply to any discharge regulated under a National Pollutant Discharge Elimination System (NPDES) permit issued to the discharger and administered by the State of California under authority of the United States Environmental Protection Agency, provided that the discharger is in full compliance with all requirements of the permit and other applicable laws or regulations.

(2) Discharges from the following activities will not be considered a source of pollutants to waters of the United States when properly managed: water line flushing and other discharges from potable water sources, landscape irrigation and lawn watering, irrigation water, diverted stream flows, rising ground waters, infiltration to separate storm drains, uncontaminated pumped groundwater, foundation and footing drains, water from crawl space pumps, air conditioning condensation, springs, individual residential car washings, flows from riparian habitats and wetlands, de-chlorinated swimming pool discharges or flows from fire fighting, and accordingly are not subject to the prohibition on discharges. (Ord. 2003-5 $\S 1$ )

\subsubsection{Discharge in Violation of Permit}

Any discharge that would result in or contribute to a violation of NPDES Permit No. CA0029921, the terms of which are incorporated herein by reference, and which is filed in the Office of the City Clerk, and any amendment, revision or reissuance thereof, either separately considered or when combined with other discharges, is prohibited. Liability for any such discharge shall be the responsibility of the person(s) causing or responsible for the discharge, and such persons shall defend, indemnify and hold harmless the City in any administrative or judicial enforcement action relating to such discharge, including attorneys' fees. (Ord. 2003-5 § 1)

\subsubsection{Reduction of Pollutants in Stormwater}

Any person engaged in activities, which will or may result in pollutants entering the City storm drain system shall undertake all practicable measures to reduce such pollutants. Examples of such activities include ownership and use of facilities which may be a source of pollutants such as parking lots, gasoline stations, industrial facilities, commercial facilities, stores fronting city streets, etc. The following minimal requirements shall apply:

(a) Littering. No person shall throw, deposit, leave, maintain, keep, or permit to be thrown, deposited, placed, left or maintained, any refuse, rubbish, garbage, or other discarded or abandoned objects, articles, and accumulations, in or upon any street, alley, sidewalk, storm drain, inlet, catch basin, conduit or other drainage structures, business place, or upon any public or private lot of land in the City, so that the same might be or become a pollutant, except in containers or in lawfully established dumping grounds. The occupant or tenant, or in the absence of occupant or tenant, the owner, lessee, or proprietor of any real property in the City of San Mateo in front of which there is a paved sidewalk shall maintain said sidewalk free of dirt or litter to the maximum extent practicable. Debris from said sidewalk shall not be swept or otherwise made or allowed to go into the gutter or roadway, but shall be disposed of in receptacles maintained on said real property as required for the disposal of garbage. No person shall throw or deposit litter in any fountain, pond, lake, stream or any other body of water in a park or elsewhere within the City.

(b) Standards for Parking Lots and Similar Structures. Persons owning or operating a parking lot, gas station pavement or similar structure shall clean those structures as frequently and thoroughly as practicable in a manner that does not result in discharge of pollutants to the City storm drain system.

(c) Best Management Practices for New Developments and Redevelopments. Any construction contractor performing work in the City shall endeavor, to provide filter materials at the catch basin to retain any debris and dirt flowing in to the City's storm drain system. The Director of Public Works may establish controls on the volume and rate of stormwater runoff from new developments and redevelopments as may 
be appropriate to minimize the discharge and transport of pollutants.

(d) Compliance with Best Management Practices. Where best management practices guidelines or requirements have been adopted by the City for any activity, operation, or facility which may cause or contribute to stormwater pollution or contamination, illicit discharges, and/or discharge of non-stormwater to the stormwater system, every person undertaking such activity or operation, or owning or operating such facility shall comply with such guidelines or requirements (as may be identified by the Director of Public Works). (Ord. 2003-5 § 1)

\subsubsection{Authority to Inspect and Monitor}

(a) Whenever necessary to make an inspection to enforce any of the provisions of this chapter, or whenever an authorized enforcement official has reasonable cause to believe that there exists in any building or upon any premises any condition which constitutes a violation of the provisions of this chapter, the official may enter such building or premises at all reasonable times to inspect the same or perform or have performed by others any duty imposed upon the official by this chapter; provided that: (1) if such building or premises be occupied, he or she shall first present proper credentials and request entry; and (2) if such building or premises be unoccupied, he or she shall first make a reasonable effort to locate the owner or other persons having charge or control of the building or premises and request entry.

(b) Any such request for entry shall state that the property owner or occupant has the right to refuse entry and that in the event such entry is refused, inspection may be made only upon issuance of a search warrant by a duly authorized magistrate. In the event the owner and/or occupant refuses entry after such request has been made, the official is hereby empowered to seek assistance from any court of competent jurisdiction in obtaining such entry.

(c) Routine or area inspections shall be based upon such reasonable selection processes as may be deemed necessary to carry out the objectives of this ordinance, including but not limited to random sampling and/or sampling in areas with evidence of stormwater contamination, illicit discharges, discharge of non-stormwater to the stormwater system, inspection of stormwater treatment facilities, or similar factors.

(d) The City shall have the right to establish on any property such devices as are necessary to conduct sampling or metering operations. During all inspections as provided herein, the official may take any samples deemed necessary to aid in the pursuit of the inquiry or in the recordation of the activities on-site. (Ord. 2003-5 § 1)

\subsubsection{Stormwater Pollution Prevention Construction Permit}

(a) No construction project as defined under Section 7.39.030, Definitions, conducted in or out of the public right-of-way that involves a land disturbance activity and that requires a site development planning application shall be approved without first obtaining a Stormwater Pollution Prevention Program construction (SWPPC) permit from the Director of Public Works.

(b) The Director of Public Works may require that a SWPPC permit be required for construction work involving a land disturbance activity that does not require a site development planning application, as may be necessary to carry out the purposes of this chapter. (Ord. 2003-5§1)

\subsubsection{Compliance with Chapter}

(a) Failure to comply with terms, conditions, or requirements of a stormwater pollution prevention permit, stormwater treatment facilities permit or maintenance agreement, compliance directive or other written notice, including, but not limited to, discharge standards, monitoring requirements, or reporting requirements, shall constitute noncompliance with this chapter. (b) The omission to act by the Director of Public Works and/or the failure of the Director of Public Works to take cognizance of the nature of the operation of the user and/or the properties of the user's discharge shall not relieve the user of the responsibility to comply with the provisions of this chapter. It is the responsibility of the user to make determinations as to the nature of its operation and waste discharge characteristics and to take such actions as may be required under this chapter prior to any discharge into any sanitary sewer system, whether or not the user has been informed by the Director of the requirements which may apply to the user regarding its discharge. (c) Liability for damages as a result of any discharges in violation of this chapter shall be the responsibility of the person(s) causing or responsible for the discharge, and such persons shall defend, indemnify, and hold harmless the City in any administrative or judicial enforcement action relating to such discharges. (Ord. 2003-5 § 1)

Source: Sam Mateo, 2017 
Table 43: City of San Mateo Construction Violations 2016

\begin{tabular}{|l|l|l|}
\hline City of San Mateo & Number of Violation & Percentage of Violation \\
\hline BMP Category & & \\
\hline Erosion Control & 0 & $0 \%$ \\
\hline Run-On \& Run Off Control & 0 & $0 \%$ \\
\hline Sediment Control & 0 & $0 \%$ \\
\hline Active Treatment Systems & 0 & $0 \%$ \\
\hline Good Site Management & 0 & $0 \%$ \\
\hline Non Stormwater Management & 0 & $0 \%$ \\
\hline Total & 0 & $0 \%$ \\
\hline
\end{tabular}

Source: San Mateo, 2016

\section{Table 44: City of San Mateo Minimum Qualifications}

\begin{tabular}{|c|c|}
\hline City of San Mateo \\
\hline Construction Inspector I \\
\hline$\$ 34.49-\$ 41.19$ \\
\hline$\bullet$ & Equivalent to completion of twelfth grade. \\
\hline & $\begin{array}{l}\text { Two years sub professional engineering or journey level public works or utility heavy } \\
\text { construction experience preferably including some construction inspection experience } \\
\text { or journey level survey work which also includes inspection work on projects. }\end{array}$ \\
\hline & Possession of, or ability to obtain, an appropriate, valid California driver's license \\
\hline & $\begin{array}{l}\text { Knowledge of: Principles, methods, materials, equipment and safety hazards of } \\
\text { construction and surveying, defects and faults in construction, basic mathematics } \\
\text { including algebra, geometry, and trigonometry and basic soil mechanics and geology }\end{array}$ \\
\hline
\end{tabular}

Source: San Mateo, 2002 


\section{Table 45: City of San Mateo Questionnaire Results}

\begin{tabular}{|c|c|}
\hline Questionnaire & City of San Mateo \\
\hline $\begin{array}{l}\text { *Please answer questions best to your ability } \\
\text { and interpretation }\end{array}$ & \\
\hline $\begin{array}{l}\text { 1. Which departments are involved in the } \\
\text { issuing, review, and inspection of a grading } \\
\text { permit? }\end{array}$ & $\begin{array}{l}\text { I think that the planning and building } \\
\text { departments are involved. Our construction } \\
\text { inspectors would be the ones to observe the } \\
\text { site. }\end{array}$ \\
\hline $\begin{array}{l}\text { 2. How many full-time employees (FTEs) are } \\
\text { assigned to the Stormwater Construction } \\
\text { Inspection Program (inspectors enforcing } \\
\text { C.6)? }\end{array}$ & $\begin{array}{l}\text { I think that we have } 3 \text { full time construction } \\
\text { inspectors }\end{array}$ \\
\hline $\begin{array}{l}\text { 3. How many FTEs review erosion control } \\
\text { appropriateness and adequacy of proposed } \\
\text { Best Management Practices (BMPs) for each } \\
\text { site before issuing grading permits? }\end{array}$ & I'm not sure \\
\hline $\begin{array}{l}\text { 4. Employees who review erosion control } \\
\text { plans work for which department? }\end{array}$ & Planning \\
\hline $\begin{array}{l}\text { 5. Do the employees who review erosion } \\
\text { control plans also conduct inspections? }\end{array}$ & No \\
\hline $\begin{array}{l}\text { 6. Are site one acre or more verified to have a } \\
\text { Notice of Intent (NOI) for permit coverage } \\
\text { under the Construction General Permit } \\
(C G P) \text { ? } \\
\text { If so, by whom? }\end{array}$ & Yes, Planning \\
\hline $\begin{array}{l}\text { 7. Are Storm Water Pollution Prevention Plans } \\
\text { (SWPPP) reviewed? } \\
\text { If so, by whom? }\end{array}$ & $\begin{array}{l}\text { Yes. Planning, and I have reviewed a few for } \\
\text { City facilities }\end{array}$ \\
\hline $\begin{array}{l}\text { 8. Is outreach to developers tracked? } \\
\text { If so, how much outreach was done to } \\
\text { developers in past fiscal year? }\end{array}$ & Not that I'm aware of \\
\hline $\begin{array}{l}\text { 9. Is training provided to Construction } \\
\text { Inspection Program employees? } \\
\text { If so how often? }\end{array}$ & $\begin{array}{l}\text { Yes. We have C. } 6 \text { workshops that happen at } \\
\text { least annually. }\end{array}$ \\
\hline $\begin{array}{l}\text { What challenges does your program have } \\
\text { implementing MRP requirements? }\end{array}$ & $\begin{array}{l}\text { Revising related policy and planning } \\
\text { documents to reflect changes in the MRP. }\end{array}$ \\
\hline
\end{tabular}




\title{
City San Leandro
}

\section{Table 46: City of San Leandro Legal Authority}

\author{
City of San Leandro \\ 3-15-200 Discharge Pollutants \\ The discharge of non-storm water discharges to the City storm sewer system is prohibited. All discharges \\ of material other than storm water must be in compliance with a NPDES permit issued for the discharge \\ (other than NPDES Permit No. CA0029831) \\ (a) Exceptions to Discharge Prohibition: The following discharges are exempt from the prohibition set \\ forth in Section 3-15-200 above: \\ (1) Any discharge regulated under a NPDES permit issued to the discharger and administered by the \\ State of California under authority of the United States Environmental Protection Agency, provided that \\ the discharger is in full compliance with all requirements of the permit and other applicable laws or \\ regulations. \\ (2) Discharges from the Following Activities When Properly Managed: water line flushing and other \\ discharges from potable water sources, landscape irrigation and lawn watering, irrigation water, diverted \\ stream flows, rising ground waters, infiltration to separate storm drains, uncontaminated pumped ground \\ water, foundation and footing drains, water from crawl space pumps, air conditioning condensation, \\ springs, individual residential car washings, flows from riparian habitats and wetlands, dechlorinated \\ swimming pool discharges, or flows from fire fighting.
}

\section{3-15-205 Discharge in Violation of Permit}

Any discharge that would result in or contribute to a violation of NPDES Permit No. CA0029831, and, of any amendment, revision, or reissuance thereof, either separately considered or when combined with other discharges, is prohibited. Liability for any such discharge shall be the responsibility of the person(s) causing or responsible for the discharge, and such persons shall defend, indemnify, and hold harmless the City in any administrative or judicial enforcement action relating to such discharge.

\section{3-15-215 Reduction of Pollutants in Storm Water}

Any person engaged in activities which will or may result in pollutants entering the City storm sewer system shall undertake all practicable measures to reduce such pollutants. The following minimal requirements shall apply.

(a) Littering: Except when deposited into containers or in lawfully established dumping grounds, no person shall throw, deposit, leave, maintain, keep, or permit to be thrown, deposited, placed, left, or maintained, any refuse, rubbish, garbage, or other discarded or abandoned objects, articles, and accumulations, in or upon any street, alley, sidewalk, storm drain, inlet, catch basin, conduit, or other drainage structures, business place, or upon any public or private lot of land in the City, so that the same might be or become a pollutant. The occupant or tenant, or in the absence of occupant or tenant, the owner, lessee, or proprietor, of any real property in the City of San Leandro in front of which there is a paved sidewalk shall maintain said sidewalk free of dirt or litter to the maximum extent practicable. Sweepings from said sidewalk shall not be swept or otherwise made or allowed to go into the gutter or roadway, but shall be disposed of in receptacles maintained on said real property as required for the disposal of garbage.

No person shall throw or deposit litter in any fountain, pond, lake, stream, or any other body of water within the City.

(b) Standard for Parking Lots and Similar Structures: Persons owning or operating a parking lot, gas station pavement, or similar structure shall clean those structures as frequently and thoroughly as practicable in a manner that does not result in discharge of pollutants to the City storm sewer system.

(c) Best Management Practices for New Developments and Redevelopments: Any construction contractor performing work in the City shall endeavor, whenever possible, to provide filter materials at the catch basin to retain any debris and dirt flowing into the City's storm sewer system. The City Engineer may establish controls on the volume and rate of storm water runoff from new developments and redevelopments as may be appropriate to minimize the discharge and transport of pollutants.

(d) Compliance with Best Management Practices: Where best management practices guidelines or 
requirements have been adopted by any Federal, State of California, regional, and/or City agency, for any activity, operation, or facility which may cause or contribute to storm water pollution or contamination, illicit discharges, and/or discharge of non-storm water to the storm water system, every person undertaking such activity or operation, or owning or operating such facility, shall comply with such guidelines or requirements.

\section{3-18-125 Authority to Inspect}

Whenever necessary to make an inspection to enforce any provisions of this Title 3 or whenever the City Manager has reasonable cause to believe that there exists in any building or upon any premises any condition which constitutes a violation of the provisions of this Title, the City Manager may enter such building or premises at all reasonable times to inspect the same or perform any duty imposed upon the City Manager by this Title; provided that: (1) if such building or premises be occupied, he or she shall first present proper credentials and request entry; and (2) if such building or premises be unoccupied, he or she shall first make a reasonable effort to locate the owner or other persons having charge or control of the building or premises and request entry.

Any such request for entry shall state that the property owner or occupant has the right to refuse entry and that in the event such entry is refused, inspection may be made only upon issuance of an inspection or search warrant by a duly authorized magistrate. In the event the owner or occupant refuses entry after such request has been made, or in the event that the owner or person in charge of the building or premises cannot be located, an inspection/ abatement or search warrant authorizing entry shall be obtained prior to City's entry onto the building or premises. The City Manager is hereby empowered to seek assistance from any court of competent jurisdiction in obtaining such warrant authorizing entry.

Routine or area inspections shall be based upon such reasonable selection processes as may be deemed necessary to carry out the objectives of this Title 3.

(a) Authority to Sample and Establish Sampling Devices. The City shall have the right to establish on any property such devices as are necessary to conduct sampling or monitoring operations. During all inspections as provided herein, the City Manager may take any samples deemed necessary to aid in the pursuit of the inquiry or in the recordation of the activities on-site.

(b) Notification of Spills. As soon as any person in charge of a facility or responsible for emergency response for a facility has knowledge of any confirmed or unconfirmed release of materials, pollutants or waste, such person shall take all necessary steps to ensure the discovery and containment and clean-up of such release and shall notify the City of the occurrence by telephoning the City Manager and confirming the notification by correspondence to the same.

(c) Requirement to Test or Monitor. The City Manager may request that any person engaged in any activity and/or owning or operating any facility which may cause or contribute to storm water pollution, contamination, illicit discharges, discharge of non-storm water to the storm water system, and/or release, discharge or deposit of hazardous materials shall undertake such monitoring activities and/or analyses and furnish such reports as the City Manager may specify. The burden, including costs, of these activities, analyses, and reports shall bear a reasonable relationship to the need for the monitoring, analyses, and reports and the benefits to be obtained. The recipient of such request shall undertake and provide the monitoring, analyses and/or reports requested.

\section{3-18-175 Acts Potentially Resulting in Violation of Federal Clean Water Act and/or Porter-Cologne} Act

Any person who violates any provision of this Chapter, any provision of any permit issued pursuant to this Chapter, or who discharges waste or wastewater which causes pollution, or who violates any cease and desist order, prohibition, or effluent limitation, may also be in violation of the Federal Clean Water Act and/or Porter-Cologne Act and may be subject to the sanctions of those Acts including civil and criminal penalties. Any enforcement action authorized under this Article shall also include notice to the violator of such potential liability.

\section{7-12-600 General Requirements Applicable for All Grading Work Unless Modified by the City} Engineer

The following shall apply to all grading work unless otherwise specified in the soils report and grading plan by the applicant's civil engineer in charge which has been approved by the City Engineer or his duly authorized representatives: 
(a) Grading, erosion control, sedimentation and pollutant control work shall be done in accordance with plans hereinbefore described.

(b) No grading work shall be done during the wet season unless specifically permitted in writing by the City Engineer.

(c) Temporary erosion and sedimentation control facilities shall be completely in place prior to October 15th, and shall be diligently maintained to ensure effectiveness through April 15th.

(d) The hours of grading operations shall be only between 7:00 a.m. to 6:00 p.m. (Monday-Saturday) unless otherwise specified by the City Engineer or his authorized representative. No grading shall be done on Sundays except if authorized by the City Engineer for reasons of public safety.

(e) No clearing and grubbing shall take place on any site for which a grading permit is required prior to the issuance of a valid grading permit.

(f) Where a tree removal permit is required by this Code, no tree removal shall take place if a grading permit is required until both permits have been granted.

(g) No grading shall be approved on properties adjacent to the site without the written permission of the adjacent property owner. Such written permission shall be notarized and acknowledged and presented to the City Engineer as part of the items required with the application for grading permit.

(h) The rate of slope of the surface of permanent fills shall not be steeper than two to one (2:1) and the rate of slope of permanent cut slopes, shall not be steeper than one and one-half to one (1 1/2:1), unless otherwise recommended in the soils report and approved in writing by the City Engineer.

(i) Drainage facilities shall be provided to convey storm waters to a natural watercourse, swale or other drainage way, or to a public storm drainage system at locations and in a manner satisfactory to the City Engineer. Adequate measures shall be taken to control storm waters during grading operations. The quality of storm water from the site shall be as required in the "Storm Water Management and Discharge Control Program Ordinance." The current "Storm Water Quality Controls for New Developments in Santa Clara Valley and Alameda County," otherwise known as the Best Management Practices Manual, shall serve as a guide to achieving the required storm water quality.

(j) Erosion control shall include planting of all graded areas to be left exposed to the elements in accordance with the planned maintenance of such areas.

(k) No grading shall be done which will cause sloughing of materials from or onto adjoining property.

(I) Applicant shall not dump, move or place any earth, sand, gravel, rock, stone or other excavated material so as to cause the same to be deposited upon or to roll, flow or wash upon or over the premises of another without the express consent of the owner of such premises so affected or upon or over any public place or way.

(m) Applicant shall not, when hauling any earth, sand, gravel, rock, stone, or other excavated material over any public street, alley or other public place, allow such material to blow or spill over and upon such street, alley, or place or adjacent private property.

$(n)$ If due to a violation of subsections $(I)$ and $(m)$ of this section, any earth, sand, gravel, rock, stone or other excavated material is caused to be deposited upon or to roll, flow or wash upon any public place or way, the applicant therefor shall cause the same to be removed from such public place or way within thirty-six (36) hours. In the event it is not so removed, the City Engineer shall cause such removal and the cost of such removal by the City Engineer shall be paid to the City by the applicant who failed to so remove the material.

(o) Applicant shall not excavate on land sufficiently close to the property line to endanger any adjoining public street, sidewalk, alley or the public property without supporting and protecting such public street, sidewalk, alley or other public property from settling, cracking, or other damage which might result from such excavation. Should the nature of the excavation in the opinion of the City Engineer create a hazard to life unless adequately fenced, the applicant shall construct such fences or guard rails to safeguard persons using the public street, sidewalk, alley or other public property as the City Engineer may require.

(p) If at any stage of work on an excavation or fill the City Engineer determines by inspection that the nature or the formation is such that further work as authorized by an existing permit is likely to endanger any property or public way, the City Engineer may require as a condition to allowing further work to be done that such reasonable safety precautions be taken as the City Engineer considers necessary to avoid such likelihood of danger. Such safety precautions may include, but shall not be limited to, specifying a flatter exposed slope, construction of additional drainage facilities, berms, terracing, compaction or cribbing.

Source: San Leandro, 2017 


\section{Table 47: City of San Leandro Construction Violations 2016}

\begin{tabular}{|l|l|l|}
\hline City of San Leandro & Number of Violation & Percentage of Violation \\
\hline BMP Category & & \\
\hline Erosion Control & 0 & $0 \%$ \\
\hline Run-On \& Run Off Control & 0 & $0 \%$ \\
\hline Sediment Control & 0 & $0 \%$ \\
\hline Active Treatment Systems & 0 & $0 \%$ \\
\hline Good Site Management & 0 & $0 \%$ \\
\hline Non Stormwater Management & 0 & $0 \%$ \\
\hline Total & 0 & $0 \%$ \\
\hline
\end{tabular}

Source: San Leandro, 2016

\section{Table 48: City of San Leandro Minimum Qualifications}

\begin{tabular}{|l|l|}
\hline City of San Leandro \\
\hline Engineering Inspector \\
\hline$\$ 37.13$ - $\$ 45.13$ \\
\hline - & High School diploma or equivalent (GED) \\
- & Willing to work' recent experience foreman-level construction or engineering duties. \\
& California driver's license. \\
- & Knowledge of construction methods and the uses and properties of construction \\
materials; Proper and safe usage of all applicable testing and inspection equipment; \\
materials testing and evaluation; applicable Federal and state laws, City ordinances and \\
department policies and procedures. Proper English usage, including spelling, grammar \\
and syntax, punctuation \\
and vocabulary. \\
\hline
\end{tabular}

Source: San Leandro, 2015 
Table 49: City of San Leandro Questionnaire Results

\begin{tabular}{|c|c|}
\hline Questionnaire & City of San Leandro \\
\hline $\begin{array}{l}\text { *Please answer questions best to your ability } \\
\text { and interpretation }\end{array}$ & \\
\hline $\begin{array}{l}\text { 1. Which departments are involved in the } \\
\text { issuing, review, and inspection of a grading } \\
\text { permit? }\end{array}$ & $\begin{array}{l}\text { City of San Leandro Engineering \& } \\
\text { Transportation Department }\end{array}$ \\
\hline $\begin{array}{l}\text { 2. How many full-time employees (FTEs) are } \\
\text { assigned to the Stormwater Construction } \\
\text { Inspection Program (inspectors enforcing } \\
\text { C.6)? }\end{array}$ & $\begin{array}{l}\text { One Engineering Inspector conducts all } \\
\text { inspections for City of San Leandro. }\end{array}$ \\
\hline $\begin{array}{l}\text { 3. How many FTEs review erosion control } \\
\text { appropriateness and adequacy of proposed } \\
\text { Best Management Practices (BMPs) for each } \\
\text { site before issuing grading permits? }\end{array}$ & $\begin{array}{l}\text { The Land Development Section of Engineering } \\
\& \text { Transportation employs two Associated } \\
\text { Engineers who perform plan-check. Plan } \\
\text { check includes the review of stormwater BMP's } \\
\text { and Erosion Control Plans. }\end{array}$ \\
\hline $\begin{array}{l}\text { 4. Employees who review erosion control } \\
\text { plans work for which department? }\end{array}$ & Engineering and Transportation \\
\hline $\begin{array}{l}\text { 5. Do the employees who review erosion } \\
\text { control plans also conduct inspections? }\end{array}$ & $\begin{array}{l}\text { Yes. On a monthly basis, our Engineering } \\
\text { Inspector and Associate Engineer visit the sites } \\
\text { of active Grading Permits to review issues of } \\
\text { mutual interest. }\end{array}$ \\
\hline $\begin{array}{l}\text { 6. Are site one acre or more verified to have a } \\
\text { Notice of Intent (NOI) for permit coverage } \\
\text { under the Construction General Permit } \\
\text { (CGP)? } \\
\text { If so, by whom? }\end{array}$ & $\begin{array}{l}\text { Yes. We require the WDID number to be } \\
\text { printed on the grading plans. } \\
\text { By an Associate Engineer }\end{array}$ \\
\hline $\begin{array}{l}\text { 7. Are Storm Water Pollution Prevention Plans } \\
\text { (SWPPP) reviewed? }\end{array}$ & \\
\hline If so, by whom? & By an Associate Engineer \\
\hline $\begin{array}{l}\text { If so, how much outreach was done to } \\
\text { developers in past fiscal year? }\end{array}$ & $\begin{array}{l}\text { Yes. Letters are sent once a year to all } \\
\text { Grading Permit applicants informing them } \\
\text { about the requirements in advance of the rainy } \\
\text { season. } \\
\text { One letter was sent to each Grading Permit } \\
\text { applicant. }\end{array}$ \\
\hline $\begin{array}{l}\text { 9. Is training provided to Construction } \\
\text { Inspection Program employees? } \\
\text { If so how often? }\end{array}$ & $\begin{array}{l}\text { Yes } \\
\text { Typically once per year through the } \\
\text { Countywide Clean Water Act Program }\end{array}$ \\
\hline $\begin{array}{l}\text { What challenges does your program have } \\
\text { implementing MRP requirements? }\end{array}$ & Lack of adequate funding and staff. \\
\hline
\end{tabular}




\section{City of Livermore}

\section{Table 50: City of Livermore Legal Authority}

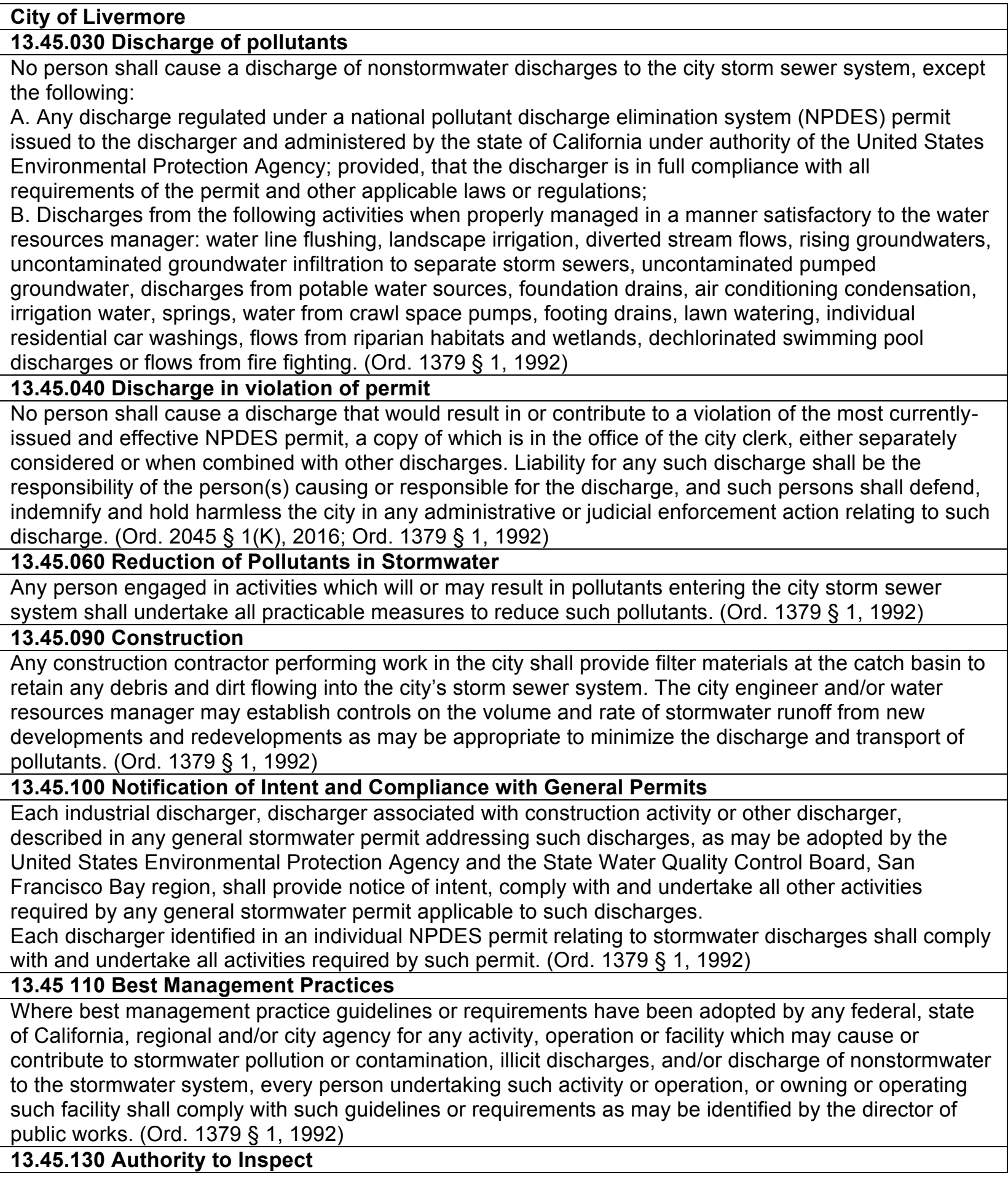




\begin{abstract}
A. Whenever necessary to make an inspection to enforce any of the provisions of this chapter, or whenever an authorized enforcement official has reasonable cause to believe that there exists in any building or upon any premises any condition which constitutes a violation of the provisions of this chapter, the official may enter such building or premises at all reasonable times to inspect the same or perform any duty imposed upon the official by this chapter; provided, that (1) if such building or premises is occupied, he or she shall first present proper credentials and request entry; and (2) if such building or premises is unoccupied, he or she shall first make a reasonable effort to locate the owner or other person having charge or control of the building or premises and request entry.

B. Any such request for entry shall state that the property owner or occupant has the right to refuse entry and that in the event such entry is refused, inspection may be made only upon issuance of a search warrant by a duly authorized magistrate. In the event the owner and/or occupant refuses entry after such request has been made, the official is hereby empowered to seek assistance from any court of competent jurisdiction in obtaining such entry.

C. Routine or area inspections shall be based upon such reasonable selection processes as may be deemed necessary to carry out the objectives of this chapter, including, but not limited to, random sampling and/or sampling in areas with evidence of stormwater contamination, illicit discharges, discharge of nonstormwater to the stormwater system, or similar factors. (Ord. $1379 \S 1,1992$ )

13.45.190 Administrative Enforcement Powers

In addition to the other enforcement powers and remedies established by this chapter, any authorized enforcement official has the authority to utilize the following administrative remedies:

A. When an authorized enforcement official finds that a discharge has taken place or is likely to take place in violation of this chapter, the official may issue an order to cease and desist such discharge, practice, or operation likely to cause such discharge and direct that those persons not complying shall:

1. Comply with the requirement;

2. Comply with a time schedule for compliance; and/or

3. Take appropriate remedial or preventive action to prevent the violation from recurring.

B. Whenever an authorized enforcement official finds any oil, earth, dirt, grass, weeds, dead trees, tin cans, rubbish, refuse, waste or any other material of any kind, in or upon the sidewalk abutting or adjoining any parcel of land or upon any parcel of land or grounds, which may result in an increase in pollutants entering the city storm sewer system, he or she shall give notice to remove such oil, earth, dirt, grass, weeds, dead trees, tin cans, rubbish, refuse, waste or other material, in any manner that he or she may reasonably provide. (Ord. $1379 \S 1,1992$ )
\end{abstract}

Source: Livermore, 2017

Table 51: City of Livermore Construction Violations 2016

\begin{tabular}{|l|l|l|}
\hline City of Livermore & Number of Violation & Percentage of Violation \\
\hline BMP Category & & \\
\hline Erosion Control & 0 & $0 \%$ \\
\hline Run-On \& Run Off Control & 0 & $0 \%$ \\
\hline Sediment Control & 13 & $45 \%$ \\
\hline Active Treatment Systems & 0 & $0 \%$ \\
\hline Good Site Management & 8 & $27.5 \%$ \\
\hline Non Stormwater Management & 8 & $27.5 \%$ \\
\hline Total & 29 & $100 \%$ \\
\hline
\end{tabular}

Source: Livermore, 2016 
Table 52: City of Livermore Minimum Qualifications

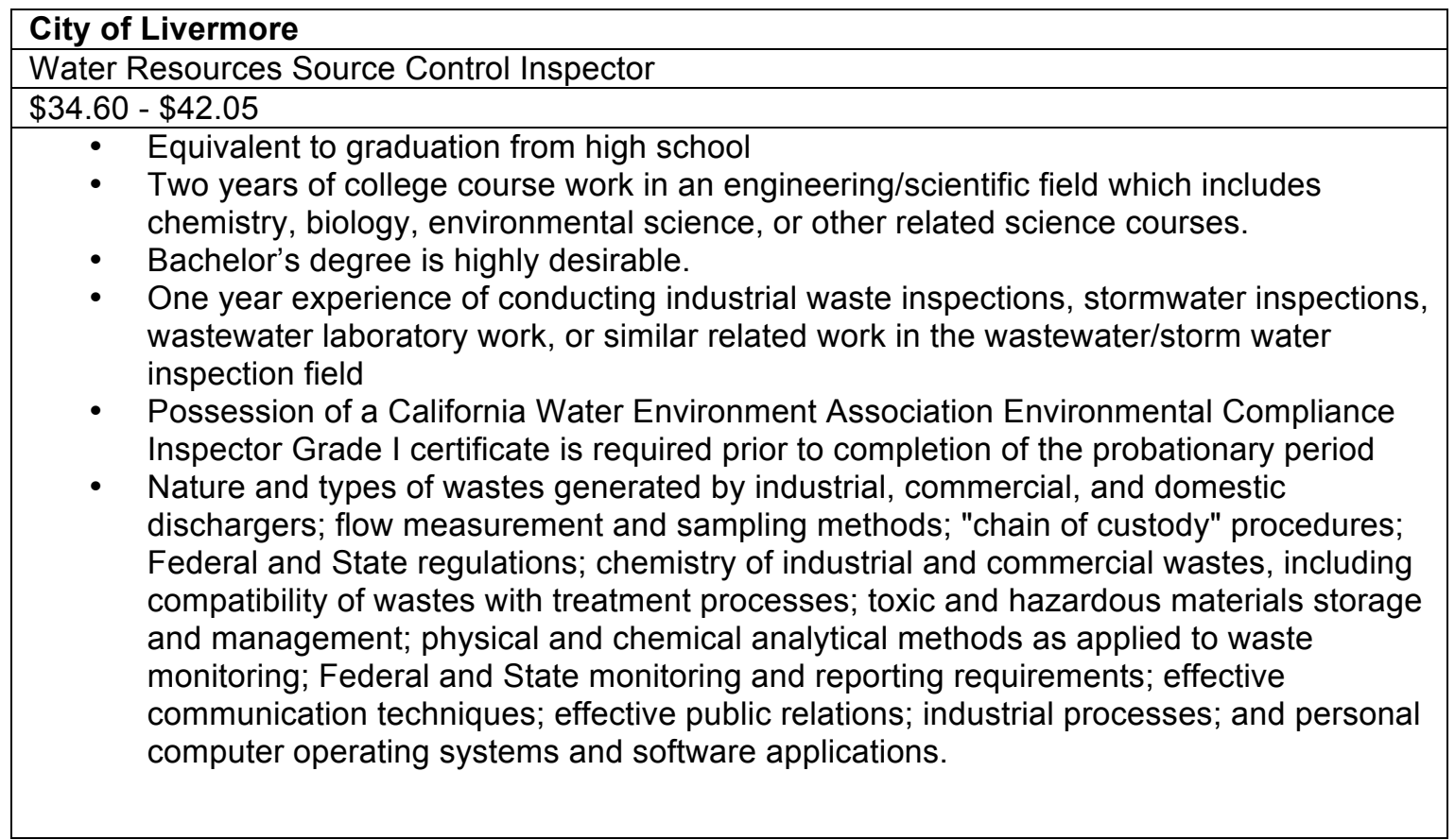

Source: Livermore, 2010

The City of Livermore did not submit answers to the questionnaire. 


\begin{abstract}
ANALYSIS
Using the documents cited in the Findings, a variety of data was analyzed to determine whether the fourteen municipalities studied were in compliance with the MRP requirements. The municipal codes were collected from all cities to determine whether each permittee has legal authority to enforce and inspect. The Enforcement Response Plans were requested and collected from all fourteen cities to confirm existence and compliance with MRP. Data from each annual report was collected and analyzed to determine whether permittees required construction sites to have BMPs in the categories outlined in the MRP. The questionnaire was used to determine whether permittees review erosion control plans, SWPPP, NOI, and provide training for staff as are required by the MRP.
\end{abstract}

Additional data was collected to determine what challenges permittees have implementing MRP requirements. Minimum Qualification from all fourteen cities were requested and collected to analyze the quality of inspector enforcing in Construction Inspection Programs. The annual report also provided feedback of self-evaluations of Construction Inspection Program Effectiveness from each permittee.

There was a trend of consistency among municipalities regarding municipal code. As shown in the tables above, all cities have code addressing discharge of pollutants. Each city has a code addressing authority to inspect, except for the City of San Jose. The City of Hayward has the most extensive municipal code addressing legal authority to enforce requirements of the MRP, followed by the City of Oakland. The City of San Jose has the most ambiguous code. All fourteen cities have an existing Enforcement Response Plan. The Enforcement Response Plan provides guidance to staff regarding compliance with C.6 of the MRP and enforcement of City ordinance and regulations (Berkeley, 2013; Concord, 2010; Daly City, 2016; Fremont, 2013; 
Hayward, 2016; Livermore, 2010; Oakland, 2013; Richmond, 2016, San Jose, 2014; San

Leandro, 2016; San Mateo, 2016; Santa Clara, 2013, Sunnyvale, 2013; Vallejo, 2015).

The City of Fremont, Oakland, San Jose, and Sunnyvale are the only cities to require a Bachelor's degree for the inspectors, as shown in Tables 53 and Table 54. Those cities that require a Bachelor's degree also require an emphasis in Science. Only two cities, Livermore and Richmond, require a professional certification upon hiring or during the probationary period. Most cities require two or more years of experience with inspection, excluding Richmond, San Jose, and Sunnyvale. The City of San Jose and Sunnyvale do not require inspection experience, but both cities have higher education standards. The City of Richmond does not require inspection experience but requires a professional certification. Five of the fourteen cities, (Concord, Fremont, San Jose, San Leandro and Santa Clara), require knowledge of environmental laws. The City of Santa Clara and Berkeley have the highest pay for inspectors and both cities have the least stringent requirements concerning education and knowledge of environmental laws. The City of Concord has the lowest pay for inspectors and does not require a Bachelor's degree, although it does require knowledge of environmental laws. 
Table 53: Summary of Education Minimum Qualification

\begin{tabular}{|c|c|c|c|c|}
\hline $\begin{array}{l}\text { Education } \\
\text { Minimum } \\
\text { Qualification }\end{array}$ & $\begin{array}{l}12^{\text {th }} \text { Grade } \\
\text { Equivalent }\end{array}$ & $\begin{array}{l}\text { Some } \\
\text { College }\end{array}$ & $\begin{array}{l}\text { Bachelor's } \\
\text { Degree }\end{array}$ & $\begin{array}{l}\text { Bachelor's } \\
\text { Degree with } \\
\text { Science } \\
\text { Emphasis }\end{array}$ \\
\hline City of San Jose & $\mathrm{X}$ & $\mathrm{X}$ & $\mathrm{X}$ & $\mathrm{X}$ \\
\hline City of Oakland & $\mathrm{X}$ & $X$ & $\mathrm{X}$ & $X$ \\
\hline City of Fremont & $\mathrm{X}$ & $\mathrm{X}$ & $\mathrm{X}$ & $X$ \\
\hline City of Hayward & $\mathrm{X}$ & & & \\
\hline City of Sunnyvale & $\mathrm{X}$ & $\mathrm{X}$ & $\mathrm{X}$ & $\mathrm{X}$ \\
\hline City of Concord & $\mathrm{X}$ & & & \\
\hline City of Santa Clara & $\mathrm{X}$ & & & \\
\hline City of Vallejo & $\mathrm{X}$ & $X$ & & \\
\hline City of Berkeley & $x$ & & & \\
\hline City of Richmond & $\mathrm{X}$ & & & \\
\hline City of Daly City & $\mathrm{X}$ & & & \\
\hline City of San Mateo & $\mathrm{X}$ & & & \\
\hline $\begin{array}{l}\text { City of San } \\
\text { Leandro }\end{array}$ & $\mathrm{X}$ & & & \\
\hline City of Livermore & $\mathrm{X}$ & $\mathrm{X}$ & & \\
\hline
\end{tabular}

Source: Berkeley, 2017; Concord, 2012; Daly City, 2007; Fremont, 2009; Hayward, 2015; Livermore, 2004; Oakland, 2014; Richmond, 2011; San Jose, 2001; San Leandro, 2015; San Mateo, 2002; Santa Clara, 2008; Sunnyvale, 2014; Vallejo, 2013

Table 54: Summary of Education, Experience, and Knowledge Qualifications

\begin{tabular}{|l|c|l|l|c|}
\hline $\begin{array}{l}\text { Summary of } \\
\text { Minimum } \\
\text { Qualifications }\end{array}$ & $\begin{array}{l}\text { Bachelor's } \\
\text { Degree with } \\
\text { Science } \\
\text { Emphasis }\end{array}$ & $\begin{array}{l}\text { Professional } \\
\text { Certification } \\
\text { within First 12 } \\
\text { Months }\end{array}$ & $\begin{array}{l}\text { Two Years or } \\
\text { More of } \\
\text { Inspection } \\
\text { Experience }\end{array}$ & $\begin{array}{l}\text { Knowledge of } \\
\text { Environmental } \\
\text { Laws }\end{array}$ \\
\hline City of San Jose & $\mathrm{X}$ & & $\mathrm{X}$ & $\mathrm{X}$ \\
\hline City of Oakland & $\mathrm{X}$ & & $\mathrm{X}$ & $\mathrm{X}$ \\
\hline City of Fremont & $\mathrm{X}$ & & $\mathrm{X}$ & \\
\hline City of Hayward & $\mathrm{X}$ & & $\mathrm{X}$ & $\mathrm{X}$ \\
\hline City of Sunnyvale & $\mathrm{X}$ & $\mathrm{X}$ & $\mathrm{X}$ \\
\hline City of Concord & & & $\mathrm{X}$ & \\
\hline City of Santa Clara & & $\mathrm{X}$ & $\mathrm{X}$ & \\
\hline City of Vallejo & & & $\mathrm{X}$ & $\mathrm{X}$ \\
\hline City of Berkeley & & & & \\
\hline City of Richmond & & & $\mathrm{X}$ & \\
\hline City of Daly City & & & & \\
\hline City of San Mateo & & & & \\
\hline $\begin{array}{l}\text { City of San } \\
\text { Leandro }\end{array}$ & & & & \\
\hline City of Livermore & & & & \\
\hline
\end{tabular}

Source: Berkeley, 2017; Concord, 2012; Daly City, 2007; Fremont, 2009; Hayward, 2015; Livermore, 2004; Oakland, 2014; Richmond, 2011; San Jose, 2001; San Leandro, 2015; San Mateo, 2002; Santa Clara, 2008; Sunnyvale, 2014; Vallejo, 2013 
Per the MRP, permittees conduct stormwater runoff quality inspections at construction sites that are one acre or more, or high priority sites. The criteria for high priority sites are based on slope percentage, geological maps, and hydromodifcation detail. Table 55 is a breakdown of the type of sites, and total amount of sites, per each city. Table 56 compares total number of sites to inspections and violations of each city.

Table 57 summarizes the two categories of Best Management Practices with the highest percentage of violations followed by the number of violations, and total violations. The City of Concord, San Leandro and San Mateo did not have enforcement violations for 2016. Sediment Control was the category with most violations for nine of the cities. Good Site Management was the other category with most violation for the remaining two cities, Vallejo and Daly City. The category with the second highest violations for most cities was Good Site Management, followed by Sediment Control.

Table 58 breaks down violations by enforcement level. The number of enforcements will not match the number of violations seen in Table 56 and Table 57 because of reporting procedures. Each city counts one violation in a category for each site and inspection regardless of how many violations or problems occurred in the BMP category. For example, if during an inspection at a site there were two Sediment Control violations, only one violation would be counted in the annual report and therefore this table. Each level varies from city to city. For most cities, Level 1 is a verbal notice or a correction notice. Level 2 is a written notice. Level 3 is a form of a citation or notice to comply in most cities. Level 4 is legal action and referral to the State. 
Table 55: Total Number of Sites

\begin{tabular}{|l|l|l|l|}
\hline $\begin{array}{l}\text { Summary of Sites That } \\
\text { Require Stormwater } \\
\text { Runoff Quality } \\
\text { Inspections }\end{array}$ & $\begin{array}{l}\text { Number of High } \\
\text { Priority Sites Less } \\
\text { Than an Acre }\end{array}$ & $\begin{array}{l}\text { Number of Sites } \\
\text { Disturbing More } \\
\text { Than One Acre }\end{array}$ & Total Sites \\
\hline City of San Jose & 30 & 104 & 143 \\
\hline City of Oakland & 0 & 6 & 6 \\
\hline City of Fremont & 2 & 44 & 46 \\
\hline City of Hayward & 2 & 16 & 18 \\
\hline City of Sunnyvale & 0 & 45 & 45 \\
\hline City of Concord & 0 & 11 & 11 \\
\hline City of Santa Clara & 1 & 33 & 34 \\
\hline City of Vallejo & 0 & 9 & 9 \\
\hline City of Berkeley & 39 & 1 & 40 \\
\hline City of Richmond & 2 & 9 & 11 \\
\hline City of Daly City & 0 & 5 & 5 \\
\hline City of San Mateo & 0 & 11 & 11 \\
\hline City of San Leandro & 0 & 4 & 4 \\
\hline City of Livermore & 0 & 11 & 11 \\
\hline Source: Berkeley; Con & & & 0 \\
\hline
\end{tabular}

Source: Berkeley; Concord; Daly City; Fremont; Hayward; Livermore; Oakland; Richmond; San Jose; San Leandro; San Mateo; Santa Clara; Sunnyvale; Vallejo; 2016 
Table 56: Comparison of Sites to Inspections and Violations

\begin{tabular}{|l|l|l|l|}
\hline $\begin{array}{l}\text { Summary of Sites, } \\
\text { Inspections and } \\
\text { Violations }\end{array}$ & $\begin{array}{l}\text { Total Number of } \\
\text { Sites }\end{array}$ & $\begin{array}{l}\text { Total Number of } \\
\text { Stormwater Runoff } \\
\text { Quality Inspections } \\
\text { Conducted }\end{array}$ & $\begin{array}{l}\text { Total Number of } \\
\text { Storm Water } \\
\text { Violations }\end{array}$ \\
\hline City of San Jose & 143 & 1352 & 331 \\
\hline City of Oakland & 6 & 67 & 12 \\
\hline City of Fremont & 46 & 365 & 202 \\
\hline City Of Hayward & 18 & 101 & 3 \\
\hline City of Sunnyvale & 45 & 364 & 66 \\
\hline City of Concord & 11 & 60 & 0 \\
\hline City of Santa Clara & 34 & 272 & 177 \\
\hline City of Vallejo & 9 & 99 & 18 \\
\hline City of Berkeley & 40 & 215 & 4 \\
\hline City of Richmond & 11 & 100 & 3 \\
\hline City of Daly City & 5 & 35 & 3 \\
\hline City of San Mateo & 11 & 77 & 0 \\
\hline $\begin{array}{l}\text { City of San } \\
\text { Leandro }\end{array}$ & 4 & 17 & 0 \\
\hline City of Livermore & 11 & 70 & 29 \\
\hline Source: Berkeley; & Cond $;$ Daly City; & & \\
\hline
\end{tabular}

Source: Berkeley; Concord; Daly City; Fremont; Hayward; Livermore; Oakland; Richmond;

San Jose; San Leandro; San Mateo; Santa Clara; Sunnyvale; Vallejo; 2016 
Table 57: Summary of Categories with Most Violations

\begin{tabular}{|c|c|c|c|c|c|}
\hline $\begin{array}{l}\text { Summary of } \\
\text { Inspection } \\
\text { Violations }\end{array}$ & $\begin{array}{l}\text { Category With } \\
\text { Highest } \\
\text { Percentage of } \\
\text { Violations }\end{array}$ & $\begin{array}{l}\text { Number of } \\
\text { Violations in } \\
\text { Category } \\
\text { with Highest } \\
\text { Percentage }\end{array}$ & $\begin{array}{l}\text { Category with } \\
\text { Second Highest } \\
\text { Percentage of } \\
\text { Violations }\end{array}$ & $\begin{array}{l}\text { Number of } \\
\text { Violations in } \\
\text { Category } \\
\text { with Second } \\
\text { Highest } \\
\text { percentage }\end{array}$ & $\begin{array}{l}\text { Total of } \\
\text { All } \\
\text { Violations }\end{array}$ \\
\hline $\begin{array}{l}\text { City of San } \\
\text { Jose }\end{array}$ & $\begin{array}{l}\text { Sediment } \\
\text { Control }\end{array}$ & 169 & $\begin{array}{l}\text { Good Site } \\
\text { Management }\end{array}$ & 133 & 331 \\
\hline $\begin{array}{l}\text { City of } \\
\text { Oakland }\end{array}$ & $\begin{array}{l}\text { Sediment } \\
\text { Control }\end{array}$ & 4 & Erosion Control & 4 & 12 \\
\hline City of Fremont & $\begin{array}{l}\text { Sediment } \\
\text { Control }\end{array}$ & 72 & $\begin{array}{l}\text { Good Site } \\
\text { Management }\end{array}$ & 60 & 202 \\
\hline $\begin{array}{l}\text { City of } \\
\text { Hayward }\end{array}$ & $\begin{array}{l}\text { Sediment } \\
\text { Control }\end{array}$ & 2 & $\begin{array}{l}\text { Run On \& Run } \\
\text { Off Control }\end{array}$ & 1 & 3 \\
\hline $\begin{array}{l}\text { City of } \\
\text { Sunnyvale }\end{array}$ & $\begin{array}{l}\text { Sediment } \\
\text { Control }\end{array}$ & 56 & $\begin{array}{l}\text { Good Site } \\
\text { Management }\end{array}$ & 8 & 66 \\
\hline $\begin{array}{l}\text { City of } \\
\text { Concord }\end{array}$ & $\mathrm{N} / \mathrm{A}$ & 0 & $\mathrm{~N} / \mathrm{A}$ & 0 & 0 \\
\hline $\begin{array}{l}\text { City of Santa } \\
\text { Clara }\end{array}$ & $\begin{array}{l}\text { Sediment } \\
\text { Control }\end{array}$ & 69 & $\begin{array}{l}\text { Good Site } \\
\text { Management }\end{array}$ & 54 & 177 \\
\hline City of Vallejo & $\begin{array}{l}\text { Good Site } \\
\text { Management }\end{array}$ & 11 & Sediment Control & 7 & 18 \\
\hline $\begin{array}{l}\text { City of } \\
\text { Berkeley }\end{array}$ & $\begin{array}{l}\text { Sediment } \\
\text { Control }\end{array}$ & 2 & $\begin{array}{l}\text { Good Site } \\
\text { Management }\end{array}$ & 2 & 4 \\
\hline $\begin{array}{l}\text { City of } \\
\text { Richmond }\end{array}$ & $\begin{array}{l}\text { Sediment } \\
\text { Control }\end{array}$ & 1 & $\begin{array}{l}\text { Good Site } \\
\text { Management }\end{array}$ & 1 & 3 \\
\hline $\begin{array}{l}\text { City of Daly } \\
\text { City }\end{array}$ & $\begin{array}{l}\text { Good Site } \\
\text { Management }\end{array}$ & 2 & Sediment Control & 1 & 3 \\
\hline $\begin{array}{l}\text { City of San } \\
\text { Mateo }\end{array}$ & $\mathrm{N} / \mathrm{A}$ & 0 & $\mathrm{~N} / \mathrm{A}$ & 0 & 0 \\
\hline $\begin{array}{l}\text { City of San } \\
\text { Leandro }\end{array}$ & N/A & 0 & N/A & 0 & 0 \\
\hline $\begin{array}{l}\text { City of } \\
\text { Livermore }\end{array}$ & $\begin{array}{l}\text { Sediment } \\
\text { Control }\end{array}$ & 13 & $\begin{array}{l}\text { Good Site } \\
\text { Management }\end{array}$ & 8 & 29 \\
\hline
\end{tabular}

Source: Berkeley; Concord; Daly City; Fremont; Hayward; Livermore; Oakland; Richmond; San Jose; San Leandro; San Mateo; Santa Clara; Sunnyvale; Vallejo; 2016 
Table 58: Number of Construction Related Stormwater Enforcement Actions

\begin{tabular}{|l|l|l|l|l|l|}
\hline $\begin{array}{l}\text { Summary of } \\
\text { Enforcement Actions } \\
\text { Per Level }\end{array}$ & Level 1 & Level 2 & Level 4 & Level 5 & Total \\
\hline City of San Jose & 152 & 61 & 53 & 26 & 292 \\
\hline City of Oakland & 9 & 0 & 0 & 0 & 9 \\
\hline City of Fremont & 54 & 35 & 38 & 0 & 127 \\
\hline City of Hayward & 12 & 1 & 1 & 0 & 14 \\
\hline City of Sunnyvale & 53 & 2 & 0 & 0 & 55 \\
\hline City of Concord & 0 & 0 & 0 & 0 & 0 \\
\hline City of Santa Clara & 46 & 39 & 3 & 0 & 88 \\
\hline City of Vallejo & 51 & 20 & 0 & 0 & 71 \\
\hline City of Berkeley & 11 & 2 & 0 & 0 & 13 \\
\hline City of Richmond & 0 & 1 & 0 & 0 & 0 \\
\hline City of Daly City & 0 & 2 & 0 & 0 & 2 \\
\hline City of San Mateo & 0 & 0 & 0 & 0 & 0 \\
\hline City of San Leandro & 0 & 0 & 0 & 0 & 0 \\
\hline City of Livermore & 23 & 0 & 0 & 0 & 23 \\
\hline Source: Berkeley; Con & & 0 & 0 & 0 \\
\hline
\end{tabular}

Source: Berkeley; Concord; Daly City; Fremont; Hayward; Livermore; Oakland; Richmond; San Jose; San Leandro; San Mateo; Santa Clara; Sunnyvale; Vallejo; 2016 


\section{CONCLUSION}

This research focused on compliance with the MRP regarding construction site control Construction Inspection Programs. Requirements historically varied from permit to permit and have proved challenging for the Regional Water Quality Control Board to have a consistent means of evaluating. The fourteen cities studied for this research are all co-permittees under one regional permit and share requirements, which provided an opportunity to compare and evaluate their enforcement programs.

The main challenges cities are having regarding the Construction Inspection Programs are increasing requirements each year from the MRP, and lack of resources, such as funding and staff. Based on the answers to the city questionnaires, another challenge cities face is coordination between multiple departments and ensuring that MRP requirements are met.

Quality inspections conducted by quality inspectors, in addition to complying with MRP requirements, will prevent a situation such as unfolded in the City of San Diego. Cities are still tasked with conducting self-evaluations of their own Construction Inspection Programs. Great variance remains among the permittees with tracking procedures and training for staff. The Regional Water Quality Control Board should consider streamlining tracking procedures and training. 


\section{SOURCES}

Andreen, W.L. (2007). Motivating enforcement: Institutional culture and the Clean Water Act. Pace Environmental Law Review, 24, 67-77.

Brown, T.C., and Froemke, P. (2012). National assessments of nonpoint source threats to water quality. Oxford Journals BioScience, 62(2), 136-146.

Burby, R.J., and Paterson, R.G. (1993). Improving compliance with state environmental regulations. Journal of Policy Analysis and Management, 12(4), 753-772.

California Regional Water Quality Control Board. (2015). San Francisco Bay Region Municipal Regional Stormwater NPDES Permit. Order No. R2-2015-0049, NPDES Permit No. CAS612008, November 19, 2015.

California State Water Board. (2008). Overview of California Water Quality Law. Retrieved from https://www.waterboards.ca.gov/board_reference/docs/wq_law.pdf

California Stormwater Quality Association (CASQA). (2005). Stormwater Program Effectiveness Assessment Survey Summary Report. Retrieved from https://www.casqa.org/sites/default/files/effectiveness assessment/rl04 casqa_final_summary_report-effectiveness_assessment_survey_2005.pdf

Campbell, M. (2007). Achieving a successful storm water permit program in Oregon. Natural Resources \& Environment, 21(4), 39-44. Retrieved from http://www.jstor.org.libaccess.sjlibrary.org/stable/40924852

Charbeneau, R., \& Barrett, M. (1998). Evaluation of methods for estimating stormwater pollutant loads. Water Environment Research, 70(7), 1295-1302. Retrieved from http://www.jstor.org.libaccess.sjlibrary.org/stable/25045155 
City of Berkeley. (2017). Berkeley municipal code. Retrieved from http://www.codepublishing.com/CA/Berkeley/

City of Berkeley. (2016). City of Berkeley's annual report of fiscal year 2015-2016. Berkeley, CA: U.S.

City of Berkeley. (2013). City of Berkeley enforcement response plan. Berkeley, CA: U.S.

City of Berkeley. (2017). City of Berkeley engineering inspection. Berkeley, CA: U.S.

City of Concord. (2016). City of Concord annual report fiscal year 2015-2016. Concord, CA: U.S.

City of Concord. (2012). City of Concord construction inspector. Concord, CA: U.S.

City of Concord. (2010). City of Concord enforcement response plan. Concord, CA: U.S.

City of Concord. (2017). Concord municipal code. Retrieved from http://www.codepublishing.com/CA/Concord/

City of Daly City. (2016). City of Daly City fiscal year 2015/2016 annual report. Daly City, CA: U.S.

City of Daly City. (2017). City of Daly City code of ordinances. Retrieved at https://www.municode.com/library/ca/daly_city/codes/code_of_ordinances

City of Daly City. (2016). City of Daly City enforcement response plan. Daly City, CA: U.S. City of Daly City. (2007). City of Daly City public works inspector. Daly City, CA: U.S

City of Fremont. (2016). City of Fremont clean water program annual report for fiscal year 2015/2016. Fremont, CA: U.S.

City of Fremont. (2017). Fremont municipal code. Retrieved from http://www.codepublishing.com/CA/Fremont/ 
City of Fremont. (2013). City of Fremont enforcement response plan for the municipal stormwater plan. Fremont, CA: U.S.

City of Fremont. (2009). City of Fremont environmental specialist I. Fremont, CA: U.S.

City of Hayward. (2015). City of Hayward construction inspector. Hayward, CA: U.S.

City of Hayward. (2016). City of Hayward fiscal year 2015-2016 annual report of stormwater program implementation. Hayward, CA: U.S.

City of Hayward. (2017). Hayward, California- municipal code. Retrieved from https://www.municode.com/library/ca/hayward/codes/municipal_code

City of Hayward. (2016). City of Hayward stormwater enforcement response plan. Hayward, CA: U.S.

City of Livermore. (2010). City of Livermore enforcement response plan for the City of Livermore stormwater management and control program.

City of Livermore. (2016). City of Livermore fiscal year 2015-2016 annual report of stormwater program implementation. Livermore, CA: U.S.

City of Livermore. (2004). City of Livermore water resources source control inspector. Livermore, CA: U.S.

City of Livermore. (2017). Livermore municipal code. Retrieved from http://www.codepublishing.com/CA/Livermore/

City of Oakland. (2017). City of San Jose code of ordinances. Retrieved from https://www.municode.com/library/ca/oakland

City of Oakland. (2013). City of Oakland enforcement response plan. Oakland, CA: U.S. City of Oakland. (2014). City of Oakland environmental program specialist qualifications. Oakland, CA: U.S. 
City of Oakland. (2016). City of Oakland stormwater management annual report 2015-2016.

Oakland, CA: U.S.

City of Richmond. (2016). City of Richmond annual report fiscal year 2015-2016. Richmond, CA: U.S.

City of Richmond. (2017). City of Richmond California city council ordinances. Retrieved from http://www.ci.richmond.ca.us/archive.aspx?AMID=66\&Type=\&ADID $=$

City of Richmond. (2011). City of Richmond California source control inspector. Richmond, CA: U.S.

City of Richmond. (2016). City of Richmond enforcement response guide, Richmond, CA: U.S.

City of San Jose. (2013). Construction program enforcement response plan. San Jose, CA: US.

City of San Jose. (2001). City of San Jose environmental inspector I/II minimum qualifications. San Jose, CA: U.S.

City of San Jose. (2017). San Jose, California- code of ordinances. Retrieved from https://www.municode.com/library/ca/san jose/codes/code_of_ordinances

City of San Jose. (2016). City of San Jose stormwater management annual report 2015-2016. San Jose, CA: U.S.

City of San Leandro. (2016). City of San Leandro enforcement response plan. San Leandro, CA: U.S.

City of San Leandro. (2015). City of San Leandro environmental protection specialist I/II. San Leandro, CA: U.S.

City of San Leandro. (2016). City of San Leandro fiscal year 2015-2016 annual report of stormwater program implementation. San Leandro, CA: U.S. 
City of San Leandro. (2017). San Leandro municipal code. Retrieved at http://qcode.us/codes/sanleandro/

City of San Mateo. (2017). City of San Mateo construction inspector I/II. San Mateo, CA: U.S. City of San Mateo. (2017). City of San Mateo fiscal year 2015-2016 annual report of stormwater program implementation. San Mateo, CA: U.S.

City of San Mateo. (2017). City of San Mateo stormwater management and discharge control enforcement response plan.

City of San Mateo. (2017). San Mateo city charter and municipal code. Retrieved from http://qcode.us/codes/sanmateo/

City of Santa Clara. (2017). City of Santa Clara city code. Retrieved from http://www.codepublishing.com/CA/SantaClara/

City of Santa Clara. (2013). City of Santa Clara enforcement response plan. Santa Clara, CA: U.S.

City of Santa Clara. (2008). City of Santa Clara public works inspector. Santa Clara, CA: U.S. City of Santa Clara. (2016). City of Santa Clara urban runoff pollution program fiscal year 2015-16 annual report. Sunnyvale, CA: U.S.

City of Sunnyvale. (2013). City of Sunnyvale enforcement response plan. Sunnyvale, CA: U.S. City of Sunnyvale. (2014). City of Sunnyvale environmental compliance inspector. Sunnyvale, CA: U.S.

City of Sunnyvale. (2016). City of Sunnyvale stormwater management annual report fiscal year 2015-2016. Sunnyvale, CA: U.S.

City of Sunnyvale. (2016). Sunnyvale, California- municipal code. Retrieved from http://qcode.us/codes/sunnyvale/ 
City of Vallejo. (2016). City of Vallejo annual report fiscal year 2015-2016. Vallejo, CA: U.S.

City of Vallejo. (2015). City of Vallejo enforcement response guide. Vallejo, CA: U.S.

City of Vallejo. (2007). City of Vallejo engineering inspector. Vallejo, CA: U.S.

City of Vallejo. (2013). Vallejo municipal code. Retrieved from

http://www.ci.vallejo.ca.us/city_hall/departments_divisions/city_attorney/vallejo_muni cipal_code/

Craig, R.K. (2004). The Clean Water Act and the Constitution: Legal Structure and the Public's Right to a Clean and Healthy Environment. Washington DC: Environmental Law Institute.

Craig, R.K., and Roberts, A.M. (2015). When will government regulate nonpoint source pollution? A comparative perspective. Boston College Environmental Affairs Law Review, 42(1)24-61.

Envirocert. (2016). General Principles Review Manual. Marion, NC: Envirocert International.

Feldman, M., \& Mitchell, E. (2007). Storm Water Enforcement Response and Settlement Strategies. Natural Resources \& Environment, 21(4), 17-23. Retrieved from http://www.jstor.org.libaccess.sjlibrary.org/stable/40924848

Garvey, W. (1973). New York State's enforcement program. Journal (Water Pollution Control Federation), 45(10), 2072-2080. Retrieved from http://www.jstor.org.libaccess.sjlibrary.org/stable/25038006

James, L.A. (2003). Nonpoint source pollution and the Clean Water Act: Policy problems and professional prospects. University Council on Water Resources, 126, 60-67. 
Jolin, B., Knifton, M., \& Lowrey, B. (2007). State construction general permits for storm water discharges. Natural Resources \& Environment, 21(4), 24-29. Retrieved from http://www.jstor.org.libaccess.sjlibrary.org/stable/40924849

Kabler, L. (2007). EPA steps up compliance assistance and enforcement at construction sites. Natural Resources \& Environment, 21(4), 12-16. Retrieved from http://www.jstor.org.libaccess.sjlibrary.org/stable/40924847

Korpics, J. (1988). Regulation of storm water point source discharges. Journal (Water Pollution Control Federation), 60(1), 50-56. Retrieved from http://www.jstor.org.libaccess.sjlibrary.org/stable/25043457

James, L.A. (2003). Nonpoint source pollution and the Clean Water Act: Policy problems and professional prospects. University Council on Water Resources, 126, 60-67.

Kabler, L. (2007). EPA steps up compliance assistance and enforcement at construction sites. Natural Resources \& Environment, 21(4), 12-16.

Magat, W.A., and Viscusi,W.K. (1990). Effectiveness of the EPA's regulatory enforcement: The case of the industrial effluent standards. The Journal of Law \& Economics, 33(2), 331360.

Murchison, K.M. (2005). Learning from more than five-and-a-half decades of federal water pollution control legislation: Twenty lessons for the future. Boston College Environmental Affairs Law Review, 32, 527-598.

Pontius, F. (2008). Agencies boost enforcement of construction site stormwater rules. Journal of American Water Works Association, 14-21.

Shimshack, J.P. (2009). The Performance of the Clean Water Act Monitoring and Enforcement. 
Sylvia, R.D., and Sylvia, K.M. (2012). Program Planning and Evaluation for the Public Manager. Long Grove, IL: Waveland Press, Inc.

Water Environment Federation. (1997). The Clean Water Act 25 $5^{\text {th }}$ Anniversary Edition.

Alexandria, VA: Water Environment Federation.

White, S.S., and Boswell, M. R. (2006). Planning for water quality: Implementation for the NPDES phase II stormwater program in California and Kansas. Journal of Environmental Planning and Management, 49(1), 141-160.

White, S.S., and Boswell, M. R. (2007). Stormwater quality and local government innovation. Journal of the American Planning, 73(2), 185-193. 